\title{
ASUNTOS EXTERIORES, DERECHO INTERNACIONAL Y EL NUEVO FEDERALISMO: LECCIONES DERIVADAS DE LA COORDINACIÓN*
}

\author{
ROBERT B. AHDIEH \\ Profesor Visitante de la Columbia Law School. Director del Centro de Estudios \\ de Federalismo y de Gobernanza Intersistémica Emory Law School
}

\author{
SUMARIO \\ I. Asuntos exteriores, derecho internacional \\ y el nuevo federalismo. \\ II. Desde la coerción a la voz: derecho in- \\ ternacional, coordinación nacional e in- \\ tervención subnacional. \\ III. La nueva coordinación. \\ IV. La gobernanza intersistémica de las rela- \\ ciones subnacionales, nacionales e in- \\ ternacionales. \\ V. El tiempo, el lugar y los límites de la \\ gobernanza intersistémica. \\ VI. Conclusiones.
}

Con un poco del arte de la escena, por el que es igualmente conocido, el gobernador Arnold Schwarzenegger ${ }^{1}$ ha llevado al escenario al Estado de California, como si fuera una encarnación actual de las antiguas ciudades-

\footnotetext{
* Traducción de M. SALVADOR MARTínEZ y S. SÁNCHEZ GONZÁLEZ, Profesores Titulares de Derecho Constitucional de la UNED. Trabajo publicado originalmente en la revista Missouri Law Review, en el número 73, de 2008. Los traductores han decidido mantener el sistema de citas en las notas a pie que utilizó el autor en la publicación original del trabajo.

1 "Creo que juntos no sólo podemos llevar a California hacia el futuro... podemos mostrar a la nación y al mundo cómo hacerlo. Lo podemos hacer porque disponemos de la potencia económica, de la población y de la fuerza tecnológica de una nación-estado. Somos el equivalente moderno de las antiguas ciudades-estado de Atenas y de Esparta. California tiene las ideas de Atenas y el poder de Esparta" (Arnold Schwarzenegger, Gobernador del Estado de California, Discurso sobre el estado de la nación, 9 de enero de 2007). Transcripción disponible en http:// gov.ca.gov/press-release/5089/.
}

UNED. Teoría y Realidad Constitucional, núm. 24, 2009, pp. 109-172. 
estado de Atenas y Esparta. Más teatral incluso ha sido, sin embargo, el modo en que el Estado ha tratado de hacer buena su retórica. En medio de la atención general prestada a la manipulación por parte de los aseguradores de las demandas de las victimas del Holocausto a finales de los años 90, California aprobó una legislación que ordenaba la revelación de todas las medidas políticas potencialmente relacionadas con cualquier empresa que pretendiera hacer negocios en el Estado ${ }^{2}$. Con los mismos efectos, a la vista de la falta de acción federal ante al genocidio que se estaba produciendo en Darfur, el legislativo californiano modificó la normativa en 2006 para facilitar la enajenación de los fondos de pensiones del Estado para cualquier inversión asociada con Sudan ${ }^{3}$. En fin, para afrontar la crisis del cambio climático —el asunto en el que este Estado se ha comprometido más en el ámbito de las relaciones exteriores y el derecho internacional- California se ha unido a varias provincias de Canadá, la Unión Europea, Francia, Alemania, Nueva Zelanda, Noruega, el Reino Unido y a otros países, para establecer la Asociación para la Acción Internacional sobre el Carbón, un grupo cuyo fin es promover un régimen "cap-and-trade"* para las emisiones de carbón ${ }^{4}$. California, sin embargo, no ha estado sola en su compromiso con el mundo. Concretamente en el problema del cambio climático, varios Estados federados y entes locales de todo el país han discutido, promovido, e incluso adoptado normas internacionales, han tratado de coordinar líneas de acción con sus correspondientes en el extranjero y han emprendido acciones para afrontar el cambio climático5.

En las páginas siguientes analizaremos a través del prisma de la coordinación las implicaciones de tal compromiso subnacional en materia de relaciones exteriores y derecho internacional. Lo que la explicación dominante de la relación entre instituciones e intereses subnacionales, nacionales e internacionales percibe, es un régimen nacional de federalismo dual en un orden de Estados tipo Westfalia. Esto exige un tipo particular de coordinación, en el que la ejecución efectiva de las normas legales internacionales (es decir, el deseo de lo que denominaríamos "coordinación externamente dirigida") establece la imposición de estándares nacionales sobre las autoridades subnacionales (es decir, un modelo de "coordinación dirigida internamente").

2 Cfr. Am. Ins. Ass'n v. Garamendi, 539 U.S. 396 (2003).

3 Vid. la California Sudan Act, CAL. GOV'T Code $\$ 7513.6$ (West 2008) (added by 2006 Cal. Stat. ch. 442).

* N. del T.: "Cap-and trade" es un sistema de fijación de límites máximos de emisión (de carbono) y de negociación de los derechos de emisión entre empresas, de manera que aquéllas que necesiten emitir una cantidad de carbono superior a lo establecido, tendrán que adquirir créditos —o "allowances" — de las que emitan menos o por debajo de su límite.

4 Vid. Judith RESNIK, Joshua CIVIL \& Joseph FRUEH, Ratifying Kyoto at the Local Level: Sovereigntism, Federalism, and Transnational Organizations of Government Actors (TOGAs), Ariz. L. Rev. 709 (2008).

5 Vid. Judith RESNIK, Foreign and domestic Affairs: Rethinking Horizontal Federalism and Foreign Affairs Preemprion in Light of Translocal Internationalism, 57 Emory L. J. 31, 62 (2007). Además de California, de hecho, otros Estados participan también en la Asociación para la Acción sobre el Carbón. 
En esta explicación dominante de la coordinación en las relaciones subnacionales, nacionales e internacionales destacan dos dimensiones. La primera es la naturaleza central del gobierno nacional ${ }^{6}$. La nación está, literalmente, en el centro de la ecuación: en su búsqueda de coordinación externa, la nación impone la coordinación interna. Igualmente relevante para este análisis es una segunda dimensión, relativa a la dirección del compromiso de los intereses e instituciones sub e inter-nacionales. De manera implícita, en la explicación dominante de la coordinación de las relaciones sub-e internacionales, la influencia y la autoridad discurren desde esta última esfera a la primera. Los intereses en juego y las preferencias tienen su origen en el plano internacional y, (a través del poder nacional), se transmiten sin ser cuestionados al nivel subnacional y no viceversa.

De estas dimensiones más conceptuales de la arquitectura de la coordinación en las relaciones subnacionales, nacionales e internacionales, se desprenden dos suposiciones básicas en el estudio de los asuntos exteriores y el derecho internacional. Ambas, en un sentido, cabe decir, hablan con las voces que se oyen (y que no se oyen) en la interacción entre las instituciones subnacionales, nacionales e internacionales. En principio, un compromiso efectivo en los asuntos exteriores, se dice, exige que una nación hable con una sola voz de escala nacional. Al tiempo, se entiende de manera generalizada que el Derecho Internacional silencie (o al menos, descarte) las voces subnacionales. Lo que exponemos a continuación, en el fondo, es una tentativa de cuestionar esas pretensiones reiteradas sobre la voz en las relaciones subnacionales, nacionales e internacionales.

Con ese propósito, este artículo estudia la dinámica de la coordinación subnacional, nacional e internacional en nuestros días ${ }^{7}$. Para empezar, apuntamos que la parte - la mitad - internamente dirigida, de la explicación convencional de la coordinación — la coordinación nacional de los actores subnacionales, al servicio de necesidades internacionales - resulta cada vez más inapropiada. Los Estados federados y también otras entidades político-territoriales internas se relacionan con autoridades foráneas y se involucran de manera creciente en cuestiones internacionales. La mitad de la ecuación dirigida externamente — que es necesaria una sola voz nacional para la coordinación - es igualmente cuestionable en lo que se refiere tanto a la bibliografía teórica sobre la coordinación, las redes y el establecimiento de estándares, como a los recientes modelos de lo que denominare-

6 En cierto sentido esta característica puede entenderse como la esencia del sistema de Westfalia. Vid. Robert A. SHAPIRO, Federalism as Intersystemic Governance: Legitimacy in a PostWestphalian World, 57 Emory L.J. 115, 122-23 (2007).

7 Aunque nos servimos de las lecciones proporcionadas por la teoría de los juegos, no ponemos el énfasis en los modelos concretos de la interacción estratégica definidos por los juegos de coordinación. Cfr. Thomas C. SCHELLING, The Strategy of Conflict 54-55 (2nd ed.1980); Robert B. AHDIEH, Law's signal: A Cueing Theory of Law in Market Transition, 77 S. Cal. L. Rev. 215, 234-238 (2004). Tal y como lo utilizamos aquí, el término 'coordinación' tiene un significado más amplio. 
mos "coordinación horizontal" entre actores subnacionales. La coordinación de Estados federados y autoridades locales con sus equivalentes foráneos y nacionales en materia de compromisos en cuestiones internacionales es cada vez mayor.

Así pues, la iniciativa de los gobiernos de los Estados federados y de los entes locales en asuntos internacionales representa, por lo tanto, un desafío notable a nuestras explicaciones convencionales de los asuntos exteriores y el derecho internacional. En primer lugar, desmiente la idea de que éstos son en la práctica exclusivamente un asunto nacional. En segundo término, debilita las afirmaciones que sostienen que la exclusividad es necesaria si se quiere evitar el caos. La coordinación dirigida internamente por las autoridades nacionales, por lo tanto, es cada vez de menor relevancia en el campo de los asuntos exteriores y del derecho internacional. Lo cual no conlleva un declive de la coordinación dirigida externamente. Esta coordinación simplemente adopta una forma diferente.

Lo expuesto hasta aquí apunta las líneas preliminares de una explicación distinta de la relación entre las instituciones e intereses subnacionales, nacionales e internacionales. En términos más amplios, puede entenderse que la relación se sitúa en algún lugar entre la dinámica convencional de la jerarquía, que va desde la esfera internacional a la subnacional vía autoridad nacional, y la amenazante alternativa de una des-coordinación descentralizada en asuntos exteriores y derecho internacional. En este sentido, puede representar una tercera vía, en la cual el solapamiento y la interdependencia alimenten un potencial de cara a un compromiso, aprendizaje y coordinación en la materia ${ }^{8}$. Por lo tanto, al explorar la dinámica cambiante de la coordinación transnacional, podremos empezar a delinear una nueva explicación de las relaciones subnacionales, nacionales e internacionales?.

8 A este respecto, el análisis que realizamos aquí se hace eco en aspectos importantes de la bibliografía sobre "la nueva gobernanza", ejemplificada en la obra de Mike DORF y Chuck SABEL, Brad KARKKAINEN, Orly LOBEL, Joanne SCOTT y Gráinne DE BÚRCA y Bill SIMON, entre otros. Vid., p. ej., Law and new governance in the Eu and the Us (Gráinne DE BÚRCA \& Joanne SCOTT eds., 2006); Michael C. DORF \& Charles F. SABEL, A Constitution of Democratic Experimentalism, 98 Colum. L. Rev. 267 (1998); Bradley C. KARKKAINEN, InformationForcing Environmental Regulation, 33 Fla. St. U.L. Rev. 861 (2006); Orly LOBEL, The Renew Deal: The Fall of Regulation and the Rise of Governance in Contemporary Legal Thought, 89 Minn. L. Rev. 342 (2004); Charles F. SABEL \& William H. SIMON, Destabilization Rights: How Public Law Litigation Succeeds, 117 Harv. L. Rev. 1015 (2004). Igualmente evoca la aspiración fundamental del "proceso legal transnacional...de apoderar a un mayor número de actores para que participen", de Harold KOH. Harold HONGJU KOH, Why Do Nations Obey Internacional Law? 106 Yale L. J. 2599, 2656 (1997).

9 El modelo descrito - de intervención subnacional en la creación, evolución e incorporación de las normas internacionales - tiene implicaciones significativas para las críticas del derecho internacional fundadas en la soberanía y la democracia. Como ha sostenido Judith Resnik, si la incorporación de las normas internacionales se produce por la vía de la acción legislativa y ejecutiva, como suele ocurrir en los ámbitos estatal y local, es totalmente democrática. Vid. Judith RESNIK, Law as Affiliation: "Foreign"Law, Democratic Federalism, and the Sovereigntism of the Nation-State, Int'l J. Const. L., 33, 53 (2008). Por otro lado, como nace de la iniciativa de las ramas políticas a nivel subnacional, es igualmente congruente con las demandas del federalismo. 
En el epígrafe 1 de la Parte I, describimos sucesivamente la revolución del federalismo en los últimos años, la intervención creciente de las autoridades subnacionales en los asuntos exteriores y en el derecho internacional, y los consecuentes cambios en la dinámica del federalismo en esas áreas. Luego, en dos secciones, continúa el núcleo de nuestro análisis — de las dimensiones gemelas de la coordinación descritas anteriormente. En la Parte II se estudian las formas en que la intervención subnacional creciente mina la noción convencional de derecho internacional que entiende a éstas como voces subnacionales silenciadas ${ }^{10}$. Más que ahogar las voces subnacionales, el derecho internacional puede precisamente hacer lo contrario y crear oportunidades para que sean oídos los Estados federados y los entes locales. La Parte III pone el énfasis en las redes de Estados federados y entes locales que coordinan cada vez más las intervenciones subnacionales en asuntos exteriores. Partiendo del análisis de los procedimientos de establecimiento de estándares y redes, destaca que tal coordinación horizontal puede actuar como un sustituto efectivo de los modelos tradicionales de coordinación centralizada (es decir, a nivel nacional) en materia de asuntos exteriores.

Las dos secciones finales dan un paso atrás desde las cuestiones inmediatas de los asuntos exteriores y el derecho internacional, y ofrecen una explicación amplia de las relaciones de los intereses e instituciones subnacionales, nacionales e internacionales. En la Parte IV tratamos de describir un régimen de "gobernanza inter-sistémica" como posible marco para el análisis de esa cambiante relación. A continuación, mostramos los elementos centrales de tal régimen, apuntamos las contribuciones de las autoridades nacionales dentro de él, y consideramos cómo es y cómo podría ser mediante varios ejemplos concretos de gobernanza multi-nivel. En la Parte $\mathrm{V}$ avanzamos en nuestro análisis y estudiamos la atracción normativa de tales pautas de interacción "inter-sistémica", las indicaciones posibles y las contraindicaciones de su aplicabilidad y probable eficacia, y los límites resultantes de su uso.

En aspectos importantes, la doctrina jurídica ha matizado poco cuando ha pretendido dar debida cuenta de la gobernanza, tanto a nivel internacional como subnacional. En el primero, se ha tendido a centrarse abiertamente en la cuestión de lo que se ha percibido como una falta de autoridad y de jerarquía "legales" en la gobernanza internacional ${ }^{11}$. En cuanto al ámbito subnacional, simplemente no le hemos prestado atención. Frente a estas tendencias, lo que aquí se expone representa un esfuerzo de integración de la gobernanza internacional y subnacional en una imagen común y colectiva

Ibid. La integración creciente del derecho internacional a través de la iniciativa subnacional debilita, así, a buena parte de la crítica "nacionalista" realizada por Jack Goldsmith, Curt BRADLEY y otros. Vid., p. ej., Curtis A. BRADLEY \& Jack L. GOLDSMITH, Customary Internacional Lawas Federal Common Law: A Critique of the Modern Position, 110 Har. L. Rev. 815 (1997).

10 Cfr. RESNIK, supra nota 5, en pág. 35.

11 Vid. Paul SCHIFF BERMAN, Global Legal Pluralism, 80 S. Cal. L. Rev. 1155, 1177 (2007). 
—incluso coordinada- de la interacción entre los intereses y las instituciones subnacionales, nacionales e internacionales ${ }^{12}$.

\section{ASUNTOS EXTERIORES, DERECHO INTERNACIONAL Y EL NUEVO FEDERALISMO}

Durante los últimos años hemos visto el avance progresivo de la revolución del federalismo iniciada, en primer lugar, por el Tribunal Supremo a principios de los años noventa. Recientemente, de hecho, el federalismo incluso ha comenzado a jugar un papel en las esferas tradicionales de los asuntos exteriores y del derecho internacional. Hemos presenciado una intervención creciente de las autoridades subnacionales en esta esfera. Sin embargo, con la referencia de diseños similares del "nuevo federalismo" en otros ámbitos, esta intervención subnacional se ha caracterizado por cierta concurrencia entre la participación estatal y federal.

\section{I.1. La Revolución del Federalismo}

En el otoño de 1994, durante el primer semestre en la Facultad de Derecho, se nos enseñó pronto que el federalismo había muerto. Aprendimos que, en la América actual, los Estados federados ya no constituían una fuente de identidad significativa, ni disponían de un poder real. Su "Soberanía" nominal no debería ser entendida en modo alguno como un límite a la autoridad federal — constitucional o política- Se planteó, es cierto, el problema del caso New York $v$. United States ${ }^{13}$. En él, el Tribunal Supremo había anulado algunas disposiciones de la Ley Federal sobre Política de Residuos Radiactivos de Bajo Nivel por su "[disposición de] los gobiernos de los Estados con fines reguladores federales ${ }^{\prime 14}$. Pero el caso New York fue la excepción singular que confirmaba la regla.

Al final de mi primer año, sin embargo, todo eso había cambiado ${ }^{15}$. El 26 de abril de 1995, el Tribunal Supremo hizo pública la decisión en el caso

12 Hay que subrayar que este análisis pretende aclarar la dinámica cambiante del federalismo norteamericano. Los aspectos de economía política que exponemos más abajo pueden existir (como algo descriptivo) o ser útiles (como algo normativo) también en otros ámbitos jurisdiccionales. Con ese ánimo, sugerimos diversos símiles foráneos y transnacionales de las pautas de interacción nacional que describimos. Proceder así no significa, sin embargo, apuntar que la dinámica institucional que aquí se esboza muestre modelos de gobernanza multi-nivel en todos los Estados federales.

13505 U.S. 144 (1992)

14 Id. en pág. 175. Podría traerse a colación el caso Gregory v. Ashcroft, 501 U.S. 452 (1991), como el primer indicio del cambio que a la larga se produjo.

15 Quizás, proporcionando una extraña suerte de apoyo a la vieja y reiterada pretensión de que la Facultad de Derecho de Yale no enseña Derecho. Vid., p. ej., Royce DE ROHAN BARONDES, Want Your Opinions Questioned or Reversed? Hire a Yale Clerk (And Don't Require de Bar), (3 de abril de 2008), disponible en http://ssrn.com/abstract=1116343 (borrador en el archivo con el autor). 
United States $v$. Lopez, en la que anulaba la Ley sobre Zonas Escolares Libres de Armas, porque el Congreso no había justificado constitucionalmente la medida legislativa de acuerdo con la Cláusula de Comercio*16. Aunque no era totalmente una base sin precedentes para derogar una norma federal, con anterioridad al caso López no se había oído hablar de la Cláusula de Comercio durante sesenta años ${ }^{17}$. Sin embargo, durante los últimos años en la Facultad de Derecho se dictaron varias resoluciones del mismo tenor, como fueron Seminole Tribe of Florida $v$. Florida, sobre la base de la Enmienda Undécima ${ }^{18}$, City of Boerne v. Flores, de la Enmienda Catorce ${ }^{19}$, y Printz $v$. United States, de la Enmienda Décima ${ }^{20}$. La revolución del federalismo no se detuvo ahí, sino que continuó con una serie de decisiones adicionales en años posteriores - en Alden v. Maine ${ }^{21}$, Kimel v. Florida Board of Regents ${ }^{22}$ y Board of Trustees of the University of Alabama $v$. Garret ${ }^{23}-\mathrm{y}$ una ulterior decisión sobre la base de la Cláusula de Comercio - United States v. Morrison ${ }^{24}$.

Además, el renacimiento del federalismo en Estados Unidos no se ha limitado al ámbito judicial. Más bien, el discurso revitalizado del federalismo se ha convertido en una característica principal de la política norteamericana. Los candidatos a cargos electivos, en particular entre los republicanos, se han visto obligados a atender las demandas de federalismo. El federalismo, por otra parte, se utiliza para atacar o defender la legislación del Congreso.

Pero, a decir verdad, no se ha observado una gran coherencia en esta afición renovada por el federalismo. El Tribunal Supremo no ha vacilado en respaldar sorprendentemente demandas de un derecho preferencial* de compra federal ${ }^{25}$. Ni se ha abstenido de interpretaciones amplias de la Cláusula

\footnotetext{
* N. del T.: La denominada Cláusula de Comercio está recogida en el artículo I, sección 8. 3. de la Constitución norteamericana, y dispone que «El Congreso tendrá competencia (...) para regular el comercio (...) entre los Estados".

16514 U.S. 549 (1995).

17 El Tribunal Supremo no había anulado legislación federal invocando la Cláusula de Comercio desde su fallo en A.L.A. Schechter Poultry Corp. v. United States, 295 U.S. 495 (1935).

18517 U.S. 44 (1996).

19521 U.S. 507 (1997).

20521 U.S. 898 (1997).

21527 U.S. 706 (1999).

22528 U.S. $62(2000)$.

23531 U.S. 356 (2001).

24529 U.S. 598 (2000).

* N. del T.: "Preemption", en el original.

25 Vid., p. ej., Geier v. Am. Honda Motor Co., 529 U.S. 861 (2000). Robert SCHAPIRO ha cuestionado la percepción convencional de la incoherencia en la jurisprudencia del Tribunal y ha ofrecido un análisis distinto - y una reconciliación- de sus resoluciones sobre federalismo y derechos preferentes de compra. Vid. Robert A. SCHAPIRO, Toward a Theory of Interactive Federalism, 91, Iowa L. Rev. 243 (2005). En ambas categorías, mantiene, hay que interpretar que el Tribunal defiende una atribución "federalista dual" de jurisdicción no exclusiva y no superpuesta, sea a los Estados (en los casos del Tribunal sobre federalismo), sea al gobierno federal (en sus casos sobre derechos preferentes de compra). Vid. Id. en pág. 247-48.
} 
de Comercio Durmiente ${ }^{26}$, de las limitaciones derivadas del debido proceso legal al reconocimiento estatal de daños punitivos ${ }^{27}$, de la doctrina de las expropiaciones reguladas ${ }^{*}{ }^{28}$ incluso de la Cláusula de la Protección Igual, en el caso sui generis de Bush v. Gore. ${ }^{29}$ El Congreso, al mismo tiempo, ha aceptado la progresiva federalización del derecho penal, ${ }^{30}$ se ha apropiado del derecho estatal sobre valores y títulos ${ }^{31}$ y — quizás y para mayor asombroha privado de competencia a los tribunales estatales en un buen número de asuntos derivados de demandas presentadas por grupos ${ }^{32}$. La tendencia general de los últimos veinte años es, sin embargo, bastante clara. La revolución del federalismo ha seguido su marcha hacia delante.

\section{2. Voces nuevas en Asuntos Exteriores y en Derecho Internacional}

El avance de la revolución del federalismo se ha manifestado en particular en el campo de los asuntos exteriores y del derecho internacional, lo cual, incluso bajo estándares revolucionarios, representa un cambio notable. Estamos hablando — con cierta cautela - de áreas especialmente aisladas frente a la participación subnacional ${ }^{33}$. Si ha habido un campo propio de la autoridad nacional de manera clara y exclusiva, es precisamente éste. Pues bien, incluso aquí hay signos de que el nuevo federalismo está interviniendo.

Los trabajos académicos parecen haber dado algún paso en esa dirección, incluso en sus debates sobre la naturaleza del derecho consuetudinario internacional (DCI). Los expertos revisionistas, como Curt Bradley y Jack Goldsmith ${ }^{34}$ han puesto en tela de juicio recientemente la visión tradicional del DCI como un derecho común federal. Basándose en sus análisis, entre otras cosas, en las demandas de federalismo, los revisionistas arguyen que los tribunales federales no deberían aplicar el DCI sin contar con la autorización de los poderes políticos o sin la incorporación del DCI al derecho de los Estados federados. Los que mantienen la postura tradicional, por su parte, han respondido con convicción, poniendo en cuestión los análisis teóricos e históricos que subyacen a la opinión revisionista, e insistiendo en la concepción

26 Vid., p. ej., Camps Newfound Owatonna, Inc. v. Town of Harrison, 520 U.S. 564, 571 (1997); W. Lynn Creamery, Inc. v. Healy, 512 U.S. 186, 201 (1994).

27 Vid., p. ej., State Farm Mut. Auto. Ins. Co. v. Campbell, 538 U.S. 408 (2003).

* N. del T.: "Regulatory takings", en el original.

28 Vid., p. ej., Dolan v. City of Tigard, 512 U.S. 374 (1994).

29 Vid. 531 U.S. 98 (2000) (per curiam).

$30 \mathrm{Vid}$. Rachel E. BARKOW, Separation of Powers and the Criminal Law, 58 Stan. L. Rev. 989, 1018-19 (2006) ("La jurisdicción federal penal continúa expandiéndose a marchas forzadas.").

31 Vid., p. ej., Securities Litigation Uniform Standards Act of 1998, Pub. L. No. 105-353, 112 Stat. 3227 (codificada como modificada en secciones dispersas del U.S.C. 15).

32 Vid. Class action Fairness Act of 2005, Pub. L. No. 109-2, 119 Stat (codificada como modificada en varias secciones del U.S.C. 28).

33 Vid., p. ej., las notas 117 a 129 y el texto que les acompaña.

34 Vid., p. ej., BRADLEY \& GOLDSMITH, supra nota 9. 
del derecho consuetudinario internacional como preventivo de cualquier derecho estatal incompatible, conforme a la Cláusula de Supremacía*35. El debate sobre la naturaleza del DCI continúa hoy en día, y en la actualidad el Tribunal Supremo le ha prestado también atención ${ }^{36}$.

Los últimos años, sin embargo, ofrecen una demostración más explícita de la creciente importancia del federalismo en materia de asuntos exteriores. Un primer ejemplo viene del Congreso. Ante las violaciones que se estaban cometiendo contra los derechos humanos en el Sudán, perpetradas, al menos, ante la indiferencia del gobierno sudanés, si no ante su bendición y apoyo $^{37}$, la Asamblea Norteamericana de entes locales y Estados federados, incluyendo Arizona, California, Illinois, Louisiana y New Jersey, entre otras autoridades subnacionales, adoptaron varias medidas para sancionar y condenar al gobierno sudanés ${ }^{38}$. Entre ellas, Illinois aprobó normas especialmente duras, incluyendo una serie de disposiciones confiscatorias que prohibían al Tesoro y al Fondo de Pensiones del Estado invertir en: (1) entidades asociadas al gobierno de Sudán, (2) sociedades que hicieran negocios en Sudán, o (3) bancos que no impusieran requisitos informativos de los solicitantes de préstamos relativos a sus relaciones con el gobierno sudanés ${ }^{39}$. Sirviéndose de la resolución recaída en el caso Crosby v. Nacional Foreign Trade Coun$\mathrm{cil}^{40}$ —en el que el Tribunal Supremo anuló la normativa de Massachussets que prohibía a entes estatales la adquisición de bienes y servicios de empresas que hicieran negocios en Birmania- el Consejo Nacional de Comercio Exterior recurrió contra la Ley de Illinois y se aseguró una decisión favorable del Tribunal de Distrito del Distrito Norte de Illinois ${ }^{41}$.

Más notable fue lo que ocurrió después: con la presión de los representantes de Illinois en el Senado, el 31 de diciembre del 2007, el Congreso aprobó la Ley de Responsabilidad y Confiscación de Sudán (SADA) ${ }^{42}$. En

* N. del T.: La Cláusula de Supremacía se incluyó en el artículo VI de la Constitución y estableció la supremacía del derecho nacional sobre el derecho de los Estados miembros siempre que el gobierno nacional actuase dentro de los límites constitucionales.

35 Vid., p. ej., Harold HONGJU KOH, Is Internacional Law Really State Law? 111 Harv. L. Rev. 1824 (1998).

36 Vid., p. ej., Sosa v. Alvarez-Machain, 542 U.S. 692 (2004); vid. también Curtis A.BRADLEY, Jack L. GOLDSMITH \& David H. MOORE, Sosa, Customary Internacional Law, and the Continuing Relevance of Erie, 120 Harv. L. Rev. 869 (2007).

37 Vid. Human rights watch, darfur documents confirm government policy of militia support (2004), htpp://hrw.org/backgrounder/africa/072004darfur.pdf.

$38 \mathrm{Vid}$. Resoluciones adoptadas por la Asamblea norteamericana de alcaldes (2007), disponible en http://www.usmayors.org/75th AnnualMeeting/resolutions_full.pdf; John B. REYNOLDS, III \& Maureen E. THORSON, California, Illinois and Other Status Have Sudan Divestment Legislation: What Do You Need to Know? (Oct. 5, 2006), http://ww.wileyrein.com/publication. cfm?pf=1\&publication_id=12782.

39 Ley para poner fin a las atrocidades y el terrorismo en Sudán, III. Pub. Act 94-0079, junio $27,2005$.

40530 U.S. 363 (2000).

41 Nat'l Foreign Trade Council v. Giannoulias, 523 F.Supp. 2d 731 (N.D. III. 2007).

42 Sudan Accountability and Divestment Act (SADA) of 2007, Pub. L. No. 110-174, 121 Stat. 2516. 
marcado contraste con regímenes de sanciones pasados, la SADA autoriza medidas estatales y locales confiscatorias contra el Sudán. "[Un] gobierno estatal o local puede adoptar y hacer cumplir medidas... para privar de fondos del gobierno estatal o local, o prohibir la inversión de activos del gobierno estatal o local en personas que el gobierno estatal o local determine... (y que) estén llevando o tengan inversiones directas en operaciones comerciales» en el Sudán ${ }^{43}$. De esta forma, el Congreso abrió la puerta a la intervención estatal y local en justo el tipo de temas de asuntos exteriores que, según se ha reivindicado normalmente, caen bajo la órbita del gobierno federal - como una cuestión de necesidad- ${ }^{44}$.

Unos meses después, el Tribunal Supremo entró en escena con motivo de su decisión en el litigio Medellin v. Texas ${ }^{45}$. El problema en este caso afectaba al cumplimiento de una orden emanada del Tribunal Internacional de Justicia (TIJ) en Avena and Other Mexican Nationals, referente a los derechos de la Convención de Viena de un grupo de mejicanos condenados a muerte en varios procesos penales seguidos en ciertos Estados de los Estados Uni$\operatorname{dos}^{46}$. En concreto el TIJ se había dirigido a los Estados Unidos para que "revisase y reconsiderase las declaraciones de culpabilidad y las sentencias de los nacionales mejicanos", sin referirse a un determinado defecto procesal derivado de la omisión de plantear sus pretensiones basadas en la Convención de Viena en tiempo hábil ${ }^{47}$. Dada la condena de los mejicanos en un tribunal estatal (de un Estado federado), el análisis en el caso Medellín se centró en si la respuesta de Estados Unidos al TIJ podía realizarla el Presidente - tal como pretendió con una nota enviada a los tribunales de los Estados para que cumplieran con la decisión - o debía dejarse a la determinación de los Estados $^{48}$. En lo que hace a esta cuestión, el Tribunal Supremo

43 Id. \3(b). Al firmar la norma, el Presidente añadió lo que ha sido considerado como una afirmación peculiar dado el contexto. Afirmó: "Esta Ley pretende autorizar a los gobiernos estatal y local para que impidan a las empresas hacer negocios en los sectores citados en el Sudán y, así, eliminar el riesgo de que se interpreten como aisladas de la abstención federal, aquellas acciones de confiscación estatales y locales que pudieran interferir en la ejecución de la politica exterior nacional. Sin embargo, puesto que la Constitución otorga la autoridad exclusiva de dirigir las relaciones internacionales al Gobierno Federal, el poder ejecutivo interpretará y hará cumplir esta norma de manera que no entre en conflicto con el citado Gobierno". Manifestación aneja a la firma de la Sudan Accountability and Divestment Act (SADA), de 2007, 43 Weekly comp. press. doc. 1646 (31 de diciembre de 2007). Dada la autorización legal explícita de la acción estatal y local, el único significado plausible de la declaración del Presidente sería que dispone del poder de prevalecer sobre la voluntad del Congreso a la hora de establecer una política sancionadora del Sudán.

44 Vid., p. ej., Am. Ins. Ass'n v. Garamendi, 539 U.S. 396, 493-24 (2003); Crosby, 530 U.S. en 381 (apuntando la necesidad de que el Presidente "hable en nombre de la Nación con una sola voz al tratar con otros gobiernos").

45128 S.Ct. 1346 (2008).

46 Id. en pág. 1353; Vid. Case Concerning Avena and Other Mexican Nationals (Mex. V. U.S.), 2004 I.C.J. (Tribunal Internacional de Justicia) 12 (Mar 31).

47 Avena, 2004, I.C.J., en pág. 72.

48 Después de que el Tribunal Supremo otorgase el 'certiorari', pero antes de la vista oral, el Presidente dictó un "Memorándum para el Fiscal General", titulado "Cumplimiento de la Decisión 
decidió a favor del Estado de Tejas que «ni Avena, ni el Memorándum del Presidente constituyen derecho federal directamente aplicable que impida limitaciones estatales en la presentación de peticiones de "habeas" sucesivas" ${ }^{49}$. Al fallar así, el Tribunal no discutió que «la resolución del TIJ en Avena crease una obligación de derecho internacional para los Estados Unidos ${ }^{50}$. Sin embargo, a falta de una acción conjunta de los poderes federales ejecutivo y legislativo, no competía a los tribunales federales cumplir con esa obligación ${ }^{51}$.

Partiendo de esta conclusión, cabe entender que el Tribunal aprobó que el Estado de Tejas - y, en general, los otros Estados- asumieran la importante función de determinar la naturaleza y alcance del cumplimiento por parte de los Estados Unidos de sus obligaciones bajo la Convención de Vie$n^{52}$. En su voto concurrente con la opinión del Tribunal el magistrado Stevens lo subrayó en términos que merecen citarse extensamente:

"Bajo los términos expresos de la Cláusula de Supremacía, la obligación de los Estados Unidos de "comprometerse a cumplir" las decisiones del TIJ recae tanto en cada uno de los Estados como del Gobierno Federal. Una consecuencia de nuestra forma de gobierno es que a veces los Estados deben cargar con la responsabilidad de proteger el honor e integridad de la Nación. La obligación de Tejas a este respecto es mayor porque fue Tejas

del Tribunal Internacional de Justicia en Avena" que decía: "He decidido, en virtud de la autoridad que me ha sido otorgada como Presidente por la Constitución y por las leyes de los Estados Unidos de América, que los Estados Unidos asuman sus obligaciones internacionales bajo la resolución del Tribunal Internacional de Justicia en [Avena], ordenando que los Tribunales de los Estados ejecuten la resolución, de acuerdo con los principios generales de cortesía en los juicios presentados por los 51 mejicanos referidos en dicha resolución." Medellín, 128 S.Ct. en pág. 1355.

$49 I d$., en pág. 1353.

50 Id., en pág. 1367.

51 Importa destacar que el Tribunal no cuestionó la capacidad del Congreso y del Presidente, actuando conjuntamente, para imponer su criterio sobre las autoridades estatales. Que no se haya emprendido tal acción conjunta hasta ese punto, ni haya sido tomada desde la resolución, apoya, sin embargo, la interpretación de Medellín que hacemos — en la que el Estado de Tejas es central para el cumplimiento de la resolución del TIJ. Las implicaciones de Medellín, como tal, pueden razonablemente entenderse tanto en relación con la cuestión vertical del federalismo, como con la horizontal de la separación de poderes.

52 La pauta de las interacciones institucionales seguida en el primero (de los diversos) encuentros entre el TS de Estados Unidos y el TIJ relativos a la Convención de Viena sobre Relaciones Consulares, en Breard v. Greene, 523 U.S. 371 (1998) puede verse como un anuncio del papel central asignado al Estado de Tejas por la decisión del TS en Medellin. En Breard, el Tribunal afrontó el problema de emitir una orden judicial solicitada por el TIJ para permitirle proseguir con la revisión del caso. En contra de algunas opiniones, el Tribunal se negó a expedir una orden, y el Tribunal de Virginia continuó con la ejecución y desestimó las peticiones personales del Secretario de Estado norteamericano al gobernador de Virginia para que se aplazase la ejecución de Breard. Vid. William J. ACEVES, Application of the Viena Convention on Consular Relations (Paraguay v. United status) —Provisional Measures Order, Breard v.Greene, 92 Am. J. Int'l L. 517 (1998). Como a Tejas en Medellin, se puede decir que a Virginia se le ha dado voz en Breard. 
- por no proporcionar el informe consular de conformidad con la Convención de Viena-, el Estado que implicó a los Estados Unidos en la actual disputa. Si Tejas es responsable de la ruptura de un tratado por parte de los Estados Unidos, a Tejas le incumbe impedir la ruptura de otro,"53.

En un grado creciente, los episodios de intervención subnacional en asuntos exteriores y en derecho internacional, similares a los de SADA y Medellín, no son excepciones sino la norma ${ }^{54}$. Piénsese, como ejemplo adicional, la intervención extensiva de las autoridades subnacionales en las iniciativas foráneas e internacionales relativas al cambio climático. Más de ochocientos alcaldes, que representan a cerca de ochenta millones de norteamericanos, han apoyado el Protocolo de Kyoto ${ }^{55}$. A nivel estatal, diez Estados federados se han unido a las provincias canadienses de Columbia Británica y Manitoba, la Comisión Europea, algunos países europeos individualmente considerados y Nueva Zelanda, para promover iniciativas de limitación de emisiones y negociación ("cap-and-trade") trasnacionales. Otros ocho Estados se unieron con varias provincias de Canadá para firmar el Acuerdo de los Grandes Lagos ${ }^{56}$.

El cambio climático no es lo único. Efectos análogos ha tenido la respuesta local y estatal ante el hecho de que Estados Unidos no ratificara la Convención sobre la Eliminación de todas las formas de Discriminación contra la Mujer (Convention on the Elimination of All Forms of Discrimination Against Women - CEDAW-). En 2004, cuarenta y cuatro ciudades norteamericanas, dieciocho condados y dieciséis Estados, habían considerado o aprobado legislación relacionada con la CEDAW. Algunas jurisdicciones de ámbito municipal han llegado incluso a aplicar sus disposiciones como si fueran derecho local ${ }^{57}$.

53 Medellin, 128 S.Ct. 1374 (voto concurrente de Stevens).

54 Cfr. Julian G. KU Gubernatorial Foreign Policy, Yale. L. J. 2380, 2383 (2006) (que apunta el nacimiento de iniciativas en política exterior emprendidas por miembros del poder ejecutivo del Estado). Señalar esto no significa negar la presencia de tendencias de signo contrario. La articulación del Tribunal Supremo de la asunción expansiva de los asuntos exteriores - a la que SADA puede interpretarse como una respuesta- no se produjo hasta el año 2000. Vid. Crosby v. Nat'l Foreign Trade Council, 530 U.S. 363 (2000). Incluso más recientemente, en el año 2003, el fallo del Tribunal Supremo en el litigio American Insurance Ass'n v. Garamendi, 539 U.S. 396 (2003) nos ofreció una explicación expansiva del poder federal en el campo de los asuntos exteriores, en la que se veía significativamente restringida la acción del gobierno subnacional. A la larga, la cuestión empírica - que resulta temprano resolver- es si los datos que estamos destacando aquí representan una tendencia, o una desviación temporal de la norma sempiterna de una autoridad nacional fuerte en asuntos exteriores y en derecho internacional. Dado el amplio contexto descrito más arriba, me inclino por lo primero. No dudamos, sin embargo, de que, imparcialmente, se puede disentir.

55 Vid. RESNIK, CIVIL \& FRUEH, supra nota 4, en pág. 718-719.

56 Cfr. id., en pág. 719-20.

57 Cfr. Catherine POWELL, Dialogic Federalism: Constitucional Posibilitéis for Incorporation of Human Rights Law in the United Status, 150 U. PA. L. Rev. 245 (2001); Vid. también RESNIK, CIVIN \& FRUEH, supra nota 4, en pág. 724. Un ejemplo peculiar reciente de iniciativa subnacional en el campo de los asuntos exteriores, fue la decisión de la Universidad de Massachussets de privar a Robert Mugabe, que acababa de lograr prorrogar su mandato por medios violentos, del título honorario que le había concedido años antes. Vid. Peter SCHWORM, UMass Voids Honor Awarded to Mugabe, Boston Globe, 13 de junio de 2008, en pág. 4. 
En un número creciente de casos, la participación estatal y local va más allá de la política "simbólica" — rúbrica bajo la cual se despacha con frecuencia la intervención subnacional en asuntos exteriores- ${ }^{58}$. La adopción de la CEDAW en el derecho local es un ejemplo. Las medidas de expropiación dirigidas contra Sudán son igualmente significativas. Asimismo, algunos de los compromisos estatales y locales asumidos en el terreno del cambio climático. Ciertamente las medidas simbólicas también son comunes. Además, frente a la significación tradicional, no carecen de fuerza y significado59. Cada vez más, las iniciativas subnacionales de interés aquí incluidas van más allá de la retórica y repercuten en la política real.

No pretendemos sugerir que las pautas de intervención subnacional subrayadas representen un cambio total, irreversible o sin precedentes ${ }^{60}$. La tendencia no ha alcanzado todavía el nivel de un cambio estructural; sigue siendo contingente. Para la doctrina, por lo tanto, la posición dominante del gobierno federal en materia de asuntos exteriores y derecho internacional continúa inalterada. Así lo garantiza la Cláusula de Supremacía ${ }^{61}$. Incluso en los dos ejemplos citados aquí — la SADA y la sentencia del Tribunal Supremo en el caso Medellin - las instituciones de nivel nacional fueron en última instancia responsables de la creación de un espacio para que se emprendiera una iniciativa subnacional en el asunto ${ }^{62}$. Aun más, uno podría ofrecer expli-

58 Cfr. Robert STUMBERG, Preemption \& Human Rights: Local Options Alter Crosby v. Nftc, 32 Law \& Pol'y Int'l Bus. 109, 157 (2000)

59 Cfr. Richard H. MCADAMS, An Attitudinal Theory of Expressive Law, 79 Or. L. Rev. 339 (2000); Cass R. SUNSTEIN, On the Expressive Function of Law, 144 U. Pa. L. Rev. 2021, 2022-24, 2045 (1996).

60 Para empezar, existe un precedente del tipo de intervención subnacional sobre el que estamos llamando la atención. Vid. en general Julian G. KU, The State of New Cork Does Exist: How the Status Control Compliance with International Law, 82 N. C. L. Rev. 457 (2004). Con más perspectiva, es posible ver en las inveteradas normas para la aplicación de las sentencias foráneas una historia de la intervención subnacional en el ámbito internacional. La cuestión crítica, sin embargo, es si tales ocasiones para intervenir son de más alcance y, quizás incluso, si están apareciendo como una tendencia de mayor calado.

$61 \mathrm{Vid}$. U.S. Const. Art. VI, cl. 2 ("Esta Constitución y las Leyes de los Estados Unidos que en su virtud se aprueben... serán la Ley Suprema del País;... aun cuando hubiese alguna disposición contraria en la Constitución o en las Leyes de los Estados.").

62 Por separado, podría argüirse que deberíamos distinguir un caso de otro, puesto que en el de SADA fueron los poderes políticos federales los que fomentaron la iniciativa subnacional, mientras que en el de Medellín, el poder ejecutivo trató de constreñirla (con el Memorándum del Presidente). Vid. supra notas 43-44, 48-49 y el texto que las acompaña. Tal separación de lo que hemos denominado como nivel "nacional" de gobierno (y también de intereses e instituciones subnacionales e internacionales) es, seguramente un elemento útil de análisis. Cfr. Duncan B. HOLLIS, Executive Federalism: Forging New Federalist Constraints on the Treaty Power, 79 S. Cal. L.Rev. 1327 (2006) (analizando el fenómeno claro del "federalismo ejecutivo"); KU, supra nota 54, en pág. 2384 (ocupándose en una segregación análoga en el estudio de la política exterior "gubernamental"). Sin embargo, dado el propósito actual de analizar las implicaciones de la iniciativa subnacional en asuntos exteriores y derecho internacional, el análisis realizado aquí presenta el nivel nacional de gobierno en términos unitarios, que comprenda ambas, la sanción de los poderes políticos de la actividad subnacional en SADA y la sanción de la misma por el Tribunal Supremo en Medellin. 
caciones totalmente diferentes de cada ejemplo. Medellin podría interpretarse como un caso de distribución horizontal de poder entre las ramas ejecutiva y legislativa, más que como de distribución vertical entre los gobiernos federal y estatal $^{63}$. La Ley SADA, mientras tanto, podría presentarse como un caso de elusión del Congreso, en lugar de un caso de apoderamiento de los Estados y entidades locales ${ }^{64}$. Finalmente, cabría citar un número de ejemplos de signo contrario a SADA y Medellín. Considérense las sentencias algo anteriores dictadas en los casos Crosby v. National Foreign Trade Council ${ }^{65}$ y American Insurance Ass'n v. Garamendi ${ }^{66}$, que apuntan justamente en la dirección opuesta ${ }^{67}$.

Admitimos que buena parte de lo anterior contiene importantes advertencias para nuestro análisis. De otro lado, la afirmación de que en asuntos exteriores y en derecho internacional continúa el predominio federal parece excesiva. Esa afirmación, en el fondo, define el grado de poder nacional frente al poder subnacional en relación con el alcance de las cuestiones en las que las autoridades federales podrían imponer su voluntad. Si tal es la medida que cuenta, sin embargo, podría argüirse que vastos campos del derecho norteamericano - al menos además de la criminalización de la posesión de armas cerca de las escuelas (per United States $v$. Lopez) y de la imposición de responsabilidad civil por la violencia doméstica (per United States $v$. Morrison) - deberían entenderse como "federales" por naturaleza ${ }^{68}$. Si la

63 Vid. supra nota 51. Además, la interacción de Tejas con las normas internacionales en Medellín puede, también, expresarse de formas distintas. Nosotros la formulamos como una manifestación de voz estatal, con Tejas apoderado para decidir cómo aplicar la sentencia del Tribunal Internacional de Justicia. A la inversa, se podría hacer hincapié en la decisión de Tejas para fundamentalmente rechazar cualquier aplicabilidad del derecho internacional a su decisión. Destacamos la primera explicación, dado que nuestro análisis no se refiere tanto a la promoción y el progreso del derecho internacional, como a la participación estatal y local. Así, cabe considerar la intervención de Tejas sobre el fondo del asunto como normativamente interesante o carente de interés. Nuestro énfasis, sin embargo, recae sobre el procedimiento y sobre la intervención-injerencia subnacional en el mismo. Vid. infra la Parte V. A.

64 Por otra parte, hubiera bastado que el Congreso impusiera sus propias medidas a medias contra Sudán para inclinar la balanza del lado, de la inacción. En cambio, con la ley SADA, dio un paso decisivo, sin precedentes, de sanción explícita de la iniciativa estatal y local. Es esto último, creemos, lo que posee un significado real. Que las iniciativas de interés estatales y locales en el caso predataban la adopción de la SADA aparentemente servirían de apoyo a una explicación, más próxima a la nuestra, de iniciativa, influencia, e incluso de poder estatal y local genuinos.

65530 U.S. 363 (2000).

66539 U.S. 396 (2003).

67 Desde luego, los hechos subyacentes que precipitaron Crosby y Garamendi, en la medida en se oponen a la doctrina basada en los fundamentos de los casos, apoya nuestra interpretación de la creciente intervención estatal y local en los asuntos exteriores y en el derecho internacional. El hecho de que los Estados y las entidades locales hayan persistido en esa intervención incluso después de esas sentencias, y de que hayan comenzado a recibir apoyo por proseguir en esa dirección, puede considerarse como una prueba todavía mejor de la propuesta según la cual la intervención subnacional está en alza y cada vez es más aceptada.

68 Con ánimo similar, Mark ROE nos ha ofrecido una explicación del derecho de sociedades como esencialmente federal, dada la competencia del gobierno federal de ejercitar su derecho de preferencia sobre cualquier norma estatal de gobierno corporativo a la que ponga reparos. 
respuesta a mi énfasis en la participación creciente de los Estados y de las entidades locales en asuntos exteriores es que el gobierno federal todavía tiene la última palabra, el derecho estatal parece mucho más irrelevante. Si añadimos la aparente autorización derivada del caso Missouri v. Holland's de cualquier legislación federal adoptada en virtud en un tratado vinculante ${ }^{69}$, de hecho la irrelevancia del derecho estatal resulta aún mayor — -ihasta incluyendo la posesión de armas en zonas escolares y la violencia domésticaj-. Esto obviamente está pasando por alto algo sobre la naturaleza de la autoridad estatal frente a la federal.

Así, nuestro análisis de la creciente intervención subnacional en los asuntos exteriores va más allá de la autoridad de la doctrina sobre esa intervención. A pesar de Missouri $v$. Holland's y del todavía increíble alcance expansivo de la Cláusula de Comercio, los Estados indudablemente existen en la economía política de los Estados Unidos ${ }^{70}$. Y es igualmente en esta esfera de nuestra economía política moderna donde debería evaluarse la intervención local y estatal en los asuntos exteriores. De un lado a otro de numerosas áreas del derecho, algo ha cambiado en la interacción entre las instituciones e intereses subnacionales e internacionales en comparación con lo que ocurría hace una o dos décadas. Esto último no puede explicarlo la doctrina, que ha cambiado, si lo ha hecho solo en algunos aspectos. Pero indudablemente algo ha cambiado.

Esta intervención estatal y local en asuntos exteriores y en derecho internacional puede no representar todavía una transformación total. Pero sí representa un cambio - no en primer lugar en la doctrina, sino en la realidad de la gobernanza- Tal cambio no es irreversible, ni tampoco es inevitable algún cambio ulterior. Es, sin embargo, una posibilidad en una forma diferente de lo que tradicionalmente ha sido. Llegados a cierto punto, por otra parte, cabe esperar que sea difícil deshacer ese cambio. Una vez que los Estados

Vid. Mark J. ROE, Delaware's Competition, 117 Har. L. Rev. 588, 601 (2003). Merece citarse extensamente: "Imaginemos que el derecho societario consiste en cuatro normas de estructura 'sino'. Delaware decide si o no a las cuatro. Dos - de promedio- se aprueban como querian las autoridades federales. Una, les disgusta y la rechazan. Y la cuarta, las autoridades federales la encuentran objetable pero tolerable (o las autoridades están divididas), y la dejan. Entonces lo que resta en Delaware es lo que place a, o es tolerado por, las autoridades federales. Incluso sin reaccionar estratégicamente a la amenaza federal, todo el derecho societario de Delaware en este escenario es principalmente lo que desearian las autoridades federales, aunque sea Delaware quien nominalmente redacte la mayoría de las normas. Un observador de la situación descrita diría que el derecho de sociedades es en un 75\% estatal (o un 100\% porque la parte federal se define como un asunto externo a la sociedad y por lo tanto no vital para el derecho estatal de sociedades). En su lugar, nos permitimos sugerir que en ese contexto el derecho de sociedades es federal hasta un 87,5\% (un 25\% que las autoridades federales asumen directamente; un 50\% de las dos normas que examinan, les complacen y aceptan; y un 12\% de dividir la que estiman indiferente). El Estado de Delaware escribe las palabras, pero sólo en la medida en que las autoridades federales toleran el guión". Id.

69 Vid. infra y el texto adjunto.

70 En contra del criterio del Tribunal Supremo expresado en United States v. Belmont, 301 U.S. 324, 331 (1937), según el cual "respecto de todas las negociaciones y acuerdos internacionales, y de nuestras relaciones exteriores en general...el Estado de New York no existe". 
federados y las entidades locales posean una voz real en los asuntos exteriores y en la elaboración del derecho internacional, la economía política del federalismo nacional — si no necesariamente la doctrina constitucional- puede difícilmente hacer que se la silencie ${ }^{71}$.

\section{I.3. El nuevo Federalismo en Asuntos Exteriores Y DERECHO INTERNACIONAL}

Al evaluar las implicaciones de lo expuesto para la relación de los intereses e instituciones subnacionales, nacionales e internacionales, el primer paso es apreciar la naturaleza cambiante del federalismo nacional. El caso Missouri $v$. Holland - básico como es para el análisis que aquí hacemosnos ofrece un punto de partida muy útil ${ }^{72}$. En Holland, el Tribunal Supremo consideró la constitucionalidad de la legislación federal reguladora de la caza de pájaros migratorios. En los tribunales inferiores una legislación similar había sido directamente anulada por caer fuera del ámbito de los poderes que la Cláusula de Comercio otorga al gobierno federal ${ }^{73}$. Ante el Tribunal, sin embargo, el problema era que el Congreso trataba de evitar esa limitación constitucional ratificando un tratado que requería que los Estados Unidos adoptasen precisamente esa legislación. Enfrentada con la cuestión de si los Estados Unidos podrían "Violar" los límites constitucionales del federalismo basándose en la potestad de firmar tratados internacionales, el Tribunal —a través del Juez Colmes- sostuvo que sí podía ${ }^{74}$.

71 Una advertencia final: No tratamos de pintar de color de rosa la intervención de los Estados y las entidades locales en los asuntos exteriores y en el derecho internacional. Las opiniones que aquellos propugnan no serán probablemente siempre las que cualquier observador considerará atractivas. Judith Resnik apunta, a título de ejemplo, a los esfuerzos estatales y locales de promoción de la Enmienda Bricker anti-foránea y de fomento de la resistencia tenaz a la de-segregación. Vid. RESNIK supra nota 5, en pág. 89-90.

72252 U.S. 416 (1920). La sentencia del Tribunal en Holland ha sido el centro de atención de una vibrante bibliografía del federalismo de los asuntos exteriores. Vid., p. ej., Curtis A. BRADLEY, The Treaty Power and American Federalism, 97 Mich. L. Rev. 390 (1998); David. M. GOLOVE, Treaty-Making and the Nation: The Historical Foundations of the Nationalist Conception of the Treaty Power, 98 Mich. L. Rev. 1075 (2000); Nicholas QUINN ROSENKRANZ, Executing the Treaty Power, 118 Harv. L. Rev 1867 (2005); Peter J. SPIRO, Treaties, International Law and Constitutional Rights, 55 Stan L. Rev. 1999 (2003); Edward T. SWAINE, Does Federalism Constrain the Treaty Power?, 103 Colum. L. Rev. 403 (2003); Carlos Manuel VÁZQUEZ, Treaties and the Eleventh Amendment, 42 Va. J. Int'l. L. 713 (2002); vid. también Lori FISLER DAMROSCH, The Role of the United States Senate Concerning "Self-Executing "and "Non-Self-Executing" Treaties, 67 Chi.-Kent L. Rev. 515 (1991); David SLOSS, International Agreements and the Political Safeguards of Federalism, 55 Stan. L. Rev.1963 (2003). El abanico fascinante de cuestiones doctrinales que rodean Holland no es, sin embargo, el objeto del presente análisis.

73 En esos tribunales, la caza misma se interpretaba como una actividad puramente intraestatal, incluso si los pájaros podían cruzar las fronteras del Estado. Como tal, la Cláusula de Comercio fue considerada pertinente.

74 Holland, 252 U.S, en 433. Como dijo el Juez Homes: "Las Leyes del Congreso son la ley suprema del país solamente cuando se han elaborado de acuerdo con la Constitución, mientras 
Debería interpretarse que Holland deriva de forma natural de las ideas de federalismo dominantes en el tiempo de la sentencia. En el año 1920 prevalecía en la teoría y en la práctica el marco conceptual del "federalismo dual". Desde esa perspectiva, se entendía que los gobiernos federal y estatales gozaban de "esferas de autoridad exclusivas que no se solapaban" "75. Por lo que respecta a determinadas materias, se apoderaba a los Estados para que dictasen normas, pero no al gobierno federal; en otras, en cambio, mientras que el gobierno central disponía de un margen para actuar, los Estados carecían de competencia. Dentro de este paradigma, lo básico era definir los límites del Estado federado frente a la autoridad federal. Así, en el diseño del federalismo dual la tarea central es la del establecimiento de líneas delimitadoras $^{76}$.

En términos generales, un dualismo de tal naturaleza parece reflejar en un sentido visceral un proyecto jurídico de categorización, definiciones claras, y señalamiento de líneas divisorias ${ }^{77}$. El Juez del Tribunal Supremo A. Scalia ha hablado del "Rule of Law" como un "Law of Rules" ${ }^{78}$ La sentencia en el caso New Cork $v$. United States", con su insistencia en la delimitación clara de la responsabilidad federal y estatal, fue motivada por ideas similares ${ }^{79}$. Según esta interpretación, el Derecho sirve como un instrumento de claridad y certeza ${ }^{80}$.

que los tratados lo son cuando se han suscrito bajo la autoridad de los Estados Unidos. Existen dudas de si la autoridad de los Estados Unidos significa más que los actos formales prescritos para hacer el acuerdo. No queremos decir que no existan detalles en el poder de firmar tratados, pero deben determinarse de forma diferente. Id.

75 Vid. SCHAPIRO, supra nota 25, en pág. 246; Vid. también Robert POST, Federalism in the Taft Court Era: Can It Be revived»?, 51 Duke L. J. 1513, 1526-37 (2002). Pero, vid. Judith RESNIK, The Internationalism of American Federalism: Missouri and Holland, 73 Mo.L.Rev. 1105 (2008) (apuntando la referencia del Tribunal en Holland a una decisión correspondiente a un periodo anterior, en Carey v. South Dakota, 250 U.S. 118 (1919), como una sugerencia de la aceptación de la autoridad concurrente del Estado sobre la caza de aves migratorias).

76 Vid. SCHAPIRO, supra nota 25, en pág. 246; vid. también Daniel HALBERSTAM, Of Power and Responsability: The Political Morality of Federal Systems, 90 Va. L. Rev. 731, 820 (2004) ("La tendencia dominante en la jurisprudencia norteamericana ha sido considerar los proyectos de gobernanza federal y estatal como distintos esencialmente y tratar de resolver los conflictos intergubernamentales estableciendo fronteras claras entre los dos").

77 Vid. Robert B. AHDIEH, Dialectical Regulation, 38 Conn. L. Rev. 863, 865-866 (2006); vid. también Carol M. ROSE, Crystals and Mud in property Law, 40 Stan. L. Rev. 577, 579-80 (1988) (donde señala la tendencia de la búsqueda de la claridad en el Derecho).

78 Vid. Antonin SCALIA, The Rule of Law as a Law of Rules, 56 U. Chi. L. Rev. 1175, 1187 (1989).

79505 U.S. 144, 168-69 (1992). En el mismo sentido, la sentencia en United States v. Morrison, 529 U.S. 598 (2000) insistía en la distinción prescrita constitucionalmente "entre lo que es verdaderamente nacional y lo que es verdaderamente local». Id. en pág. 617-18 (citando United States v. Lopez, 514 U.S. 549, 568 (1995)). En general Vid. RESNIK, supra nota 75; RESNIK, supra, nota 5.

80 En un sentido amplio, puede entenderse que el análisis aquí realizado pone en tela de juicio la orientación convencional del derecho y de su estudio a la claridad. Más bien, como en la polémica entre estándares y reglas, vid., p. ej. Duncan KENNEDY, Form and Substance in Private Law Adjudication, 89 Harv.L.Rev. 1685, 1710 (1976), nuestra argumentación se sirve de la ambigüedad y de la complejidad. Vid. AHDIEH, supra, nota 77; Rose, supra nota 77. 
Cualquiera que sea la utilidad que tal establecimiento de líneas delimitadoras pueda tener - en el ámbito del federalismo o en el del derecho en general-, ya no da cuenta de la naturaleza de la gobernanza en Estados Unidos. En un buen número de campos lo normal es ahora la concurrencia de las competencias estatal y federal ${ }^{81}$. Los casos de federalismo delegado — "delegated program" - en los que las autoridades reguladoras federales definen las metas perseguidas a través de iniciativas locales y estatales, no son ya la excepción, sino la regla ${ }^{82}$. El derecho del medio ambiente es el caso paradigmático de este modelo. Pero el solapamiento competencial es patente en todo el ordenamiento jurídico norteamericano. A pesar del esfuerzo por racionalizar el derecho societario frente al derecho de títulos valores como derecho estatal frente al derecho federal, el derecho en la práctica - y cada vez más en los libros- lo hace difícil ${ }^{83}$. El derecho de la educación, sobre todo después de la Ley para impedir el abandono de los niños — "No Child Left Bebind Act" - , es otro ejemplo de solapamiento ${ }^{84}$.

Si los casos de SADA y Medellín, como otros ejemplos citados antes, indican algo, es cada vez más plausible pensar que la dinámica del federalismo en materia de asuntos exteriores se mueve también siguiendo esa dirección. La participación subnacional no significa un desplazamiento de la autoridad nacional en asuntos exteriores, como resultaría de la orientación dualista hacia la exclusividad. Más bien, las voces locales y estatales que están apareciendo complementan el poder nacional, son una redundancia del mismo ${ }^{85}$.

A continuación vamos a estudiar los modelos de interacción subnacional, nacional e internacional desde la perspectiva de la "coordinación". Si dividimos la relación multi-nivel en dos diferentes vertientes, de "coordinación internamente dirigida" y "coordinación dirigida externamente", creemos que podremos hacernos una idea de la dinámica operativa subyacente. Para empezar, descubrimos la posibilidad de que el derecho internacional funcione de modo creciente como un medio para integrar voces adicionales -incluyendo las de los gobiernos locales y estatales- en un discurso transnacional.

81 Vid. SCHAPIRO, supra, nota 25, en pág. 246.

82 Vid. William B. BUZBEE, Assymmetrical Regulation:Risk, Preemption, and the Floor/Ceiling Distinction, 82, N.Y.U. L. Rev. 1547, 1565-66 (2007). BUZBEE estudia el intento reciente de desplazar esta norma mediante la aprobación de topes en lugar de bases reguladores federales. Vid id. Vid. también Anna WILDE MATHEWS et al., State, Federal Powers Collide, Wall St. J., 1 de feb. 2008, en A8.

83 Vid. Robert B. AHDIEH, From "Federalization" to "Mixed Governance" in Corporate Law: A Defense of Sarbanes-Oxley, 53 Buff. L. Rev. 721, 730-34 (2005).

84 No Child Left Behind Act, de 2001, Pub. L. N. ${ }^{\circ}$ 107-110, 115 Stat.1425 (2002) (codificada como modificada en secciones dispersas del 20 U.S.C.).

85 Entre la sentencia del Tribunal Supremo en Holland, en 1920, y los ejemplos recientes de SADA y Medellín, que destacamos aquí, pueden, desde luego, seleccionarse una historia y jurisprudencia relacionadas. Dado nuestro enfoque en la dinámica actual de la relación entre instituciones subnacionales, nacionales e internacionales, preferimos ignorarla. La evolución desde Holland hasta nuestros días merece con toda seguridad más atención y estudio. 
Frente a construcciones convencionales, entre tanto, la existencia de voces adicionales no necesariamente tiene que implicar algo para el grado de coherencia/coordinación en los asuntos exteriores de los Estados Unidos. La coordinación efectiva puede surgir incluso de un régimen nacional descentralizado; simplemente, se tratará de una coordinación de signo distinto.

\section{DESDE LA COERCIÓN A LA VOZ: DERECHO INTERNACIONAL, COORDINACIÓN NACIONAL E INTERVENCIÓN SUBNACIONAL}

¿Cuáles son las implicaciones de la intervención creciente de las autoridades subnacionales en los asuntos exteriores y en el derecho internacional para la sensación dominante de tensión y conflicto en la relación entre normas internacionales e intereses subnacionales? Para proceder a una evaluación correcta, es útil comenzar con el entendimiento convencional de la coordinación entre instituciones e intereses subnacionales, nacionales e internacionales, de la que surgen esas ideas de conflicto.

Como comúnmente se sabe, la coordinación dinámica en las relaciones subnacionales, nacionales e internacionales puede dividirse en dos dimensiones: la externa y la interna. Si comenzamos con la primera, el derecho internacional puede entenderse fundamentalmente como un mecanismo de "coordinación externamente dirigida". Y las normas internacionales -y las consiguientes relaciones exteriores-, como un medio de alinear la conducta pública, y, en última instancia, la privada, al otro lado de las fronteras nacionales. La intervención de una nación en materia de asuntos exteriores y derecho internacional está motivada, como tal, por los fines de la coordinación.

¿Cuál es el significado de adjudicar esta función de coordinación a las autoridades nacionales, como hace el federalismo dual? Para establecerlo, conviene separar los fines y los medios de la coordinación dinámica. Como hemos apuntado, la coordinación externamente dirigida puede interpretarse como el fin de la coordinación. Mediante sus compromisos exteriores, las autoridades nacionales tratan de coordinar la política con otras naciones. Por ejemplo, los esfuerzos transnacionales con objeto de armonizar los requisitos para la revelación de secretos a fin de estimular la inversión de capital en el mercado y la protección de los inversores nacionales sugieren este modelo ${ }^{86}$. Otros ejemplos son las normas reguladoras del ámbito financiero (incluyendo las de la banca $)^{87}$, las iniciativas sobre compartir información en varias áreas

86 Vid., p. ej., Allowing U.S. Issuers to Prepare Financial Statements in Accordance with International Financial Reporting Standards, Securities Act Release N. $33-8831$. Exchange Act Release N. ${ }^{\circ}$ 34-56217 (7 de agosto de 2007), disponible en http://sec.gov/rules/concept/2007/33-8831.pdf.

87 Vid. Cally JORDAN \& Giovanni MAJNONI, Financial Regulatory Harmonization and the Globalization of Finance (World Bank Policy Research, Working Paper N. ${ }^{2}$ 2919, 2002), disponible en: http://papers.ssrn.com/sol3/papers.cfm?abstract_id=343260. 
del derecho (incluyendo la ejecución del derecho penal), y las normas internacionales sobre propiedad intelectual ${ }^{88}$.

Si la coordinación dirigida externamente constituye el fin en asuntos exteriores y derecho internacional, la "coordinación dirigida internamente" puede considerarse como el medio operativo. La coordinación dirigida externamente se consigue, así, mediante cierta alineación (es decir, coordinación) también de las políticas internas ${ }^{89}$. En muchos casos - y quizás en la mayoría- lo que se espera de la función de coordinación externamente dirigida en materia de asuntos exteriores es la coordinación de reglas y estándares dentro de la nación en general, mas que la sola alineación de las políticas nacionales. Así los acuerdos bilaterales y multilaterales tratan también de vincular a las autoridades subnacionales ${ }^{90}$.

Pero tal compromiso no ha sido asegurado convencionalmente por las autoridades subnacionales directamente ${ }^{91}$. En su lugar, el medio preferido para lograr esos fines ha sido la coordinación internamente dirigida. Para coordinar efectivamente normas transnacionales, el régimen tradicional del federalismo dual hizo hincapié al mismo tiempo en la importancia de una sola voz encargada de expresar en el exterior la política de la nación y en la necesidad de apoderar al portavoz para imponer la citada política internamente. De ahí la atribución al gobierno nacional del poder para actuar en asuntos exteriores y en la creación de normas internacionales, y para vincular a las autoridades subnacionales con los compromisos resultantes. Así pues, en un régimen de federalismo dual los asuntos exteriores y el derecho internacional representan un mecanismo centralizado (es decir, nacional) de coordinación dirigida externa e internamente.

En el lenguaje común, sin embargo, la relación entre las normas internacionales y los intereses subnacionales no es meramente jerárquica, como implica la interpretación de la coordinación internamente dirigida que funcio-

88 En la regulación de la propiedad intelectual internacional, el Agreement on Trade-Related Aspects of Intellectual Property Rights (TRIPs), 33 I.L.M. 1125, 1197 (15 de abril de 1994), puede entenderse como un proyecto de establecimiento de estándares.

89 Los acuerdos internacionales de comercio pueden ser indicativos, en la confianza de que los compromisos de las autoridades nacionales asegurarán el acceso a mercados que de otra manera serían regulados por las autoridades subnacionales. Las normas relativas al comercio en los servicios - incluyendo la práctica del derecho, por ejemplo- pueden caracterizarse por esta dinámica.

90 Duncan HOLLIS ha estudiado la variedad de formas mediante las cuales los funcionarios del poder ejecutivo han tratado de evitar la imposición de esa coordinación internamente dirigida en la negociación y ratificación de los tratados. Vid. Hollis, supra nota 62, en pág. 1372-86. Reconoce la limitada eficacia de muchos de esos esfuerzos, por otra parte, así como las quizás igualmente numerosas ocasiones en las que el ejecutivo no procedió de esa manera. Vid., p.ej., id. en pág. 1375. De su explicación global, además, parece que la incidencia de las interferencias en los tratados sobre federalismo, se han incrementado con el tiempo, a pesar de esos esfuerzos. En cualquier caso, está muy difundido un marco conceptual de la coordinación externamente dirigida que impulsa una coordinación dirigida internamente.

91 Algún contraste puede establecerse entre este modelo y la necesidad del consentimiento provincial a los tratados internacionales en Canadá. Vid. infra nota 193 y texto adjunto. 
na al servicio de la coordinación dirigida externamente. También es extremadamente conflictiva. Según cierta concepción convencional existe una tensión considerable entre, de una parte, el derecho internacional y las instituciones $y$, de otra, las demandas del federalismo estadounidense ${ }^{92}$. En esta explicación bastante generalizada, el derecho internacional al menos sofoca, si no silencia, las voces nacionales, fuera de las de un conjunto reducido de actores responsable de los asuntos exteriores de los Estados Unidos ${ }^{93}$.

El paradigmático caso del Tribunal Supremo, Missouri v. Holland, "cuando el federalismo se encuentra con los asuntos exteriores", apunta este sentido del conflicto ${ }^{94}$. Tal y como se ha descrito más arriba, en Holland, el Tribunal mantuvo que el Congreso podía evitar los límites constitucionales del federalismo, en virtud del poder para firmar tratados ${ }^{95}$. A primera vista, esta sentencia ilustra las tensiones entre lo nacional y lo internacional que subyacen en la noción de conflicto en su interacción. Incluso más expresiva, sin embargo, es la inversión menos visible de fines y medios de la coordinación que se encuentra tras esa decisión. Al menos ocasionalmente, la coordinación dirigida internamente puede ser más que el medio necesario para los fines de la coordinación externamente dirigida. En algunos compromisos de nivel nacional con el derecho internacional, la coordinación dirigida internamente de lo subnacional puede constituir un fin en sí misma ${ }^{96}$.

En Holland, por lo tanto, la legislación federal en cuestión básicamente predataba a la obligación derivada del tratado cuya adopción el Tribunal apoyó autorizar. ${ }^{97}$ Como señaló Mark Manis, la negociación y adopción del tratado no fue debida a impulso internacional alguno ${ }^{98}$. Más bien nació del parecer de Elihu Root de que tal tratado era el mejor medio de defensa de la legislación norteamericana frente a su cuestionamiento constitucional ${ }^{99}$. Así, en Holland el derecho internacional se convirtió en un vehículo para alcan-

92 Vid. RESNIK, supra, nota 5, en pág. 35.

93 Los esfuerzos agresivos para que se aprobara la Enmienda Briker pueden entenderse a esta luz. Para los que apoyaban la enmienda a nivel subnacional, los acuerdos de las Naciones Unidas y los acuerdos internacionales con ellos relacionados constituían una amenaza para las normas y prácticas de los Estados y de las entidades locales relativas a la raza. Vid. Mark W. MANIS, Missouri v. Holland: Birds, Wars and Rights, en International Law Stories, 207, 220 (John E. NOYES, Laura, A. DIKINSON \& Mark W. JANIS eds. 2007).

94252 U.S. 416 (1920).

95 Id., en pág. 433.

96 En tales circunstancias, podemos pensar en la aplicación del derecho internacional como una suerte de pre-compromiso. Vid., Steven R. RATNER, Precommitment Theory and International Law: Starting a Conversation, 81 Tex. L. Rev. 2055 (2003).

97 Vid. MANIS, supra, nota 93, en págs. 209, 211.

98 Vid. id., en págs. 209-211.

99 Vid. Id.; vid. también HOLLIS, supra, nota 62, en pág. 1638 (apuntando la ironía de la previa condena de Root de la adopción de tratados "bajo fingimiento"). Es cierto que, aparentemente, se aprobó nueva legislación nada más adoptarse el tratado. Esa legislación siguió en lo esencial la pauta de la Ley Weeks-McLean, anterior al tratado, dejando claro, sin embargo, la continuidad de los esfuerzos legislativos federales en la regulación de la caza de las aves migratorias. 
zar metas de política interior. Más que la coordinación internamente dirigida, como el medio, y la coordinación externamente dirigida, como el fin, en $\mathrm{Ho}_{-}$ lland ocurrió lo contrario. El derecho internacional funcionó como el instrumento para coordinar la política interior en torno a una norma nacional determinada $-\mathrm{O}$, menos eufemísticamente, para imponer las normas federales sobre las autoridades subnacionales- ${ }^{100}$.

El resultado final puede parecer el mismo. A nivel subyacente, sin embargo, la falta de base de coordinación dirigida externamente (o, al menos, de cualquier base genuina), para la imposición del derecho internacional significa algo diferente para la relación de instituciones e intereses subnacionales, nacionales e internacionales. En tales casos, la imposición de estándares nacionales sobre las autoridades subnacionales no es una consecuencia inevitable de la persecución de otros fines; más bien, es el objetivo buscado. En el menor de los supuestos, tales casos pueden contribuir a explicar la noción fuerte de conflicto entre normas internacionales e intereses estatales y locales ${ }^{101}$.

Bien como una meta en sí misma, o motivada por el logro de la coordinación externamente dirigida, la dinámica básica de la coordinación internamente dirigida se encuentra en el núcleo de las relaciones subnacionales, nacionales e internacionales en un régimen de federalismo dual. Por medio de la Cláusula de Supremacía, los asuntos exteriores y el derecho internacional operan como un vehículo para el ejercicio del control nacional sobre la

100 Puede establecerse un paralelismo entre este modelo y la 'operacionalización' (sic) de las normas sobre derechos humanos en Europa, tal y como se describe en el enfoque "liberal republicano" de Andrew Moravcsik. Vid. Andrew MORAVCSIK, The Origins of Human Rights Regimes: Democratic Delegation in Postwar Europe, 54 Int'l Org. 217, 225-26 (2000). Allí, en esencia, los instrumentos e instituciones internacionales sobre derechos humanos, estandarizaron (es decir, coordinaron) las normas sobre derechos humanos — no sólo entre naciones-estados, sino también dentro de ellas- mediante la coordinación dirigida internamente. La analogía puede ser mínimamente útil para ilustrar la posibilidad de que el uso instrumental del derecho internacional, como medio de estimular la coordinación dirigida internamente, puede promover valores normativamente atractivos, no obstante su desviación de lo que consideraríamos la dinámica legítima de la coordinación en las relaciones subnacionales, nacionales e internacionales. La evaluación de la legitimidad correspondiente, se sugiere, puede depender de la priorización relativa que uno haga de las normas sustantivas frente a las normas de procedimiento. Vid. infra Parte V. A.

101 Quizás aunque no sorprenda, la explicación que ofrecemos de Holland —en la que el acuerdo internacional va dirigido a la coordinación interna más que externa, en el primer orden - ha sido desautorizada expresamente por las autoridades federales. Como se subraya en una circular del Departamento de Estado norteamericano: "Habría que diseñar los Tratados para promover los intereses de los Estados Unidos, asegurándose una acción de los gobiernos extranjeros de forma que se considerase ventajosa para los Estados Unidos. Los Tratados no deben utilizarse como un instrumento para producir cambios sociales internos o para tratar de eludir los procedimientos constitucionales en relación con lo que son asuntos de preocupación interna". JANIS, supra nota 93, en pág. 223 (citando la circular del Departamento de Estado N. ${ }^{\circ} 175$, de 13 de diciembre de 1955); vid. también HOLLIS, supra nota 62, en 1370 \& nn. 254-55 (señalando afirmaciones oficiales adicionales que rechazan el uso del poder de suscribir tratados en este sentido). 
política subnacional. Entonces, en un marco dualista cabe pensar en el derecho internacional -y quizás en el orden internacional en general-, como un mecanismo de sujeción subnacional.

¿Qué sucede con esta explicación, sin embargo, al "declinar" el federalismo dual tal y como se ha descrito más arriba? ${ }^{102}$ ¿Cómo debemos entender la interacción entre intereses e instituciones subnacionales, nacionales e internacionales, a medida que las voces subnacionales se van superponiendo a la vOz nacional en los asuntos exteriores? Mientras Illinois se plantea Sudán y Tejas se enfrenta con Méjico ¿cómo cambia la explicación de la coordinación en la relación entre lo subnacional, lo nacional y lo internacional?

En el caso de las sanciones contra Sudán, y la interpretación y el cumplimiento de la sentencia del TIJ en Avena, las autoridades subnacionales desempeñan el papel de participantes activos, más que de sujetos pasivos. Siendo esto así, la explicación de la coordinación dirigida internamente como medio de que las autoridades nacionales persigan el fin de la coordinación dirigida externamente parece inadecuada. Esto es solo más evidente en un caso tipo Holland en el que la coordinación dirigida internamente es un fin en sí misma. Con una creciente intervención de los Estados y las entidades locales en los asuntos exteriores y en el derecho internacional, resulta más difícil para las autoridades nacionales (federales) dirigir la coordinación interna. La noción imperante de conflicto, inherente a la interacción entre las normas internacionales y los intereses subnacionales, debe ceder también.

Mientras que el ocaso del diseño delimitador dualista en la esfera nacional disminuye necesariamente su importancia en la esfera transnacional, sin embargo no lo elimina necesariamente - $\mathrm{O}$ al menos no de inmediato-. En innumerables áreas, cabría esperar que los asuntos exteriores y el derecho internacional continúen funcionando como mecanismos para que las autoridades nacionales impongan normas de coordinación sobre las autoridades subnacionales, al servicio de la coordinación transnacional. Sin embargo, dondequiera que la absoluta exclusividad del federalismo dual ha disminuido - quizás en la imposición de sanciones a los Estados que infringen las leyes, en la interacción entre tribunales nacionales y tribunales internacionales, y en la regulación del cambio climático, descrito antes- ${ }^{103}$, la relación de las autoridades subnacionales con las normas internacionales comienza a aparecer como el diseño de la política nacional en general. En un sentido, el derecho internacional se ha convertido en otra esfera de la regulación nacional. Mientras las autoridades subnacionales no disponen de un poder de veto sobre el mismo, pueden intervenir activamente en su elaboración y evolución y pueden, incluso, gozar de un margen de actuación dentro del mismo.

102 Vid. supra Parte I.C.

103 Paul BERMAN ha expuesto una amplia enumeración de áreas en la que cabe identificar tal solapamiento. Vid. BERMAN, supra, nota 11, en págs. 1197-234. 
Según lo expuesto, el derecho internacional deja de implicar algo únicamente molesto para las autoridades subnacionales. ${ }^{104}$ Podrían objetar a algo propio de él sobre el fondo —o quizás por su uso excesivo-, pero no simplemente porque sea internacional. Normalmente, los Estados federados y las entidades locales desaprueban una legislación federal que se proponga debido a su contenido sustantivo; igualmente, cuestionan con frecuencia la federalización del derecho en uno u otro campo ${ }^{105}$ En el momento actual, en el que transitamos del federalismo dual hacia un sistema emergente de ámbitos competenciales compartidos por la federación y los Estados, cabe esperar que se vea al derecho internacional de forma similar ${ }^{106}$.

Pero, podemos todavía ir más allá. A la larga, nuestra idea de la relación entre normas internacionales e intereses subnacionales - lo que tradicionalmente hemos considerado un lugar de coacción y conflicto- puede llegar a ser totalmente diferente. Recordemos, una vez más, la intervención creciente de los Estados y las entidades locales en asuntos exteriores y en el derecho internacional, que es la causa del presente análisis. Con la ley SADA puede creerse que el Congreso ha creado una oportunidad para que los Estados y las entidades locales afronten las atrocidades de Sudán. Lo mismo ocurre con la sentencia del Tribunal en Medellin, que atribuye funcionalmente la responsabilidad de determinar la naturaleza y alcance de la ejecución de Avena a los Estados. De consecuencias similares son el Protocolo de Kyoto y la Convención para la Eliminación de todas las Formas de Discriminación contra la Mujer. En cada caso, como se ha dicho, las normas internacionales correspondientes han creado un foco para la participación subnacional ${ }^{107}$.

En esos casos, más que silenciar a las autoridades subnacionales, parece que los asuntos exteriores y el derecho internacional les han dado la oportunidad de hacerse oír. Han creado, en suma, oportunidades para que las prioridades políticas e intereses de los Estados y las entidades locales adquieran una mayor resonancia. En esta dinámica, las instituciones, las normas y el

104 Esto conlleva, desde luego, que la participación sub-nacional en el nivel internacionalversus-nacional no está de algún modo estructuralmente limitada. Así, resultan aquí pertinentes las críticas por antidemocráticas de instituciones internacionales concretas, en formas distintas de los procesos administrativos nacionales. La dinámica de participación y voz que hemos descrito, no es pertinente allí donde se ha excluido a las autoridades subnacionales de la participación en los procesos internacionales de toma de decisiones - como en el Consejo de Seguridad, el Fondo Monetario Internacional y la Organización Mundial del Comercio-. Un avance adicional en el modelo que apuntamos en este artículo podría, por lo tanto, implicar también un progreso desde una mayor receptividad nacional de la participación subnacional a una aceptación internacional de esa participación.

105 Por ejemplo, la federalización agresiva del derecho penal llevada a cabo por el Congreso en los últimos años puede criticarse desde esa posición. Vid. supra nota 30 y el texto incluido.

106 Duncan HOLLIS, en su análisis del federalismo ejecutivo, dibuja una dimensión distinta del declinar de la coordinación internamente dirigida. Vid. HOLLIS supra nota 62. Su sugerencia de incrementar los esfuerzos del poder ejecutivo para evitar compromisos internacionales que chocan con el federalismo nacional, está en la misma línea de este estudio.

107 Vid. supra, notas 55-57 y texto adjunto. 
derecho internacional, más que actuar como un control u obstáculo ofrecen un punto de encuentro para que las autoridades subnacionales promuevan sus intereses. Al tiempo que nos movemos desde el federalismo dual hacia el solapamiento competencial de las autoridades locales estatales y federales en esta materia, el derecho internacional puede llegar a ser un instrumento para expresarse en lugar de un medio de coacción ${ }^{108}$.

¿Cómo pueden los asuntos exteriores y el derecho internacional servir de portavoces? En el plano más elemental, la participación de las autoridades subnacionales en el discurso de los asuntos exteriores puede ofrecerles otra ocasión de expresarse públicamente. Así, la utilidad del derecho internacional para las autoridades subnacionales se reduciría a ofrecer un lugar en el que volver a expresar su posición. Y si pueden expresar sus intereses en otros foros, las perspectivas de éxito serán mejores. No obstante, el potencial real de los asuntos exteriores y del derecho internacional para aumentar la participación de las autoridades subnacionales va mucho más allá.

De un lado, al tomar parte en el discurso internacional, los Estados y las entidades locales pueden intervenir en un universo más amplio de actores políticos. En Estados Unidos, los políticos de los Estados estarán mejor capacitados para propugnar sus puntos de vista en derecho penal, o en otros ámbitos importantes, si actúan de acuerdo con sus colegas locales canadienses. También es probable que mediante esa intervención se incremente la calidad de las propuestas políticas y las posibilidades de éxito. Como mínimo, el establecimiento de amplios contactos, incluso más allá de las fronteras nacionales, puede resultar útil para los hombres de negocios estatales y locales.

Aún más. Es plausible que la inserción de las prioridades subnacionales bajo la rúbrica de los asuntos exteriores y el derecho internacional les confiera una relevancia de la que de otro modo carecerían. Asimismo, cuando aquellos problemas que preocupan a los Estados y a las entidades locales se planteen a nivel transnacional, recibirán, seguramente, una mayor atención nacional. El derecho internacional puede, en consecuencia, servir de centro de atención al que puedan traerse a colación las preocupaciones de los entes subnacionales ${ }^{109}$.

En esta explicación sobre la voz y la participación subnacionales, el derecho internacional empieza a significar algo distinto. Así es ahora ya, mientras nos alejamos de la noción dualista del derecho, como un mecanismo de establecimiento de líneas divisorias - como un instrumento de claridad y

108 Como se ha dicho, vid. supra nota 9, esta explicación elude buena parte de la crítica "nacionalista" del derecho internacional por antidemocrático y contrario al federalismo. La interiorización del derecho internacional por los representantes estatales del legislativo y del ejecutivo es a la vez democrática y plenamente congruente con las pretensiones del federalismo.

109 En algunos supuestos limitados, ciertas cláusulas importantes de los tratados pueden recoger explícitamente las voces de las autoridades subnacionales. Vid., p. ej., HOLLIS, supra, nota 62, en pág. 1378. 
certeza- Hasta cierto punto, podemos equivocarnos al pensar en el derecho básicamente como aquello que termina en una sala de administración de justicia. El derecho moderno y las normas comprenden algo bastante más amplio que determinados mecanismos de orden y de control. Por lo tanto, sería mejor considerar el derecho como un punto de partida para el diálogo - un marco normativo para el análisis y la acción-. Como tantas veces, puede servir como el modo de afirmar la norma y la acción. Ese derecho es "dúctil", pero puede ser no menos importante que sus análogos "rígidos". Y, aún más, puede ser no menos "derecho".

Con este espíritu, hemos estudiado en primer lugar la función del derecho y de la regulación como fuente de "ejemplos" no coactivos para favorecer la coordinación deseable ${ }^{110}$. Actos públicos significativos pueden contribuir a proporcionar alguna señal efectiva sobre el mecanismo o equilibrio último de la coordinación allí donde los grupos implicados lo demanden. Es posible imaginar que el derecho internacional desempeñe un papel en el posible fortalecimiento de las autoridades subnacionales. De esta manera, las normas internacionales pueden funcionar como fuente de centros de atención para la coordinación entre autoridades subnacionales. De hecho, esa puede ser una función especialmente importante si consideramos el papel de tal "coordinación horizontal" en la refutación de las sempiternas convicciones de caos, en el caso de que los Estados y las entidades locales interviniesen en los asuntos exteriores y en el derecho internacional $-\mathrm{y}$ la consecuente insistencia en la necesidad de contar con "una sola voz" en asuntos exteriores-.

\section{LA NUEVA COORDINACIÓN}

La introducción de voces subnacionales en la conformación de la política exterior norteamericana y en el derecho internacional tiene que tener consecuencias relativas a nuestro compromiso con el mundo. A medida que los "asuntos exteriores" y los "locales" se entrelazan"111, y los Estados federados y las entidades locales discuten cuestiones de asuntos exteriores y derecho internacional, resulta más difícil identificar una voz singular en la política exterior norteamericana ${ }^{112}$. Así lo ilustran la promulgación de la SADA y la sentencia del TS en el caso Medellín. Con la decisión del Congreso, los interlocutores potenciales de Sudán en cualquier negociación diplomática sobre sanciones, no se limitan ahora al gobierno federal. Los Estados y las entidades locales $-\mathrm{O}$, al menos, aquellos capaces de afectar a los intereses

110 Vid. AHDIEH, supra nota 7.

111 Vid. RESNIK supra nota 5, en pág. 35.

112 Vid. Margaret E. MCGUINNESS, Medellin, Norm Portals, and the Horizontal Integration of Internacional Human Rights, 82 Notre Dame L. Rev. 755 (2006) (dónde se apunta una calidad disminuida focal de los mecanismos tradicionales para la interiorización de las normas sobre derechos humanos). 
del gobierno sudanés - tienen que intervenir también. ${ }^{113}$ En Medellín es dable encontrar alguna prueba del cambio de óptica de los homónimos extranjeros de los Estados Unidos. A continuación de la sentencia del TS, aunque el Estado de Tejas consideraba que le competía a él dar el próximo paso, Méjico lo estaba dando también — con sanciones específicamente impuestas a Tejas entre sus posibles vías de acción- ${ }^{114}$.

En la Parte II vimos las formas en las que la integración de las voces subnacionales disminuye la función de coordinación dirigida internamente del derecho internacional — su función como medio de coacción-, quizás incluso, sustituyéndola por el papel de dar un voz realzada a las autoridades estatales y locales. ¿Qué podemos esperar que implique esta "polifonía" de voces para la función de coordinación dirigida externamente de los asuntos exteriores y del derecho internacional? Aunque la Parte II cuestionaba la idea de que las normas internacionales necesariamente silencien las voces subnacionales, ¿qué sucede con la exigencia de que la política en asuntos exteriores demande "una sola voz"? Aquí también ponemos en tela de juicio esa exigencia, y argüimos que descuida la posibilidad y la realidad de lo que llamaremos "coordinación horizontal".

De nuevo, es útil comenzar con la postura convencional - las nociones estándar de las implicaciones de la devolución por parte del federalismo del poder de tomar decisiones-. En la explicación tradicional, el cambio desde la autoridad federal a la autonomía estatal y local representa un movimiento

113 Alternativamente, Sudán podría continuar centrándose exclusivamente en el gobierno federal y buscar una modificación de la SADA. Sin embargo, incluso esto último significaría mayores cargas para Sudán, en comparación con una negociación sólo con las autoridades del ejecutivo federal y centrada en el alcance de las sanciones federales. Y lo que es más importante, una vez que se ha apoderado a los Estados y entidades locales para que actúen contra Estados como Sudán, puede ser difícil privarles de ese poder. Una suerte de "efecto-dotación" haría difícil recuperar el poder estatal una vez otorgado. Vid. Russell KOROBKIN, The Endowment Effect and Legal Análisis, 97 Nw. U. L. Rev. 1227, 1236 (2003).

114 Vid. Peter SPIRO, Making Texas Pay for its Sins, or Why Ernesto Medellin May Live out His Days in Prison, Opinio Iuris, 25 de marzo de 2008, http://opinioiuris.org/2008/03/25/makingtexas-pay-for-its-sins-or-why-ernesto-medellin-may-live-out-his-days-in-prison/. Como ha sostenido Peter SPIRO, ante los cambios en el derecho, la política y la economía de las relaciones internacionales - y la consiguiente aparición de entidades subnacionales como lo que denomina "semi-soberanas" - se ha incrementado el potencial de "represalia selectiva", mediante la cual los Estados extranjeros pueden dirigir su acción como respuesta a los desafueros percibidos a aquellas jurisdicciones subnacionales consideradas la fuente del agravio. Vid. Peter J. SPIRO, Foreign Relations Federalism, 70 U. Colo. L. Rev. 1223, 1261-70 (1999). La dimensión puede ser decisiva en esta dinámica, lo que convierte a los Estados en objetivos de represalia más probables que las entidades menores. En cualquier caso, allí donde las entidades extranjeras puedan dirigir su respuesta a un objetivo subnacional concreto, disminuyen necesariamente las preocupaciones por los efectos que acompañen a las tomas de decisiones subnacionales en materia de política exterior. Vid., id. en págs. 1260-62. De otra parte, resulta al menos plausible que los Estados extranjeros planifiquen la represalia no contra el culpable del agravio, sino contra aquellos otros con mayor capacidad para presionar al Estado-objetivo — como ha ocurrido con la retirada de concesiones autorizada por la Organización Mundial del Comercio a regiones políticamente sensibles dentro del Estado-objetivo (p.ej., contra la exportación de naranjas, una de las cosechas principales del Estado de Florida)_. 
hacia un tipo de autarquía, de gobierno por sí mismo. Esencialmente, un movimiento desde un régimen de jerarquía hacia la otra única posibilidad - un mercado, abierto, libre y no coordinado-. Como ha dicho Michael Greve, el federalismo "implica el «ejercicio individual, no coordinado de la soberanía estatal en una república federal»"15.

Para sus partidarios, éste es el principal atractivo del federalismo. Otorga vOz a las autoridades estatales y locales, y a la ciudadanía por la que, se cree, habla de manera efectiva. Desde una óptica más amplia, se considera que el federalismo es beneficioso porque estimula la competencia y fomenta la variedad de las opciones políticas de Estados y entidades locales. Por lo que hace a cada uno de estos beneficios, la adopción estatal de decisiones autárquicas - $\mathrm{O}$ atomizadas - es una exigencia.

En ciertas esferas del derecho y de la actividad reguladora, por el contrario, esa aceptación de la competencia autárquica y de la variedad, es considerada como un punto débil del federalismo. En algunos ámbitos de la política económica, en las normas sobre responsabilidad de los productos, en materia de protección ambiental, en el diseño y mantenimiento de las políticas redistributivas, y en otros, la competencia y la variedad se consideran el problema, no la solución. Aquí nos encontramos con la historia del federalismo como caos. O, quizás menos despreciativamente, como des-coordinación. En estas circunstancias, el federalismo es una cacofonía de voces, donde necesitamos la coherencia de una sola voz.

Es posible que ningún otro conjunto de problemas, a excepción de los asuntos exteriores y el derecho internacional, haya sido considerado que debe caer bajo esta esfera. Aquí el compromiso con la necesidad de "una vOZ" parece haberse aceptado por aclamación. De nuevo vienen a colación los ejemplos de la política sancionadora de Sudán, y de ejecución de la sentencia del TIJ en Avena. En el proceso sobre la ley de Illinois de desposesión de bienes sudaneses — como en el de la legislación sancionadora de Massachussets, contra Birmania, diez años antes ${ }^{116}$ — el problema básico era el peligro de la intervención subnacional en cuestiones de política exterior. Al anunciar el comienzo del litigio, el Consejo Nacional del Comercio Exterior (Nacional Foreign Trade Council -NFTC-) manifestó la necesidad de que el presidente «mostrara flexibilidad en el manejo de la política exterior, que combina los incentivos y los factores disuasivos destinados a modificar el comportamiento de los gobiernos extranjeros", así como la tendencia de "las sanciones impuestas por Estados individuales o por gobiernos locales [a atar] las manos del Presidente ${ }^{117}$. Cuando contestó a la decisión favorable del tribunal de distrito en Illinois, el NFTC invocó el caso Crosby v. Nacional Foreign Trade Council: "Lo fundamental de la sentencia [del Tribunal Supremo] fue que el Presidente

115 Vid. Michael S. GREVE, Compacts, Cartels, and Congressional Consent, 68 Mo. L. Rev. 285, 322 (2003).

116 Vid. Crosby v. Nat'l Foreign Trade Council, 530 U.S. 363 (2000).

117 Press Release, Nat'l Foreign Trade Council, (17 de agosto de 2006), disponible en http:// www.nftc.org/newsflash/newsflash.asp?Mode0View\&articleid=1814\&Category=All 
dirige la política exterior, no el legislativo, ni el gobernador de Massachussets. Y no necesita cincuenta Estados, ni gran cantidad de ciudades y condados, con su política de palo y zanahoria, que vaya en contra de su [balance de incentivos] ${ }^{118}$. La resistencia subsiguiente a la norma federal SADA siguió por cauces similares ${ }^{119}$. Incluso el informe del Senado sobre la legislación hacía referencia a la tensión sostenida entre la coordinación y la descoordinación en el diseño de la política exterior norteamericana. ${ }^{120}$

Los "amicus briefs"* en Medellín suscitaron preocupaciones análogas en la defensa del "memorándum" del presidente y de la instrucción a los tribunales estatales para que cumplieran la sentencia de Avena. La American Bar Association**, por ejemplo, insistió en que «en materia de relaciones internacionales, los intereses federales son supremos y excluyentes de los intereses estatales" ${ }^{121}$. Más adelante, citaba la afirmación del Tribunal Supremo en el caso Hines $v$. Davidowitz de que "la responsabilidad total y exclusiva de la dirección de los asuntos con soberanías foráneas" se encuentra en el Gobierno federal, y su insistencia en que "los intereses de las ciudades, condados y Estados, no menos que el interés del pueblo de toda la nación, requiere imperativamente que se libere de toda interferencia local al poder federal en el campo relativo a las relaciones exteriores ${ }^{122}$. En las relaciones internaciona-

118 Press Release, Nat'l Foreign Trade Council (21 de mayo de 2007), disponible en http:// www.nfct.org/newsflash/newsflash,asp?Mode=View\&articleid=1863\&Category=All.

119 La NFCT apoya totalmente los esfuerzos en pro de la paz y la estabilidad en Darfur, pero alentar a los Estados y gobiernos locales para que impongan sanciones a Sudán no es la respuesta... [Nosotros] continuamos creyendo que es en el mejor interés de los Estados Unidos y de nuestro aliados que sea el gobierno federal y no los Estados quien dirija la política exterior." Press Release. Nacional Foreign Trade Council (17 de octubre de 2007), disponible en http://www.nfct.or/newsflash/newsflash.asp?Mode=View\&articleid=1903\&Category=All (que describe la legislación como "la sub-contratación a los Estados de la política exterior").

120 Vid. S. Rep. No. 110-213, en 3 (2007) (Sudan Accountability and Divestment Act, de 2007) ("La Comisión reconoce que esta legislación implica que se sopesan dos intereses. El primero, la autoridad singular del Gobierno Federal para dirigir la política exterior. La segunda, la competencia de los gobiernos estatales y locales para invertir o sacar sus fondos como crean conveniente. La Comisión cree que ha establecido un balance apropiado al señalar como objetivo la actividad del Estado, de manera tal que permita medidas expropiatorias basadas en los riesgos para la obtención de beneficios, el bienestar económico y la imagen, derivados de la asociación con inversiones en un país sometido a sanciones internacionales").

* N. del T.: Un "Amicus Brief " o "Amicus Curiae Brief" es un breve informe que remite un tercero - que no es parte en el proceso- a un Tribunal para ayudarle con objeto de que adopte la resolución adecuada.

** N. del T.: La American Bar Association es una suerte de Colegio Nacional Norteamericano de Abogados que pretende mejorar la administración de justicia en general.

121 Informe de la American Bar Association como "Amicus Curiae" en Apoyo del demandante, en pág. 11, Medelín v. Tejas, 128 S.CT. 1346 (2008).

122312 U.S. 52, 63 (1941). El informe citaba además el caso Board of Trustees of University of Illinois v. United States, 289 U.S. 48, 59 (1933) ("En las relaciones internacionales y en lo que respecta al intercambio y el comercio exterior, el pueblo de los Estados Unidos actúa a través de un solo gobierno con el poder nacional unificado y adecuado"), y The Federalist N. ${ }^{\circ} 80$, en el que Alexander HAMILTON insistía en que "la paz del todo no debe dejarse a disposición de una parten. Vid. The Federalist, N. ${ }^{\circ} 80$. 
les, sobre todas las áreas, es decisivo «asegurar que todo el país habla con una sola voz" ${ }^{123}$.

El "amicus brief" presentado por el Decano Harold Hongju Koh y la Clínica de Derechos Humanos Lowenstein en nombre de antiguos diplomáticos norteamericanos era todavía más explícito. Permitir que el Estado de Tejas actuara por su cuenta, decía el informe, "provocaría precisamente el tipo de error que llevó a la creación del poder de hacer tratados en primer lugar» ${ }^{124}$. La frustración de los Padres Fundadores con la adjudicación disfuncional del poder federal-estatal bajo los Artículos de la Confederación ${ }^{125}$ nos enseñó que permitir a los Estados debilitar las obligaciones contraídas por la nación mediante un tratado, podría dificultar notablemente el despliegue nacional de los asuntos exteriores" ${ }^{126}$. "Como claramente establecen el texto y la estructura de las disposiciones constitucionales aplicables, en aquello que concierna a la política exterior de nuestra nación, la Constitución no reconoce soberanía dual alguna" ${ }^{127}$. Y lo que es más digno de recuerdo, el "amicus brief" cita los términos del caso United States $v$. Belmont: "En lo relativo a todas las negociaciones y convenios internacionales, y en lo que respecta a nuestras relaciones exteriores en general,... el Estado de New York no existe.. ${ }^{128}$

Así pues, para las sanciones a Sudán y para Medellín, la resistencia a que las autoridades subnacionales participasen en los asuntos exteriores se fundamentaba en una "teoría del caos" que no merecía totalmente tal nombre. El compromiso con Estados extranjeros, según dicta la lógica, no puede realizarse a distintos niveles ${ }^{129}$. Como un ejercicio de coordinación externamente dirigida, requiere de la coordinación internamente dirigida. Ningún otro camino es viable.

Pero la creciente participación de los poderes subnacionales en los asuntos exteriores y en la elaboración del derecho internacional ¿impone de hecho una pérdida de coordinación? ¿Existe alguna alternativa a la autarquía implícita —incluso caos - que supone la explicación estándar del federalismo?

Contrariamente al común saber y entender, esa alternativa existe. Las nuevas voces de los poderes subnacionales no necesitan imponer pérdida alguna de coordinación. Más bien, lo que cambia es simplemente la naturaleza de dicha coordinación. En lugar del modelo tradicional, centralizado, la

123 Informe de la American Bar Association, supra nota 121, en pág. 13.

124 Informe de los Antiguos Diplomáticos Norteamericanos, como "Amici Curiae" en apoyo del demandante en pág. 17, Medellín, 128 S. Ct. 1346 (N. ${ }^{\circ}$ 06-984), 2007 WL 1886206.

125 Vid. id., en págs. 17-18.

126 Vid. id., en pág. 17.

127 Id. en pág. 20 (citando The Federalist N. 42 (James MADISON) ("Si tenemos que ser una nación bajo cualquier consideración, tenemos que serlo ante las otras naciones").

128 Id. en págs. 20-21 (citando United States v. Belmont, 301 U.S. 324, 331 (1937)).

129 Jide NZELIBE ha puesto en cuestión el motivo convencional esgrimido de la autoridad del Presidente en materia de asuntos exteriores porque es relativamente menos provinciana que la del Congreso. Vid. Jide NZELIBE, The Fable of the Nationalis President and the Parochial Congreso, 53 Ucla L. Rev. 1217 (2006). La verdad es que, dados la estructura de las elecciones presidenciales y el sistema colectivo de adopción de decisiones del Congreso, lo opuesto puede ser cierto. 
dinámica de la coordinación que opera en la intervención de las autoridades subnacionales en los asuntos exteriores y en el derecho internacional es de naturaleza horizontal. La coordinación puede lograrse y, quizás, puede esperarse; pero no puede simplemente imponerse ${ }^{130}$.

Esto puede entenderse tanto desde la perspectiva conceptual como desde la empírica. Por lo que hace a la primera, el estudio de los procesos de establecimiento de estándares y de los trabajos teóricos de los denominados "juegos de coordinación" puede servir para ilustrar la dinámica cambiante de la coordinación, a medida que la creciente intervención subnacional en los asuntos exteriores nos desplaza desde la exclusividad del trazado lineal del federalismo dual hacia la concurrencia, el solapamiento y la complejidad en nuestra economía política nacional. El entendimiento de esos trabajos disminuye enseguida nuestra preocupación tradicional por la posibilidad de descoordinación, al tiempo que apunta a distintos peligros que pueden merecer nuestra atención.

En la abundante bibliografía sobre el establecimiento técnico de estándares se destacan generalmente tres mecanismos de coordinación ${ }^{131}$. Las dos primeras posibilidades se hacen eco de la bibliografía sobre federalismo. El establecimiento de estándares de jure implica la imposición centralizada de un estándar común. En la esfera técnica, el proceso de establecimiento de estándares P2P, recientemente iniciado en la Unión Europea para las transmisiones vía internet sirve de ejemplo de tal establecimiento de estándar de jure $^{132}$. El diseño de políticas coordinadas a nivel nacional y su imposición sobre las autoridades subnacionales, desde luego, es el establecimiento de estándar de jure del federalismo.

En el otro extremo, los estándares de facto son aquellos que se desarrollan gradualmente mediante la adopción atomizada de decisiones por parte de actores individuales. Tales estándares surgen sobre todo del mercado. Entre otros estándares de facto en el ámbito técnico, los más conocidos son el sistema operativo Windows de Microsoft, y el formato PDF ampliamente utilizado para la entrega de documentos ${ }^{133}$. En el federalismo ésta es la dinámica evocada por Michael Greve cuando habla del federalismo como «el ejercicio individual, no coordinado, de soberanía estatal en una república federal ${ }^{134}$.

130 Importa reiterar que lo que nos interesa estudiar son los modelos de coordinación nacional. Obviamente, más allá de las fronteras nacionales también actúan dinámicas análogas de coordinación. La naturaleza de la coordinación en este contexto necesita asimismo de atención, pero de momento no es objeto del presente análisis.

131 Vid. Margaret Jane RADIN, Online Standardization and the Integration of Text and Machina, 70 Fordham L. Rev. 1125, 1135-37 (2002); vid. también Robert B. AHDIEH, The Role of Groups in Norm Transformation: A Dramatic Sketch, In Three Parts, 6 Chi. J. Int'l L., 231 244-45 (2005).

132 Vid. New Tecnologies, Comm. Daily, 20 de febrero de 2008.

133 En el año 2005, el sistema PDF fue adoptado por la Organización Internacional de Estándares (ISO) y se convirtió por ello en lo que algunos denominarían un estándar de jure. Vid. Betsy Fanning, PDF Standards, Aiim E-Doc Mag., 1 de julio de 2007, en pág. 58.

134 Vid. GREVE, supra nota 115, en pág. 322. 
En contraste con la bibliografía sobre el federalismo, la que versa sobre el establecimiento de estándares reconoce además una tercera posibilidad. Denominada de varias formas, como establecimiento de estándares "de grupo" o "de comisión", la coordinación no es aquí ni el resultado de una orden centralizada, ni una dinámica puramente de mercado en la que la toma atomizada de decisiones puede producir o no resultados coordinados. En este caso estamos más bien ante una coordinación que nace de la coordinación real. En el establecimiento de estándares de grupo, las redes de los actores importantes intervienen en varios modelos de discurso, colectivos o individualizados (uno después de otro $)^{135}$. De esta manera, la coordinación nace de la negociación.

La bibliografía relativa a "redes" ofrece aún más matices sobre esta tercera posibilidad. Walter Powell acertadamente escribió que las redes eran una forma de organización que no constituía "ni un mercado ni una jerarquía" "136. Estas redes no muestran la internacionalización de funciones económicas y la dinámica jerárquica resultante que son características de una empresa. ${ }^{137}$ Por otra parte, implican algo más que la contratación a distancia —el contrapunto convencional a la empresa- ${ }^{138}$. Las transacciones se producen "a través de redes de individuos involucrados en actuaciones recíprocas, preferentes y de apoyo mutuo" "139. En una dinámica de red como ésta "las unidades individuales no existen por sí mismas, sino en relación con otras unidades" ${ }^{140}$.

La dinámica del establecimiento de estándares de grupo, de la organización de redes y de otras formas de lo que yo he denominado "coordinación horizontal" ofrece puntos de vista determinantes sobre las implicaciones de la creciente participación de las autoridades subnacionales en materia de asuntos exteriores y derecho internacional ${ }^{141}$. En esencia, el cambio de una única autoridad decisora a nivel nacional, conforme al federalismo dual, a una pluralidad de voces, puede entenderse como un proceso progresivo a través de cada una de las posibilidades de establecimiento de estándares antes señala-

135 En diversas áreas de la alta tecnología el establecimiento de estándares de grupo es muy común, y el ejemplo más destacado es quizás el Internet Engineering Task Force (IRTF), http:// www.ietf.org (visitada por última vez el 26 de septiembre de 2008); vid. también Berman, supra nota 11, en 1222-23; Philip J. WEISER, The Internet Innovation, and Intellectual Property Policy, 103 Colum. L. Rev., 534, 542 (2003).

136 Vid. Walter W. POWELL, Neither Market Nor Hierarchy: Network Forms of Organization, 12 Res. Org. Behav. 295 (1990).

137 Vid. Oliver E. WILLIAMSON, markets and hierarchies: analysis and antitrust implications (1975).

138 Vid. $i d$.

139 Vid. POWELL, supra nota 136, en pág. 303.

$140 \mathrm{Vid}$. $\mathrm{id}$. El estudio de las redes transgubernamentales — de forma clara en el trabajo de Anne-Marie SLAUGHTER - señala esta conexión incluso de forma más explícita. Vid., p. ej., Anne-Marie SLAUGHTER, a new world order (2004); Anne-Marie SLAUGHTER, Global Government Networks, Global Information Agencies, and Disaggregated Democracy, 24 Mich. J. Int'l L. 1041 (2003); vid. también Kal RAUSTIALA, The Architecture of International Cooperation: Transgovernmental Networks and the Future of International Law, 43 VA. J. Int'l L. 1 (2002).

141 La bibliografía sobre los juegos de coordinación se refiere asimismo a esta dinámica de interacción. Vid. infra notas 229-237 y el texto que las acompaña. 
das. Como ya hemos indicado, la dinámica de la coordinación de jure es patente en el desarrollo de políticas a nivel nacional. La introducción de voces subnacionales, en cambio, nos lleva a la segunda posibilidad —el establecimiento de estándares de facto-. Aquí, cualquier grado de coordinación externamente dirigida en asuntos exteriores y derecho internacional depende de las decisiones atomizadas de un universo creciente de autoridades subnacionales. Aun siendo así, la coordinación es posible. De hecho, en muchas áreas técnicas la estandarización se ha logrado justamente por esta vía ${ }^{142}$. Sin embargo, cualquier coordinación que surja no supone una coordinación real —un compromiso positivo- entre los Estados y entes locales implicados.

Este no es el caso si nos dirigimos a la tercera posibilidad. Las dinámicas de establecimiento de estándares de grupo, como ya se ha sugerido, implican la búsqueda activa de la coordinación. En esta dinámica, las autoridades subnacionales confían en diversos grupos, estructuras y procesos — redes de algún tipo- para lograr la coordinación necesaria en el proceso de toma de decisiones que, de otra forma, sería atomizado. La coordinación externamente dirigida puede así asegurarse, aunque sencillamente a través de formas distintas. Estos modelos pueden representar una aproximación atractiva en áreas en las que la coordinación es una necesidad imperiosa, como en el área de los asuntos exteriores y el derecho internacional.

Se puede entender, además, que esta coordinación horizontal entre autoridades subnacionales no implica diferencias cualitativas, sino simplemente de grado. Incluso con la ausencia de participación subnacional, la coordinación internacional se consigue hoy en día sin la ayuda de un mecanismo centralizado de coordinación ${ }^{143}$. La elaboración del derecho inter-

142 Algunos aspectos de la regulación internacional bancaria puede considerarse que se han desarrollado de esta forma. Vid. David ZARING, Informal Procedure, Hard and Soft, in International Administration, 5 Chi. J. Int'l L. 547, 573-80 (2005); vid. también Janet KOVEN LEVIT, $A$ Bottom-Up Approach to International Lawmaking: The Tale of Three Trade Finance Instruments, 30 Yale J. Int'l L. 125 (2005).

143 Esto muestra claramente una diferencia crucial entre las dinámicas de coordinación nacionales y las transnacionales. Con notables excepciones, las últimas se caracterizan por la ausencia de lo que podríamos llamar un "decisor". En el trabajo al que yo me refiero en mi análisis de la coordinación multinivel —que denominaré infra como "gobernanza intersistémica"— Robert COVER y Alexander ALEINIKOFF reconocen un modelo de "federalismo dialéctico" a partir del solapamiento competencial de los tribunales penales estatales y los tribunales federales inferiores en el ejercicio de la labor judicial. Vid. Robert M. COVER \& T. Alexander ALEINIKOFF, Dialectical Federalism: Habeas Corpus and the Court, 86 Yale L.J. 1035 (1977). En la explicación de COVER y ALEINIKOFF, el Tribunal Warren inicia el proceso, señalando los principios de apertura y cierre relativos a los derechos constitucionales de los abogados defensores. Los tribunales penales estatales son llamados a aplicar estos principios en primera instancia, desde la perspectiva de que su máxima responsabilidad es el control del crimen. En fase de revisión, en cambio, los tribunales federales inferiores aplican los mismos principios, pero desde su perspectiva diferente, la del desarrollo de un determinada política constitucional. Dado que ninguno puede determinar el resultado final - los tribunales estatales pueden rechazar interpretaciones propuestas por los tribunales federales, mientras que éstos pueden garantizar el habeas a los condenados en tribunales estatales - los tribunales federales y estatales están obligados a mantener una relación dialéctica de la que surgen nuevos paradigmas del procedimiento constitucio- 
nacional ya es un tipo de establecimiento de estándares de grupo, más que de estándares de jure. La intervención subnacional en materia de asuntos exteriores simplemente incrementa el tamaño del grupo correspondiente. Sin embargo, puede incrementar la complejidad de la coordinación transnacional, de modo que la participación subnacional en esta materia sea difícilmente compatible con ella. En cierto sentido, no tiene mayor significado para la naturaleza esencial de esa coordinación - otro que no sea el beneficio que obtiene la autoridad nacional, que no seguiría ocupando el lugar principal por mucho tiempo- ${ }^{144}$.

Pasando de la construcción teórica de la coordinación horizontal a las manifestaciones empíricas de la misma, en los últimos años hemos podido observar la práctica creciente de un tipo de establecimiento de estándares de grupo entre autoridades subnacionales. No ha faltado coordinación, pero ésta ha surgido de un conjunto de asociaciones, más o menos formalizadas, de políticos de Estados y entes locales. En un trabajo reciente, Judith Resnik ha ofrecido ejemplos importantes de lo que ella denomina "federalismo horizontal" e "institucionalismo translocal ${ }^{145}$. En estos casos, los entes subnacionales están activamente coordinados con otros para abordar cuestiones políticas de interés común.

Entre los ejemplos de esas redes se incluyen: la Liga Nacional de Ciudades (National League of Cities), la Asociación Nacional de Gobernadores (National Governors' Association), la Asociación Estadounidense de Alcaldes (U.S. Conference of Mayors), la Asociación Nacional de Fiscales Generales (National Association of Attorneys General), la Asociación Nacional de Legisladores Estatales (National Conference of State Legislatures), y la Asociación Nacional de Jefes de Justicia de los Tribunales Estatales (National Conference of Chief Justices of State Courts). Otras asociaciones similares operan más allá de las fronteras nacionales, como "Ciudades Unidas y Gobiernos Locales", una asociación transnacional de entes locales, y la "Asociación Internacional de Acción en materia de Carbón", en la que diez estados norteamericanos y dos provincias canadienses se han unido a otros gobiernos nacionales con objeto de promover un sistema de "cap-and-trade" para

nal penal. Después de un tiempo de esta novedad jurídica, sin embargo, el Tribunal Supremo finalmente intervendrá para poner fin a este diálogo entre tribunales. Vid. id. en pág. 1046-68.

En el contexto transnacional con el que he comparado este último modelo, a diferencia de éste, no existe ningún Tribunal Supremo capacitado para poner fin al proceso. Así, en el caso del Tratado de Libre Comercio (NAFTA), en materia de conflictos relativos a inversiones extranjeras, no se ha previsto la existencia de ninguna autoridad - incluyendo en aspectos importantes a los propios estados implicados- que esté capacitada para resolver definitivamente el conflicto. Vid. Robert B. AHDIEH, Between Dialogue and Decree: International Review of National Courts, 79 N.Y.U. L. Rev. 2029, 2063 n.136 (2004). En el ámbito transnacional, como tal, la relación dialéctica entre diferentes jurisdicciones no es simplemente el medio de llegar a un fin claro y discreto, sino más bien el fin mismo.

144 Considérese, por analogía, la disolución de la Unión Soviética en las repúblicas que se han constituido a partir de ella. Mientras éstas han incrementado el número de participantes en las relaciones internacionales, ello no ha alterado de forma sustantiva las dinámicas subyacentes a esas relaciones internacionales

145 Vid. RESNIK, supra nota 5, en pág. 34, 44. 
las emisiones de carbón ${ }^{146}$. También pueden identificarse otras asociaciones menos organizadas de políticos subnacionales, sobre todo en ámbitos de regulación más técnicos ${ }^{147}$.

Las cuestiones políticas que se abordan en el ámbito de estas redes horizontales locales son muy variadas. Además del cambio climático, entre las últimas materias en las que se ha puesto más énfasis se incluyen la seguridad alimentaria, los derechos de la mujer, y los derechos humanos en general ${ }^{148}$. La crisis de Darfur, por ejemplo, ha sido objeto de reciente discusión en la Asociación Estadounidense de Alcaldes ${ }^{149}$. Un número cada vez mayor de Estados federados está estudiando tomar medidas económicas contra Sudán, en muchos casos consultando con Estados que ya han adoptado medidas de ese tipo ${ }^{150}$. En estas y otras materias las autoridades estatales y locales se han puesto de acuerdo en políticas comunes y han coordinado sus esfuerzos para promover esas decisiones políticas entre otros Estados federados y entes locales, a nivel nacional e, incluso, transnacional.

Estos esfuerzos se pueden considerar realmente como ejemplos de establecimiento de estándares de grupo - mecanismos conforme a los cuales se pueden articular y establecer políticas en las que existe un acuerdo o alineamiento suficiente-. Más que ante un establecimiento de estándares de jure en la toma de decisiones a nivel nacional, o ante el caos en la definición de políticas que se espera por la atribución de poderes de decisión a las autoridades subnacionales, nos encontramos ante algo diferente. El alineamiento político se logra sin recurrir a una coordinación centralizada. La política cada vez más coordinada sobre Sudán surge, no de la autoridad única del Gobierno federal para dictar esa política, sino de una dinámica descentralizada, aún preactiva, de coordinación horizontal.

Incluso cuando emergen nuevas voces en materia de asuntos exteriores y derecho internacional, y hay un desplazamiento del federalismo dual hacia una competencia compartida y solapada, la expectativa arraigada de caos y desorden político puede resultar exagerada. No hay necesariamente una pérdida de coordinación externamente dirigida, a pesar del declive del federalismo dual y de modelos similares de coordinación internamente dirigida. Existen otros mecanismos capaces de lograr esa coordinación - y quizás incluso

146 Vid. supra nota 4 y el texto que la acompaña. Otros ejemplos incluyen La Unión Internacional de Autoridades Locales, y el Consejo Internacional para el Desarrollo de Iniciativas Medioambientales Locales (ICLEI) que se desarrolló a partir de ella en 1990, así como una coalición importante de setenta de las ciudades más grandes del mundo (dirigida a la reducción de emisiones de gases con efecto invernadero). Vid. RESNIK, CIVIN \& FRUEH, supra nota 4, en pág. 719.

147 Vid. Peter M. HAAS, Introduction: Epistemic Communities and International Policy Coordination, 46 Int'l Org. 1 (1992).

148 Siendo así, los impulsos para la coordinación a través de estas (y otras) áreas varía considerablemente, desde cuestiones externas, hasta razones relativas a la política interna de las autoridades implicadas. Sin embargo, la dinámica última de la coordinación horizontal es análoga.

149 Vid. supra nota 38 y el texto que la acompaña.

150 Vid. RESNIK, supra nota 75, en pág. 1131, nota 138) (señalando los esfuerzos de coordinación en el desarrollo de una política sancionadora subnacional). 
se puede esperar que lo consigan - allí donde haya políticas que tenga la relevancia para ello.

Una coordinación horizontal de este tipo, entre autoridades subnacionales en materia de asuntos exteriores, puede adoptar diferentes formas. Se puede observar muy fácilmente en el caso de posibles redes dirigidas a la imposición de sanciones. En un extremo, podemos imaginar un pequeño grupo de Estados federados y/o entes locales comprometidos con la imposición de sanciones a un objetivo concreto, como, por ejemplo, Sudán, que informalmente contactan entre sí para coordinar sus políticas sancionadoras y así maximizar su eficacia. Al otro lado del espectro nos encontraríamos el escenario aparentemente menos probable de una red bien estructurada de autoridades subnacionales, dirigida por el principio mayoritario, de modo que la decisión política de la mayoría sea vinculante para todos. Entre estos dos extremos se pueden situar diferentes grados de organización, desde redes subnacionales que actuasen dentro de organizaciones preexistentes, como la Liga Nacional de Ciudades o la Asociación Nacional de Gobernadores, hasta redes libres ${ }^{151}$, y diferentes grados de permanencia, desde las redes cuyo objetivo es Sudán u otro objetivo concreto sancionable, hasta un "comité sancionador" estable, con vocación de permanencia, compuesto por estados y/o entes locales interesados ${ }^{152}$. Además, también se pueden observar diferentes niveles de coerción, estando en un extremo el modelo mayoritario señalado anteriormente, y en el otro la completa libertad para desligarse de la voluntad del grupo — quizás dependiendo del grado de diversidad que exista entre las preferencias de los Estados y entes locales participantes_ ${ }^{153}$.

De manera significativa, incluso el último supuesto señalado resultaría coordinador de forma natural, a pesar de su incapacidad para asegurar un acuerdo completo entre Estados y entes locales en la política sancionadora a adoptar. Para empezar, incluso con un régimen de coordinación exclusivamente voluntario, una mayor capacidad de los participantes para comprometerse en las actuaciones que correspondan puede producir mayor congruencia que la que de otra forma podría lograrse. Más claramente, incluso una coordinación totalmente voluntaria puede fomentar una mentalidad diferente entre sus participantes. Como Alexander Aleinikoff ha expresado:

"En estos espacios (interactivos), los Estados normalmente buscan ser "buenos ciudadanos". Es decir, reconocen (u otros les presionan para que

151 Cfr. Amitai AVIRAM, A Paradox of Spontaneous Formation: The Evolution of Private Legal Systems, 22 Yale L. \& Pol'y Rev. 1, 19-24 (2004) (que explora el desarrollo de nuevas redes partiendo de otras ya creadas ("piggy-backing").

152 Uno podría razonablemente esperar con el paso del tiempo un movimiento gradual a lo largo de este espectro de institucionalización.

153 Por ejemplo, un territorio subnacional puede tener una relativamente amplia población de inmigrantes sudaneses y, por ello, importantes contactos económicos con Sudán. Otro puede ser el lugar en el que tenga su centro principal una empresa petrolífera que trabaja en ese país. En ambos casos, las autoridades podrían mostrar una mayor resistencia a la imposición de sanciones desde cualquier nivel de gobierno. 
reconozcan) la responsabilidad con el sistema en su conjunto. La idea no es que todos los actores estén de acuerdo o conformes con concretas normas transnacionales, sino, más bien, que probablemente actúen de un modo que respalde el proceso de diálogo y negociación en su conjunto... en ambos casos por el trabajo que la falta de interconexión provoca y por lo que los Estados entienden que son sus propios intereses ${ }^{* 154}$.

Por lo menos, cabe esperar que un compromiso de ese tipo reduzca los conflictos más enconados en la decisión política que haya que tomar, aunque no sea capaz de producir una política única y unificada. Además, puede resultar un nivel suficiente de coordinación, dependiendo del objetivo del régimen de sanciones concreto. Incluso la decisión sólo de un par de actores - dejando al margen a un gran grupo de Estados o entes locales- de imponer sanciones puede producir su efecto en el objetivo sancionado, a pesar de que otros Estados y entes locales se nieguen a seguir ese ejemplo. Naturalmente, la extensión del aislamiento al que se sancione a un Estado será necesariamente menor en este último caso. En muchos regímenes sancionadores, sin embargo, el impacto negativo en el Estado sancionado puede lograrse incluso sin un aislamiento completo.

En la Parte II vimos que la noción convencional del derecho internacional como mecanismo por el que las voces subnacionales son silenciadas es cada vez menos sostenible. A medida que se produce una mayor participación subnacional en la creación y aplicación del derecho internacional, las ideas tradicionales sobre el derecho internacional como mecanismo de coordinación internamente dirigida, que opera al servicio de la coordinación externamente dirigida, requieren ser reconsideradas. En esta Parte III, en cambio, se ha puesto de manifiesto que este declive de la coordinación internamente dirigida necesariamente, no socava la posibilidad de lograr la coordinación externamente dirigida. La noción tradicional según la cual es necesaria una única voz nacional en materia de asuntos exteriores también resulta falsa. La coordinación en esta materia puede lograrse a través del compromiso de una pluralidad de voces estatales y locales. A diferencia del modelo convencional, la coordinación vertical, la nueva coordinación en asuntos exteriores es simplemente horizontal por naturaleza.

\section{LA GOBERNANZA INTERSISTÉMICA DE LAS RELACIONES SUBNACIONALES, NACIONALES E INTERNACIONALES}

A partir de lo anterior, parecen cada vez menos sostenibles las ideas dominantes sobre quién debe tener voz en la relación entre instituciones e intereses subnacionales, nacionales e internacionales. A medida que los Estados y entes locales participan cada vez más en la creación, evolución e imple-

154 T. Alexander ALEINIKOFF, Transnational Spaces: Norms and Legitimacy, 33 Yale J. Int'l L. 479, 485 (2008). 
mentación del derecho internacional, es menos posible concebir este derecho como un mecanismo por el que las autoridades nacionales imponen la coordinación entre las autoridades subnacionales. Dado el potencial de la coordinación horizontal, además, una política exterior coherente no necesita que sólo "una voz" — la de la autoridad nacional - sea escuchada.

Entonces ¿dónde nos coloca esto? A la vista de lo anterior ¿cómo cabe esperar que sean las relaciones entre lo subnacional, lo nacional y lo internacional a partir de ahora? Para realizar un análisis equilibrado, quisiera explorar la posibilidad de que modelos de lo que yo he denominado "gobernanza intersistémica" puedan ofrecer un marco de referencia útil para dar respuesta a estas cuestiones. Tal y como la explicación anterior ha puesto de manifiesto, la creciente integración de voces subnacionales no supone el desplazamiento de la voz nacional. Se trata de una adición más que de una sustitución - lo que Robert Schapiro ha denominado "polifonía"— ${ }^{155}$. Un régimen de gobernanza intersistémica en las relaciones subnacionales, nacionales e internacionales nos coloca en algún lugar entre la jerarquía tradicional en la definición de políticas nacionales en materia de asuntos exteriores y la alternativa amenazadora del mercado, con la descoordinación y el caos que se le supone. ¿Qué más podemos decir sobre lo que puede surgir en lugar del federalismo dual y la "VOz única" de la autoridad nacional en asuntos exteriores y derecho internacional?

Durante muchos años, el estudio académico del federalismo no se ha ocupado de integrar los cambios generados por el declive del federalismo dual en los Estados Unidos. Sin embargo, una nueva ola de estudiosos ha comenzado a cubrir esta laguna. Desde un conjunto de diferentes áreas materiales, y con distintos métodos descriptivos, normativos, microanalíticos e interdisciplinares, estudiosos entre los que se incluyen Alex Aleinikoff, Paul Berman, Bill Buzbee, Erwin Chemerinsky, Kirsten Engel, Vicki Jackson, Renee Jones, Jason Mazzone, Judith Resnik, Mark Roe, Mark Rosen, Robert Schapiro, Bob Thompson y Phil Weiser han empezado a explorar las dinámicas de "federalismo polifónico", "pluralismo", "federalismo horizontal", "convergencia, resistencia y compromiso", "federalismo interactivo", "gobernanza colaborativa", "federalismo dinámico" y otras similares ${ }^{156}$. Dejando a un lado

155 Vid. Robert A. SCHAPIRO, Polyphonic Federalism: State Constitutions in the Federal Courts, 87 CAL. L. REV. 1409 (1999).

156 Vid., p. ej., T. Alexander ALEINIKOFF, International Law, Sovereignty, and American Constitutionalism: Reflections on the Customary International Law Debate, 98 Am. J. Int'l L. 91 (2004); BERMAN, supra nota 11; Kirsten H. ENGEL, Harnessing the Benefits of Dynamic Federalism in Environmental Law, 56 Emory L.J. 159 (2006); Vicki C. Jackson, Constitutional Comparisons: Convergence, Resistance, Engagement, 119 Harv. L. Rev. 109 (2005); Renee M. JONES, Dynamic Federalism: Competition, Cooperation and Securities Enforcement, 11 Conn. Ins. L.J. 107 (2004); RESNIK, supra nota 5; SCHAPIRO, supra nota 155; Robert B. THOMPSON, Collaborative Corporate Governance: Listing Standards, State Law, and Federal Regulation, 38 Wake Forest L. Rev. 961 (2003). Podría decirse que Paul BERMAN ha sido el que ha ido más lejos explorando los matices de estos modelos — bajo la rúbrica del "pluralismo legal»-. Vid., p. ej., BERMAN, supra nota 11. 
importantes diferencias, el elemento común a todo este conjunto de trabajos es el abandono del federalismo dual delimitador de diferentes espacios competenciales y la identificación —e incluso acogida - de competencias superpuestas o solapadas.

Mi propio trabajo lleva la rúbrica de "gobernanza intersistémica" para describir modelos de gobernanza nacional y transnacional ${ }^{157}$ que están surgiendo a medida que abandonamos nuestra obsesión por que exista una competencia exclusiva, tal y como ofrece el federalismo dual ${ }^{158}$. De forma contraria al proyecto tradicional del derecho - de analizar y atribuir competencias y, de este modo, categorizar y delimitar-, yo creo que sería bueno admitir la pluralidad de actores en el ejercicio de una competencia y la interdependencia resultante entre autoridades formalmente independientes. Más que una situación que debe corregirse, esa "superposición competencial" —y la complejidad que implica- son algo que debemos aceptar e incluso que debemos tratar de integrar en nuestros regímenes jurídicos ${ }^{159}$.

A continuación, comenzaré por señalar algunos de los elementos centrales de un régimen de gobernanza intersistémica. Aunque no sea una descripción completa, sí ofrecerá una imagen suficiente de los modelos de gobernanza que tengo en mente. Posteriormente analizaré la contribución que aún realizan las autoridades nacionales en un régimen de gobernanza intersistémica. Y, finalmente, expondré varios casos ejemplificativos, a partir de los cuales podemos obtener un cuadro completo de lo que la gobernanza intersistémica podría suponer para la relación entre instituciones e intereses subnacionales, nacionales e internacionales, tanto en asuntos exteriores y derecho internacional, como en otras materias.

\section{IV.1. LOS ELEMENTOS DE LA GOBERNANZA INTERSISTÉMICA}

Algunos de los rasgos esenciales de la gobernanza intersistémica nos ayudan a definir su naturaleza: superposición competencial, centralidad de la coordinación, interdependencia de instituciones formalmente independientes y el papel importante que desarrolla la persuasión en la determinación del efecto jurídico final ${ }^{160}$. Estos elementos pueden no estar siempre presentes en

157 Vid., p. ej., ROBERT B. AHDIEH, From Federalism to Intersystemic Governance: The Changing Nature of Modern Jurisdiction, 57 Emory L.J. 1 (2007) [en adelante, AHDIEH, Modern Jurisdiction]; ROBERT B. AHDIEH, The Dialectical Regulation of Rule 14a-8: Intersystemic Governance in Corporate Law, 2 J. Bus. \& Tech. L. 165 (2007) [en adelante, AHDIEH, Rule 14a-8]; AHDIEH, supra nota 77.

158 Yo ya he cumplido mi propia cuota de experimentación al elegir denominaciones rimbombantes, algunas relativas a "distribución instersistémica", "regulación intersistémica", "regulación dialéctica" y "gobernanza mixta".

159 Vid. AHDIEH, supra nota 143, en pág. 2063-64; vid. también AHDIEH, supra nota 77, en pág. 879-96.

160 Vid. AHDIEH, Modern Jurisdiction, supra nota 157, en pág. 5; vid. también AHDIEH, supra nota 143, en pág. 2087-101. Respecto a aquellas situaciones en las que están presentes 
las interrelaciones que yo considero que forman parte del conjunto de la gobernanza intersistémica ${ }^{161}$. Pero es relativamente probable que aparez$\operatorname{can}^{162}$.

El rasgo inicial de la gobernanza intersistémica es, naturalmente, un determinado grado de superposición o solapamiento competencial ${ }^{163}$. Las autoridades estatales y locales comparten cada vez más ámbitos competenciales con el Gobierno federal en la regulación de individuos, instituciones e, incluso, conductas particulares. Por ejemplo, en derecho de sociedades y mercado de valores, he descrito las distintas formas mediante las cuales la Comisión del Mercado de Valores (Securities and Exchange Comisión-SEC) se vio forzada a compartir sus competencias sobre Wall Street con el entonces Fiscal General de Nueva York, Eliot Spitzer. A la inversa, los Estados —especial-

éstas y similares características de la gobernanza intersistémica se produce mayor debate sobre el creciente grado de complejidad, en comparación con las construcciones "dualistas" de jurisdicción exclusiva. Cuando miramos más allá de esa complejidad, sin embargo, creo que podemos adivinar modelos como los apuntados en esta sección. Vid. AHDIEH, Modern Jurisdiction, supra nota 157 , en pág. 6-7.

161 Junto a las cuatro características esenciales descritas, también debemos señalar un par de prerrequisitos necesarios para el surgimiento de un sistema de gobernanza intersistémica. El primero es cierta coincidencia en las prioridades políticas de los participantes. En esencia, cierto alineamiento de valores e intereses puede ser importante tanto para que las autoridades implicadas intenten coordinarse con una buena disposición inicial, como para que en última instancia puedan conseguirlo. Vid. AHDIEH, supra nota 143, en pág. 2108-10 (donde se describe la necesidad de equilibrio entre "perspectivas contrarias y complementarias"); Jack L. GOLDSMITH \& Eric A. POSNER, A Theory of Customary International Law, 66 U. Chi. L. Rev. 1113, 1122-23 (1999); cfr. Daniel C. ESTY, Revitalizing Environmental Federalism, 95 Mich. L. Rev. 570, 590-91 (1996) (que sugiere la necesidad de "normas medioambientales comunes" para conseguir la "COlaboración entre gobiernos descentralizados"). Conviene anotar, no obstante, que probablemente también es necesaria cierta coincidencia interna de intereses para el desarrollo de una política exterior federal efectiva. Así, incluso las políticas nacionales podrían ser difíciles de desarrollar en un Estado federal sin un cierto alineamiento de normas entre las comunidades y los individuos que lo component.

El segundo prerrequisito para el surgimiento de la gobernanza intersistémica es cierta dinámica de repetición en la que los entes subnacionales implicados entran en una interrelación recurrente. Vid. AHDIEH, supra nota 143, en pág. 2100. Se puede entender que esa recurrencia sirve a dos objetivos. Primero, puede promover una confianza que facilite el logro de la coordinación, incluso sin que existan mecanismos de coerción horizontal formalizados —o fácilmente utilizables-. Además, la repetición de papeles — especialmente en una amplia variedad de materias - puede fomentar intercambios beneficiosos, a medida que se agregan diferentes intereses y preferencias de los distintos participantes. Como el primer prerrequisito, también parece realmente probable que este segundo esté presente en el contexto subnacional de intereses que hemos analizado. Los estados federados y los entes locales en los Estados Unidos tienen mucho que decir al respecto.

162 Quisiera advertir que no creo que la gobernanza intersistémica sea universalmente aplicable o un modo efectivo de gobernanza. Al contrario, como he descrito en la Parte V, diversos factores hacen más o menos posible que sea aplicable y efectiva. Respecto al presente trabajo, mi objetivo se limita a sugerir que la gobernanza intersistémica puede ofrecer una aproximación útil a aspectos importantes de los asuntos exteriores y el derecho internacional.

163 Paul Berman describe varios hechos de una superposición reguladora de ese tipo, incluyendo el litigio por la venta de objetos nazis en Yahoo!, contraria al derecho francés. Vid. BERMAN, supra nota 11, en pág. 1160; vid. también id. en pág. 1192. 
mente después de la aprobación de la Ley Sarbanes-Oxley- ${ }^{164}$ se han visto obligados a compartir sus competencias sobre gobierno corporativo con el Congreso y la $\mathrm{SEC}^{165}$. El derecho medioambiental se caracteriza por una superposición similar, donde buena parte del desarrollo del derecho federal en la materia se realiza a través de diferentes iniciativas estatales y locales. Se podría decir que este federalismo "delegado" es la regla general en el moderno derecho medioambiental ${ }^{166}$.

Un segundo rasgo de la gobernanza intersistémica, de nuevo obvio tras el análisis anterior, es la centralidad de la coordinación. Quizás por la necesidad de responder a la superposición competencial creciente, diferentes modelos de coordinación competencial resultan cada vez más importantes en diferentes materias. Una manifestación de ello es la dinámica específica de la coordinación horizontal que aquí analizamos ${ }^{167}$. Pero el papel de la coordinación en la gobernanza intersistémica es, en última instancia, mucho mayor. De manera notable, opera también en sentido vertical, en la relación entre autoridades subnacionales, nacionales e, incluso, internacionales. Así, en un régimen de gobernanza intersistémica la coordinación representa la dinámica central en las relaciones institucionales más allá de los límites competenciales. Además, esta gobernanza también atribuye un papel a la coordinación por encima de la división público-privado, fomentando un mayor compromiso privado en las decisiones normativas y en su desarrollo ${ }^{168}$.

La tercera característica de los regímenes de gobernanza intersistémica es la interdependencia de entes reguladores independientemente constituidos. La propuesta de Robert Vover y Alexander Aleinikoff de que el desarrollo del proceso penal constitucional bajo el Tribunal Warren surgió de la interdependencia de los tribunales penales estatales y los tribunales federales inferiores en la resolución de las demandas de habeas corpus es un indicio de esta característica de la gobernanza intersistémica ${ }^{169}$. Cada conjunto de tribunales era formalmente independiente, de modo que los tribunales estatales podían dictar sentencias condenatorias sin apoyarse en la interpretación que los tribunales federales mantenían sobre el proceso penal constitucional, y los tribunales federales podían repetidamente admitir los recursos contra dichas sentencias. Aún hoy en día todos ellos son dependientes unos de otros de forma sistémica, dados los costes materiales (y, en última instancia, la inutili-

164 Sarbanes-Oxley Act of 2002, Pub. L. No. 107-204, 116 Stat. 745 (codificado en secciones dispersas del 11, 15, 18, 28, y 29 U.S.C.).

165 Vid. Robert B. AHDIEH, From Federal Rules to Intersystemic Governance in Securities Regulation, 57 EMORY L.J. 233, 237-40 (2007); Ahdieh, Rule 14a-8, supra nota 157; AHDIEH, supra nota 77, en pág. 872-75; Ahdieh, supra nota 83, en pág. 755-56.

166 Vid. BUZBEE, supra nota 82, en pág. 1565.

167 Vid. RESNIK, supra nota 5, en pág. 44, 47-48.

168 La elaboración negociada de normas y diversas formas de autorregulación supervisada son indicativas de esta posibilidad. Vid. Jody FREEMAN, The Private Role in Public Governance, 75 N.Y.U. L. REV. 543, 649-57 (2000).

169 Vid. COVER \& ALEINIKOFF, supra nota 143. 
dad) de intentar potenciar sus objetivos políticos sin atender unos a otros ${ }^{170}$. La interacción del anterior Fiscal General de Nueva York, Eliot Spitzer, y la SEC en la regulación de Wall Street es igualmente instructiva, dada la dependencia existente entre uno y otro para el logro de sus respectivos objetivos reguladores ${ }^{171}$.

Finalmente, los regímenes de gobernanza intersistémica suelen caracterizarse por atribuir un papel central a la persuasión en las actividades reguladoras, a diferencia de los modelos jerárquicos tradicionales de órdenes y control $^{172}$. En la gobernanza intersistémica, la calidad de la argumentación y el análisis resulta decisiva para determinar el efecto regulador ${ }^{173}$. Como hemos señalado, tradicionalmente se ha entendido el derecho como una fuente de respuestas claras y determinadas. Sin embargo, cada vez más el derecho puede ofrecer algo diferente $-\mathrm{y}$ quizás otra cosa- De forma creciente se puede entender el derecho como un punto de partida para el diálogo, como una declaración normativa y una aspiración. Aquí el derecho sirve a una función retórica, más que a una función determinativa, atributiva o prescriptiva. Aunque este derecho fuera "soft", no sería por ello menos importante. Al contrario, en la relación entre instituciones e intereses subnacionales, nacionales e internacionales, puede ser el medio esencial - el lenguaje operativo- de la interacción competencial ${ }^{174}$.

El voto concurrente del magistrado Stevens en Medellin v. Texas puede considerarse que sugiere precisamente esta dinámica. Ofreciendo su propia

170 Vid. AHDIEH, supra nota 143, en pág. 2090-91. Pueden observarse ciertas analogías con esta dinámica iterativa entre tribunales estatales y federales en la obligación que establece la Ley sobre las inversiones en Sudán (SADA) de que estados y entes locales comuniquen al Departamento de Justicia la aprobación de normas de desinversión que estén dentro del ámbito de actuación que les reconoce dicha ley. Vid. Sudan Accountability and Divestment Act of 2007, Pub. L. 110-174, 』3(c), 121 Stat. 2516. En esencia, esta última puede entenderse como un requisito procesal para obtener el conocimiento de las diversas medidas contra Sudán y eventualmente de lograr cierta interacción constructiva en su desarrollo.

171 Vid. AHDIEH, supra nota 77, en pág. 918-19.

172 Cfr. BERMAN, supra nota 11, en pág. 1236-37.

173 Vid. AHDIEH, Modern Jurisdiction, supra nota 157, en pág. 23-29; vid. también AHDIEH, supra nota 143, en pág. 2078, nota 214.

174 Con un objetivo similar, Alexander Aleinikoff ha analizado nuestras actuales concepciones sobre las "nociones modernas de soberanía y derecho". Vid. ALEINIKOFF, supra nota 154, en pág. 483. "Estas concepciones, que hunden sus raíces en ideas sobre el Estado-nación de hace varias centurias, ven el derecho como un producto de la soberanía que rige sobre un territorio y una población". Id. En este esquema conceptual, "el derecho que proviene de fuera del Estadonación" se ve como un "desafío a la soberanía". Id. Desde esta perspectiva, además, "resulta difícil ver las interacciones menos estructuradas como una fuente de 'derecho' o de normas". Id. en pág. 485. En relación a esto cita a Paul Berman: «alguien que estudie derecho internacional no encontrará "derecho" real porque estará buscando órdenes emanadas de una estructura jerárquica y basadas en el poder de la coerción. En cambio, una aproximación pluralista entiende que las interacciones entre diversos tribunales y autoridades reguladoras probablemente produzcan una calidad dialéctica que no es, ni la tradicional revisión jerárquica directa que ejercen los tribunales de apelación, ni simplemente el diálogo que con frecuencia se produce debido a la doctrina del acuerdo. BERMAN, supra nota 11, en pág. 1197. 
interpretación en la que hace compatibles la obligación internacional impuesta por la decisión del TIJ en el caso Avena y la consideración mayoritaria de que las obligaciones del tratado no son auto-ejecutivas, Stevens concluye que "la decisión de que es 'vinculante' desde el punto de vista del derecho internacional no establece nada sobre los efectos jurídicos nacionales" ${ }^{175}$. En esta diferenciación entre ser vinculante y producir efectos, de forma clara, la utilización del derecho podría parecer que sugiere de éste algo diferente de lo tradicional.

Un efecto similar tiene la atención que el magistrado Stevens dedica al Estado de Tejas ${ }^{176}$. Habiendo sido Tejas quien causó el caso Medellín, por no procurar al demandado la información sobre su derecho de protección consular, Stevens insiste en que corresponde por ello también a Tejas la resolución del caso. ${ }^{177}$ No existe texto constitucional ni doctrina judicial que se pueda citar para apoyar esta decisión. Precisamente, la cuestión central en la decisión de Medellín es que no existe esa obligación jurídica de Tejas. Sin embargo, para Stevens la obligación de Tejas no es menos deber porque no exista un fundamento explícito. Su fuerza simplemente descansa en motivos de persuasión ${ }^{178}$.

\section{IV.2. El PAPEL NACIONAL EN LA GOBERNANZA INTERSISTÉMICA DE LOS ASUNTOS EXTERIORES Y EL DERECHO INTERNACIONAL}

Habiendo señalado las características generales de la gobernanza intersistémica, corresponde ahora analizar el papel que pueden desarrollar las autoridades nacionales en un esquema intersistémico de autoridades subnacionales, nacionales e internacionales en materia de asuntos exteriores y derecho internacional. Si la coordinación horizontal entre gobiernos subnacionales es una fuente valiosa de coordinación en esta materia, tal y como hemos visto antes, ¿qué papel corresponde a las autoridades nacionales? Existen unas cuantas posibilidades al respecto.

175 Medellín v. Texas, 128 S. Ct. 1346, 1374 (2008) (voto concurrente del magistrado Stevens). Es más, la intervención del magistrado Stevens sobre el compromiso de los Estados Unidos para hacer cumplir las decisiones del TIJ puede entenderse en un sentido similar. Vid. id. en pág. 1373.

176 Vid. id. en pág. 1375.

177 Vid. id.

178 Merece la pena señalar una última nota definitoria de la gobernanza intersistémica. A pesar de que aquí se ha puesto el énfasis en la actuación de autoridades públicas subnacionales, nacionales e internacionales, importantes elementos de la teoría que he expuesto van más allá de la esfera pública. Se podría decir, de hecho, que entre los rasgos más notables de los cambios en la gobernanza que yo destaco se encuentran las cada vez más numerosas formas privadas de regulación pública y la creciente dimensión pública de conductas privadas. Esto es lógico dado mi énfasis en las dinámicas del establecimiento de estándares. Como ya se ha señalado, los entes privados han desempeñado un papel importante en los procesos globales de estandarización, como, por ejemplo, el Internet Engineering Task Force y la International Organization for Standardization. El presente trabajo se centra en la "cara pública de la moneda" — dada la necesidad de teorizar la dinámica que funciona entre instituciones públicas - pero el papel de los "reguladores" privados exige también una mayor atención. Vid. FREEMAN, supra nota 168. 
Para empezar, las autoridades nacionales desempañan un papel importante al asegurar que los sistemas de coordinación horizontal entre entes subnacionales operen libremente. Los prejuicios contra Estados federados y entes locales participantes en redes por parte de no participantes pueden restar eficacia a la coordinación, mientras que los abusos contra no participantes cometidos por miembros de esas redes pueden generar una coordinación excesiva ${ }^{179}$. Por ello, las normas federales pueden ser decisivas para prevenir conductas abusivas, tanto de participantes como de no participantes en las redes.

Un papel menos obvio atribuible a la regulación desde el nivel nacional surge de la posibilidad de producir efectos de cierre, allí donde la coordinación horizontal la fomentan las externalidades de las redes y las dinámicas resultantes de los juegos de coordinación. En conjunto, dos fenómenos pueden fomentar ese efecto de cierre: primero, la relativamente fuerte preferencia por la coordinación en ciertas circunstancias, y, segundo, el hecho de que el tamaño cuente en la maximización de la eficiencia de las redes ${ }^{180}$. Debido a estos fenómenos, puede ser relativamente difícil eliminar estructuras de coordinación de nivel inferior al óptimo y elecciones políticas ineficientes por parte de redes dominantes ${ }^{181}$. Es muy difícil lograr que se produzca un cambio si se da una visión excesivamente individualista sobre la coordinación y existe el miedo a no participar en una red de coordinación dominante ${ }^{182}$.

A la luz del potencial de cara a este efecto de cierre, se puede identificar otro posible papel nacional, el de ayudar a determinar las expectativas de las autoridades subnacionales ${ }^{183}$. De forma específica, las autoridades nacionales

179 También se puede imaginar el papel de las autoridades nacionales regulando el trato de las redes a sus propios miembros. Cfr. Madhavi SUNDER, Cultural Dissent, 54 Stan. L. Rev. 495 , 566 (2001) (que señala la possible complicidad del derecho en permitir a los "líderes culturales tradicionales silenciar el desacuerdo interno dentro de asociaciones culturales").

180 Vid. AHDIEH, supra nota 7, en pág. 223-26; Robert B. AHDIEH, Making Markets: Network Effects and the Role of Law in the Creation of Strong Securities Markets, 76 S. Cal. L. Rev. 277, 296-322 (2003).

181 El dominio de Microsoft Windows, del teclado QWERTY y de diversos DVD, HDTV, así como de otros estándares se ha considerado el resultado de externalidades de redes, que producen un fuerte "efecto pronóstico" frente a una red individual, una vez que uno ha puesto una pesada carga sobre sus competidores. Vid. Stanley M. BESEN \& Joseph FARRELL, Choosing How to Compete: Strategies and Tactics in Standardization, J. Econ. Persp., Spring 1994, en pág. 117, 118; vid. también Michael L. KATZ \& Carl SHAPIRO, Systems Competition and Network Effects, J. Econ. Persp., Spring 1994, en pág. 93, 105-06.

182 Conviene hacer notar, por otro lado, que hay límites compensatorios significativos en la fuerza que tienen los efectos de las redes y las dinámicas de los juegos de coordinación en los modelos de coordinación horizontal entre estados y entes locales; ello se debe tanto al número relativamente limitado de participantes como a cierta habilidad para participar activamente en diversas redes. Vid. Mark A. LEMLEY \& David MCGOWAN, Legal Implications of Network Economic Effects, 86 CAL. L. REV. 479, 599 (1998) (señalando la importancia de la "exclusividad" en la producción de externalidades de redes).

183 En los juegos de coordinación, a diferencia del más familiar, el juego del dilema del prisionero, la eficacia en los resultados depende, no de la alteración de los incentivos de los jugadores, sino de sus expectativas. Vid. Richard H. MCADAMS, A Focal Point Theory of Expres- 
pueden ayudar a superar los efectos de cierre actuando para mejorar la credibilidad de elecciones políticas alternativas o incluso de redes alternativas. En un caso extremo, pueden hacer esto por medio de la "preención" federal. En este último caso, naturalmente, la coordinación de jure elimina el establecimiento de estándares de grupo/coordinación como mecanismo operativo de alineamiento político. Pero otras intervenciones mucho más limitadas pueden ser suficientes para lograr resultados eficaces, dado el cambio en las expectativas, más que en los incentivos, que es el modo necesario de conseguir la coordinación que conduce a los efectos de cierre antes descritos.

En este sentido, en otro lugar he propuesto un papel relativo a "normas reguladoras" no coercitivas, el de ayudar a superar redes cerradas y situaciones similares ${ }^{184}$. Esta función se concreta en reducir lo más sobresaliente de una red dominante o de una elección política. Así, las normas reguladoras ofrecen distintos puntos de vista para una potencial coordinación, facilitando el alejamiento de una posición ineficiente ${ }^{185}$. De forma significativa, sin embargo, para ello estas normas reguladoras no necesitan que se impongan unos resultados coordinados, como en la coordinación de jure. Considérese, por ejemplo, la Liga Nacional de Ciudades (NLC). Las autoridades nacionales competentes pueden reconocer y comprometerse activamente con una red de entes locales que vaya a competir con aquella, quizás negociando políticas en juego o mediante la asignación de ayudas o subsidios; aún así, puede quedar un largo camino hasta que sea posible que ésta compita efectivamente con la $\mathrm{NLC}^{186}$. En el caso de decisiones políticas sensibles, la convocatoria de reuniones sobre alternativas políticas, la distribución de documentación relevante, y otros mecanismos similares de carácter no coercitivo pueden servir para reducir el "cierre" de una decisión política ya tomada en una red horizontal de actores subnacionales.

En el nivel más general, finalmente, podemos identificar otro papel para las autoridades nacionales, el de ayudar a contextualizar la búsqueda de redes horizontales de actores subnacionales, de un modo similar al "método abierto de coordinación" (open method of coordination - OMC) y a mecanis-

sive Law, 86 VA. L. REV. 1649, 1657 (2000) ("La resolución de los problemas de cooperación exige un cambio en los beneficios que se obtienen. La resolución de los problemas de coordinación, sin embargo, exige el justo tipo de expectativas"); Robert E. SCOTT, The Limits of Behavioral Theories of Law and Social Norms, 86 VA. L. REV. 1603, 1622, nota 40 (2000) ("En el caso de los juegos de coordinación, de forma ideal el derecho ayuda a resolver el problema modificando las expectativas de los participantes (más que sus incentivos)...."). Dada la ausencia de cualquier incentivo que se pueda abandonar, incluso desde un equilibrio que sea menor que el óptimo, la necesidad crítica es alinear las expectativas de los participantes (p. ej., dónde me buscarás si estamos separados en Nueva York; por qué lado de la calzada vas a circular; te apartarás antes del impacto en el juego de los pollitos).

184 Vid. AHDIEH, supra nota 7, en pág. 245-55.

185 Vid. Randal C. PICKER, Simple Games in a Complex World: A Generative Approach to the Adoption of Norms, 64 U. CHI. L. REV. 1225, 1284-85 (1997) (que describe el mecanismo de "producción de normas" por entes públicos, semejante a las normas regulatorias).

186 Vid. AHDIEH, supra nota 7, en pág. 301-02 (donde elabora un mecanismo por el cual las autoridades públicas pueden ayudar a desplazar redes ineficientes). 
mos semejantes de gobernanza multinivel que funcionan en Europa ${ }^{187}$. En estos casos, las autoridades de la Unión Europea establecen puntos de referencia, incluyendo indicadores cualitativos y cuantitativos. La implementación de esos estándares se realiza a nivel nacional. Y, por último, el control y la supervisión de esa implementación tiene lugar en diferentes niveles ${ }^{188}$.

En la dinámica de la coordinación horizontal en materia de asuntos exteriores y derecho internacional, se puede imaginar una estructura análoga en la que autoridades nacionales identifiquen como prioridades ciertos asuntos, o quizás incluso determinen que debe lograrse cierta política coordinada. Sin embargo, la estrategia elegida para ello, que quizás incluya el alcance de la coordinación a lograr y su objetivo concreto, podría dejar a las autoridades subnacionales que operasen a través de diferentes estructuras de coordinación horizontal ${ }^{189}$.

Naturalmente, éste es solo uno de los muchos posibles caminos de la gobernanza intersistémica. Resulta indicativo, no obstante, de la enorme variedad de estructuras institucionales $-\mathrm{y}$ de diferentes concepciones del derecho- que se encuentran en la esencia de la gobernanza intersistémica. Como ha mostrado el sistema de la OMC, y se puede afirmar de los regímenes de gobernanza intersistémica en general: «en muchos aspectos el método abierto de la coordinación es... una tercera vía entre la 'integración pura' y la lógica de la cooperación intergubernamental genuina. Más abierta y menos rígida que la primera, la OMC es también más ambiciosa y está mejor estructurada que la segunda" ${ }^{190}$.

\section{IV.3. Modelos anÁlogos a la GobernanZa InTERSistémica en ASUntos EXTERIORES Y DERECHO INTERNACIONAL}

Una vez que hemos señalado los elementos esenciales de los regímenes de gobernanza intersistémica y las diferentes formas en que las autoridades nacionales pueden contribuir en estos regímenes no jerárquicos de superposición competencial, podemos conocer algo más de la naturaleza de los mismos si analizamos modelos similares de regulación en otros ámbitos. La similitud con el método abierto de coordinación de Europa, citado anteriormente, muestra ciertos rasgos potenciales de una dinámica de gobernanza intersisté-

187 Vid. Gráinne DE BÚRCA, The Constitutional Challenge of New Governance in the European Union, 28 EUR. L. REV. 814, 815-16, 825 (2003); David M. TRUBEK \& Louise G. TRUBEK, Hard and Soft Law in the Construction of Social Europe: The Role of the Open Method of Coordination, 11 EUR. L.J. 343 (2005).

188 Vid. DE BÚRCA, supra nota 187, en pág. 825.

189 Para ser claros, esta aproximación implica algo más que la simple promoción en el nivel de la Unión Europea. Funciona realmente. El elemento esencial es simplemente la delegación de poderes de implementación, y la flexibilidad resultante en esa fase.

190 Renaud DEHOUSSE \& Jean MONNET, The Open Method of Coordination: A New Policy Paradigm?, Trabajo presentado al First Pan-European Conference on European Union Politics, Sept. 26-28, 2002, en pág. 4 (nota a pie omitida). 
mica en asuntos exteriores y derecho internacional, incluyendo el establecimiento de puntos de referencia y mecanismos organizados de retroalimentación. Europa también ofrece otras potenciales referencias, incluyendo su estructura de comités y la doctrina del margen de apreciación elaborada por el Tribunal Europeo de Derechos Humanos (TEDH). Con la primera, la Comisión Europea consigue la aceptación y el apoyo de los gobiernos nacionales antes de que se adopten las medidas de ejecución correspondientes utilizando un conjunto de comités integrados por representantes de los Estados miembros $^{191}$. Por su parte, mediante el segundo, el TEDH ha permitido un margen de diferenciación en la aplicación nacional de las normas europeas — dentro del margen de apreciación permitido— ${ }^{192}$. Estructuras y regímenes de discrecionalidad similares pueden ser útiles en las relaciones entre instituciones e intereses subnacionales, nacionales e internacionales en materia de asuntos exteriores y derecho internacional.

Aún podemos hacernos una idea mayor del potencial de la gobernanza intersistémica en dicha materia si analizamos el papel que desempeñan las provinciales canadienses en los asuntos exteriores de Canadá. Estas provincias - tanto por razones de derecho como de costumbre- son muy activas en cuestiones relativas a asuntos exteriores: participan en la negociación de acuerdos internacionales, tanto de forma directa como indirecta, e influyen de manera significativa en las posiciones que adoptan las autoridades federales en comercio internacional y otras cuestiones similares. Como han descrito gráficamente dos observadores:

"Québec, Alberta y Ontario mantienen importantes oficinas políticas y económicas en Europa, la Costa del Pacífico y los Estados Unidos; la Columbia Británica facilita la venta de carbón a Japón; y el gobierno de Alberta ayuda a vender el gas natural y el petroleo a los Estados Unidos.

Estas cuatro provincias canadienses son actores internacionales. Diseñan y desarrollan políticas comerciales internacionales, promueven exportaciones, buscan y reciben inversiones extranjeras, llevan negociaciones para intercambios económicos y culturales con gobiernos extranjeros, controlan de manera independiente actividades nacionales en otros países, y presionan a gobiernos extranjeros. En el caso de estas cuatro provincias, las administraciones y presupuestos dedicados a asuntos internacionales son sustanciales. Y, aunque algunas veces actúan internacionalmente de acuerdo con el Gobierno federal de Canadá, con frecuencia actúan en solitario" ${ }^{193}$.

191 Vid. Francesca BIGNAMI, Creating European Rights: National Values and Supranational Interests, 11 Colum. J. Eur. L. 241, 310-11 (2005).

192 Vid. Laurence R. HELFER \& Anne-Marie SLAUGHTER, Toward a Theory of Effective Supranational Adjudication, 107 YALE L.J. 273, 316-17 (1997); vid. también BERMAN, supra nota 11, en pág. 1201-03.

193 Elliot J. FELDMAN \& Lily Gardner FELDMAN, Canada, en federalism and international relations: the role of subnational units 176, 176 (Hans J. MICHELMANN \& Panayotis SOLDATOS eds., 1990). 
Así pues, estas provincias actúan en las relaciones internacionales de Canadá de un modo en que los Estados federados y los entes locales de los Estados Unidos tradicionalmente no lo han hecho.

Este modelo que ofrece Canadá se aproxima al que se puede encontrar en la decisión del Tribunal Supremo en Medellín v. Texas —en el que el Estado de Tejas aparece como el sujeto que debe decidir los efectos nacionales del derecho internacional ${ }^{194}$. Como en los Estados Unidos, el Gobierno federal de Canadá tiene la competencia exclusiva para vincular al Estado internacionalmente. No obstante, al menos cuando se trata de cuestiones que materialmente corresponden a las provincias, la aprobación de la legislación nacional que desarrolle una obligación internacional en la materia se deja a las provincias ${ }^{195}$. Este régimen —un mecanismo del acceso gradual de Canadá a la soberanía independiente- también ha recibido las críticas de los que han presionado para que existiera solo «una voz" en la política exterior de Canadá196. Pero aún así el sistema se ha mantenido.

Recientes pasos dirigidos a la ratificación canadiense de la Convención ICSID (Convention on the Settlement of Investment Disputes between States and Nationals of Other States-ICSID) sugiere la dinámica tan diferente entre autoridades subnacionales y nacionales que suscita el sistema canadiense. Con mucho bombo, en marzo de 2008 el Parlamento federal canadiense aprobó la legislación de desarrollo de la ICSID que atribuía al Gobierno federal la competencia para ratificar ese tratado ${ }^{197}$. Pero esa ratificación requería la autorización de todas las provincias, y a día de hoy sólo la habían concedido cuatro de ellas ${ }^{198}$. Así pues, el Gobierno federal ha enviado una "invitación" a las provincias restantes para que adopten las normas que correspondan ${ }^{199}$.

Naturalmente, un régimen como éste puede resultar muy problemático. El riesgo de que surjan problemas por la resistencia de algunos miembros es sustancial al mismo ${ }^{200}$. Se pueden considerar algunos mecanismos para reducir esta posibilidad, pero no serían infalibles. Sin embargo, este régimen ofrece importantes lecciones para el diseño de los asuntos exteriores y el derecho

194 Vid. supra notas $175-78$ y el texto que las acompaña.

195 Vid. Fabien GELINAS, The Constitution of Agreement: A Brief Look at SubFederal CrossBorder Cooperation, 2006 Mich. St. L. Rev. 1179, 1186.

196 Vid., p. ej., Jeffrey L. FRIESEN, Note, The Distribution of Treaty-Implementing Powers in Constitutional Federations: Thoughts on the American and Canadian Models, 94 Colum. L. Rev. 1415, 1434-35 (1994).

197 Vid. Orlando SILVA, Feds Near Ratification of ICSID - Important Tool for Canadian Investors Abroad, Mondaq Bus. Briefing, Apr. 8, 2008.

198 Vid. Id.

199 Vid. David DITTMAN, This One Goes to Eleven, Maple Leaf Memo, Apr. 4, 2008, en pág. 3, available at http://naftatrustclaims.com/sitebuildercontent/sitebuilderfiles/dittman_nafta_04_04_08. pdf.

200 Cfr. John O. MCGINNIS, The Appropriate Hierarchy of Global Multilateralism and Customary International Law: The Example of the WTO, 44 Va. J. Int'l L. 229, 250 (2003). 
internacional en el mundo complejo de la gobernanza intersistémica. Quizás, dada la alta participación en determinadas áreas, sea suficiente con que las estructuras institucionales conciten un amplio acuerdo, si no necesariamente el consenso.

Finalmente, volviendo a nuestros ejemplos de la política sancionadora a Sudán y de Medellín, en ellos también encontramos más indicios sobre cómo puede funcionar una dinámica de gobernanza intersistémica entre autoridades subnacionales, nacionales e internacionales en el ámbito de los asuntos exteriores. Para empezar, el ejemplo de Sudán ilustra la cualidad dialéctica de las interacciones en el caso $^{201}$. Después de que Illinois aprobase su legislación sobre desinversiones, el Consejo Nacional del Comercio Exterior (NFTC), un grupo nacional de intereses, la recurrió ante un tribunal federal. Illinois defendió su legislación, pero incluso mientras hacía esto, apoyaba los esfuerzos de sus representantes en el Congreso para que se aprobase allí una legislación federal que autorizase su actuación. Cuando la NFTC ganó en el tribunal de distrito, Illinois retiró la legislación que había aprobado, aunque sólo para sustituirla por una versión revisada después de que la SADA autorizase iniciativas estatales y locales similares.

Parece probable que esta dinámica repetitiva persista. No hay, como tal, un punto de ruptura obvio en el modelo dialéctico de interacción. Queda ver de qué manera responderán otros estados y entes locales a la nueva legislación federal. ¿Aprobarán sanciones estatales dada la autorización del Congreso para ello o el momento político que generó esta situación ha pasado ya? Lo ultimo, naturalmente, es lo que más probablemente mostraría hasta donde SADA puede ser un precedente. ¿Aparecerá en el futuro una autorización similar para que los estados y entes locales puedan aprobar medidas sancionadoras? Por último, si esto ocurre ¿el alcance de la autorización será similar al de SADA, más limitado o, quizás, mayor?202

El ejemplo de Medellín es del mismo modo instructivo; nos muestra especialmente cómo la interacción entre autoridades subnacionales, nacionales e internacionales en un régimen de gobernanza intersistémica pueden resultar muy diferente de lo que se espera. La respuesta inicial del Estado de Tejas a la decisión del TIJ, a pesar de la petición del Presidente de que se cumpliera dicha decisión, fue resistirse a la aplicación del derecho internacional. Es útil recordar la respuesta tan diferente del Estado de Oklahoma.

Casi inmediatamente después de Avena, sucedió lo que la mayoría de los observadores ha calificado como una sorpresa considerable: el tribunal penal de apelación de Oklahoma, apoyándose en la decisión del TIJ, ad-

201 Cfr. BERMAN, supra nota 11, en pág. 1197; Janet Koven LEVIT, A Tale of International Law in the Heartland: Torres and the Role of State Courts in Transnational Legal Conversation, 12 Tulsa J. Comp. \& Int'l L. 163, 178, 180 (2004) (en el que describe el derecho internacional como un "proceso iterativo").

202 Conviene señalar que SADA solo autoriza un conjunto limitado de medidas estatales y locales, pero no abre la puerta a cualquier tipo de iniciativa que los estados o los entes locales puedan adoptar contra los estados que sean su objetivo. 
mitió la petición de uno de los demandantes del caso Avena de obtener una vista conforme a su demanda basada en la Convención de Viena. ${ }^{203}$ Esto provocó que el Gobernador suspendiera la ejecución de la pena de muerte. ${ }^{204}$ Se pueden ofrecer numerosas interpretaciones de la decisión de Oklahoma. Pero al menos pone de manifiesto la complejidad de los modelos de interacción institucional que pueden surgir cuando las autoridades subnacionales actúan en el ámbito de los asuntos exteriores y el derecho internacional.

El caso del tribunal penal de apelación de Oklahoma también plantea la cuestión de cómo puede decidir actuar Tejas después de la decisión del Tribunal Supremo. Según ha insistido el magistrado Stevens, con la decisión de Medellin, el cumplimiento por parte de los Estados Unidos de sus obligaciones conforme a la Convención de Viena en materia de relaciones consulares ha quedado en manos de Tejas ${ }^{205}$. En realidad, Tejas ha decidido mantener su posición, sin tener en cuenta la decisión de Medellín de 8 de agosto de 2008. ¿Cómo podría haber actuado de otra manera en un régimen de gobernanza intersistémica?

En un reciente artículo, Alexander Aleinikoff sugiere una posibilidad ${ }^{206}$ relacionada con el voto particular del magistrado Breyer en otro caso relativo a la Convención de Viena, el asunto Sánchez-Llamas v. Oregon ${ }^{207}$. Para empezar, Breyer admite que la interpretación del TIJ sobre la Convención ${ }^{208}$ no vincula al Tribunal Supremo. No obstante, habiendo reconocido esto, entiende que existe un deber del Tribunal de "considerar con respeto" la decisión del TIJ. ${ }^{209}$ Más que hacer suya la decisión del TIJ, apoyada en una mayoría estrecha y claramente objetable, el magistrado Breyer realizó una interpretación más próxima a toda la amplia jurisprudencia del TIJ. Sirviéndose del análisis de ésta, en cambio, ofreció una lectura más próxima a la decisión del TIJ, que el Tribunal podría haber elegido para aplicar en los Estados Unidos.

En opinión de Aleinikoff, esto representa una aproximación funcional al deber de "considerar con respeto" reconocido en el asunto Sánchez-Llamas ${ }^{210}$. Y desde una perspectiva más amplia, indica un esquema general de interacción entre instituciones nacionales e internacionales. De acuerdo con este esquema, el derecho internacional no es ni derecho vinculante, ni simple-

203 Torres v. Oklahoma, No. PCD-04-442, 2004 WL 3711623, at*1 (Okla. Crim. App. May 13, 2004); vid. también Levit, supra nota 200, en pág. 171-72.

204 Vid. Oklahoma Court Halts Execution, Augusta Chron., May 14, 2004, at A14. La naturaleza discutible de la decisión de Oklahoma se muestra más claramente si la comparamos con la decisión del Estado de Virginia de proceder a la ejecución de Angel Francisco Breard, a pesar de la solicitud del TIJ de suspender la ejecución y del ruego de la Secretaría de Estado de los Estados Unidos al Gobernador de Virginia para que admitiera esa solicitud. Vid. supra nota 52.

205 Vid. supra notas 175-78 y el texto que las acompaña.

206 Vid. ALEINIKOFF, supra nota 154.

207548 U.S. 331 (2006).

208 LaGrand Case (F.R.G. v. U.S.), 2001 I.C.J. 466 (June 27).

209 Vid. Sanchez-Llamas, 548 U.S. en 601-02 (voto particular del magistrado Breyer, J).

210 Vid. ALEINIKOFF, supra nota 154, en pág. 482-83. 
mente material con el que llenar muchas $\operatorname{citas}^{211}$. Resulta central para el análisis, pero no totalmente determinante. La actuación de tribunales nacionales en materia de derecho internacional, en suma, resulta "moderada, respetuosa y con capacidad para adaptarse ${ }^{212}$. Esto mismo es lo que se espera en la actuación de regímenes de gobernanza intersistémica.

\section{EL TIEMPO, LUGAR Y LÍMITES DE LA GOBERNANZA INTERSISTÉMICA}

Así pues, los modelos de gobernanza intersistémica pueden tener un papel cada vez más importante en la interacción entre instituciones subnacionales, nacionales e internacionales. Antes de concluir, sin embargo, sería útil tener en cuenta qué factores pueden hacer que este papel sea más o menos apropiado en un caso concreto. Para realizar este análisis, comenzaré señalando algunos de los motivos normativos que justifican adoptar la gobernanza intersistémica. A pesar de que este tipo de gobernanza sea atractiva con carácter general, es importante considerar en qué casos es probable que resulte pertinente o útil. ¿Cuándo podemos adoptar un régimen de gobernanza intersistémica frente a las alternativas de la relación jerárquica o la dinámica del mercado? Por último, el otro lado de la moneda ¿qué debemos saber sobre las debilidades o defectos de la gobernanza intersistémica?

\section{V.1. LA PROMESA NORMATIVA DE LA GOBERNANZA INTERSISTÉMICA}

Al menos de entrada, el análisis normativo de la gobernanza intersistémica se centra en cuestiones procesales ${ }^{213}$. La perspectiva determinante se refiere al diseño institucional ${ }^{214}$. La utilidad de la gobernanza intersistémica no se puede valorar - al menos de entrada - por el logro de resultados materiales predeterminados $^{215}$. En tal caso, su análisis se refiere más a cuestiones de legitimidad y responsabilidad, lo que ya es en sí un logro.

211 Vid. id. en pág. 482.

212 Id.

213 En esto, nos hacemos eco del análisis de Berman sobre el "pluralismo jurídico global", que aspira no al acuerdo sobre normas, sino más bien sobre "mecanismos procesales, instituciones y prácticas". Vid. BERMAN, supra nota 11, en pág. 1164-67 (que señala que el pluralismo jurídico global no propone una jerarquía de normas y valores).

214 Se puede entender así que el estudio de la gobernanza intersistémica cae dentro de la órbita de la teoría organizacional. Cfr. Herbert A. SIMON, Administrative behavior: a study of decision-making processes in administrative organization (2d ed. 1957).

215 En cierto sentido, las dinámicas de coordinación son neutrales respecto a los resultados materiales. La elección de determinadas normas como preferentes dentro de un esquema de coordinación puede por ello ser discutida. Desde la perspectiva de la teoría de los juegos, los equilibrios de coordinación son estables, pero no necesariamente óptimos. Vid. AHDIEH, supra nota 7, en pág. 236-37. Como sugiero más adelante, ésta surge como posible crítica de un régimen de coordinación de gobernanza intersistémcia en las relaciones entre instituciones subnacionales, nacionales e internacionales. Vid. infra nota 260 y el texto que la acompaña. 
En esencia, la gobernanza intersistémica da cuenta de en qué medida nuestras instituciones reguladoras logran los objetivos que les hayamos fijado. La superposición, la coordinación, la interdependencia y la persuasión que caracterizan los regímenes de gobernanza intersistémica se refieren a la capacidad de las instituciones reguladoras implicadas de cumplir con los mandatos que se les hayan asignado. Tal y como se afirma en la creciente bibliografía sobre la nueva gobernanza ${ }^{216}$, con carácter general una eficiencia procesal de este tipo permite esperar que se logren los resultados buscados, y parece razonablemente probable que se haga de un modo legitimado y responsable. Realmente, la gobernanza intersistémica va dirigida a la eficacia fundamental de nuestras instituciones públicas —a los medios por los cuales el diseño y el proceso institucional pueden organizarse del mejor modo posible para servir a la consecución de los fines políticos deseados-.

Mis propias valoraciones de la utilidad normativa de la gobernanza intersistémica comienzan con las explicaciones de Robert Cover sobre la "redundancia o superposición jurisdiccional". Frente a la crítica extendida de la jurisdicción expansiva de los tribunales federales, Cover revela beneficios compensatorios de la superposición jurisdiccional de tribunales federales y estatales ${ }^{217}$. De manera específica señala su potencial para reducir la búsqueda por parte de los jueces de su propio interés ${ }^{218}$ y la promoción de sus preferencias ideológicas o de otro tipo ${ }^{219}$. Además, Cover destaca la capacidad de esa redundancia o superposición para fortalecer la innovación judicial ${ }^{220}$.

En el análisis jurídico tradicional, la redundancia - la "superposición", como yo la he caracterizado - ha sido fuertemente combatida, dada la concepción del derecho como "categorización, definición clara y delimitación" ${ }^{221}$. Desde el punto de vista del último elemento, la gobernanza intersistémica es un problema que debe resolverse. Sin embargo, para valorar los regímenes de gobernanza intersistémica, es importante conocer ciertos beneficios de esa superposición.

En primer lugar, los regímenes de gobernanza intersistémica pueden ayudar a un alineamiento mayor del derecho y la regulación con la identidad funcional de los sujetos de la regulación, ya sean instituciones que combinen el carácter nacional con vínculos locales concretos - un caso entre el creciente número de aquellos en los que se dan cuestiones regulatorias en las que se produce un solapamiento competencial - o ya sean otros casos de este tipo. Frente a este tipo de sujetos y cuestiones, un régimen regulador singular y aislado, apoyado en una única jurisdicción, es necesariamente de menor eficacia. Desde el punto de vista de la regulación, demostraría no per-

216 Vid. supra nota 8.

217 Vid. Robert M. COVER, The Uses of Jurisdictional Redundancy: Interest, Ideology, and Innovation, 22 Wm. \& Mary L. Rev. 639 (1981); vid. también BERMAN, supra nota 11, en pág. 1210-11.

218 Vid. COVER, supra nota 217, en pág. 658-59.

219 Vid. id. en pág. 664.

220 Vid. id. en pág. 672-73.

221 Vid. AHDIEH, supra nota 77, en pág. 867. 
mitir encajar correctamente diferentes elementos, y las instituciones estarían tratando de regular sujetos y cuestiones de naturaleza distinta a la suya.

Otro aspecto de las consecuencias positivas de la gobernanza intersistémica para la identidad es el relativo a la influencia variada de distintos tipos de grupos de intereses actuando en distintos niveles de gobierno. Dada esta variedad —señalada en derecho societario, derecho medioambiental y en otras ramas del derecho——222 la gobernanza intersistémica podría servir para desempeñar una especie de función "ponderadora" ${ }^{223}$. En esencia, podría ofrecer una ventaja desde el punto de vista de la economía política, ya que todas las voces implicadas en una determinada cuestión política podrían ser totalmente escuchadas e integradas.

Además, es previsible que una cierta dinámica de competencia reguladora en los regímenes de gobernanza intersistémica pueda reducir modelos de inercia y potenciar una deseable innovación reguladora ${ }^{224}$. Tal y como Cover y Aleinikoff han descrito, la posición inevitable de los tribunales estatales y federales conforme a la jurisprudencia del Tribunal Warren les ha forzado a moverse de sus posiciones iniciales y sus interpretaciones sobre el proceso penal constitucional, conociendo e integrando las posiciones del otro ${ }^{225}$. En este sentido, se fomentó un proceso que generó innovación y en el que tanto los tribunales federales como los estatales participaron totalmente. Una dinámica semejante de innovación también puede encontrarse en la regulación federal y estatal del mercado de valores, y quizás en la superposición de recursos federales y estatales en materia de derechos civiles ${ }^{226}$. Una contribución de este tipo, que reduce la inercia y fomenta la innovación, puede ser realmente importante. El derecho y la regulación tienen una tendencia natural al mantenimiento del status quo y una resistencia también natural al cambio ${ }^{227}$. Los esquemas institucionales que reducen la tendencia a mantener el status quo y fomentan el cambio probablemente tengan un valor significativo.

Finalmente, debemos señalar un último beneficio: la habilidad de la gobernanza intersistémica para promover una integración beneficiosa. La innovación, y la variedad que la acompaña, son deseables en muchos casos, pero no siempre es así. Tomemos como ejemplo el ámbito de los derechos humanos, en el que nos hemos comprometido con un cierto universalismo. Aquí,

222 Vid., p. ej., Claire A. HILL \& Brett H. MCDONNELL, Disney, Good Faith, and Structural Bias, 32 J. corp. 1. 833, 848 (2007).

223 Una posibilidad al respecto es que las autoridades subnacionales puedan tener una mayor capacidad para garantizar el cumplimiento de ciertas obligaciones internacionales — como California y las normas sobre cambio climático, por ejemplo-, dada la potencial concentración de intereses nacionales en juego dentro de una jurisdicción.

224 Cfr. John C. YOO, Sounds of Sovereignty: Defining Federalism in the 1990s, 32 IND. L. REV. 27, 37 (1998).

225 Vid. COVER \& ALEINIKOFF, supra nota 143, en pág. 1049-50.

226 Vid. AHDIEH, supra nota 77, en pág. 885-88, 891.

227 Vid. Clayton P. GILLETTE, Lock-In Effects in Law and Norms, 78 B.U. L. Rev. 813 (1998); Oona A. HATHAWAY, Path Dependence in the Law: The Course and Pattern of Legal Change in a Common Law System, 86 Iowa L. Rev. 601 (2001). 
más que innovación, el objetivo es la armonización del derecho y la regulación. No obstante, la gobernanza intersistémica también puede ser útil para ello. Puede ofrecer un mecanismo para establecer modelos de integración de mayor tamaño y relativamente no invasivos. Es previsible que la imposición vertical de estándares de armonización genere una cierta resistencia, incluso aunque se realice en los términos más universales. Por el contrario, la gobernanza intersistémica puede ofrecer una vía para que los distintos ámbitos competenciales integren gradualmente normas universales, cada uno en sus propios términos. Con esto no pretendo socavar la utilidad de la gobernanza intersistémica como mecanismo de innovación, ni el margen que crea para la variedad y el pluralismo, frente a la armonización. Simplemente, quiero señalar que en los casos en los que la armonización es beneficiosa, la gobernanza intersistémica puede ofrecer un mecanismo efectivo para lograrla.

\section{V.2. LOS INDICADORES DE LA GOBERNANZA INTERSISTÉMICA}

La gobernanza intersistémica, por tanto, puede tener una utilidad significativa. Contrariamente al tradicional saber y entender, no es preciso renegar, enfrentarse o eliminar la superposición y la complejidad. Éstas incluso merecen la pena. En este sentido, es necesario tener en cuenta en qué contextos la gobernanza intersistémica puede resultar más beneficiosa o efectiva, por comparación con las alternativas de la relación jerárquica o la dinámica no coordinada del libre mercado. ¿Qué indicadores pueden marcar que sea más o menos probable que se utilice la gobernanza intersistémica y que genere los beneficios antes señalados?228

Un conjunto claro de casos en los que es previsible que la gobernanza intersistémica resulte útil, de acuerdo con el análisis realizado aquí, son aquellos en los que las relaciones se ajustan a los denominados «juegos de coordinación". En este punto, mi análisis de la coordinación no ha puesto el énfasis en los juegos de coordinación en particular, sino en las dinámicas de coordinación en general. Es muy probable, no obstante, que los regímenes de gobernanza intersistémica sean especialmente efectivos donde los incentivos de los juegos de coordinación están presentes.

Las dinámicas de los juegos de coordinación se encuentran en el caso proverbial de "tratar de encontrar a un amigo del que te has separado en Nueva York", en la decisión de "por qué lado de la carretera tienes que conducir", y en la selección de estándares técnicos ${ }^{229}$. En estos casos, a diferencia

228 De forma notable, esta es una cuestión importante, si uno ve el surgimiento de la gobernanza intersistémica como un proceso relativamente espontáneo, o como el resultado de una elección explícita relativa al diseño institucional. En cada caso, es importante saber qué factores hacen más o menos aplicable y efectiva la gobernanza intersistémica.

229 Vid., p. ej., SCHELLING, supra nota 7, en pág. 54-55. A modo de curiosidad, para los que están familiarizados con los famosos trabajos empíricos de Schelling, yo estaba sentado junto al reloj en la Estación Grand Central cuando escribía las frases anteriores. Como no era mediodía, sin embargo, no esperaba encontrar a nadie allí. 
del más tradicional del "dilema del prisionero", los jugadores no tienen incentivos para abandonar una determinada situación de equilibrio -óptima o menos óptima- que haya surgido ${ }^{230}$. Los incentivos del jugador, como tales, no son la cuestión, sino sus expectativas respecto al otro ${ }^{231}$.

Tal y como Richard McAdams ha demostrado empíricamente, la doctrina jurídica ha prestado una atención desigual al dilema del prisionero en el análisis de la actividad reguladora ${ }^{232}$. Y aún menos atención se ha prestado a las dinámicas de los juegos de coordinación y a los incentivos estratégicos, las ineficacias posibles, y el papel que potencialmente pueden jugar en el ámbito del derecho y la regulación. En los últimos años, sin embargo, esto ha empezado a cambiar, incluso en el estudio del derecho internacional ${ }^{233}$.

Desde un punto de vista crítico, cabe esperar que en los juegos de coordinación surjan modelos completamente distintos de ineficacia, más allá del que muestra el juego del dilema del prisionero. Para empezar, puede haber importantes barreras de entrada. Debido a la tendencia de los mercados caracterizados por una gran demanda de coordinación de "inclinarse" por un estándar dominante, los jugadores pueden posponer su entrada, por miedo a elegir el caballo equivocado en una carrera que sea a todo o nada ${ }^{234}$. Una vez que se ha establecido el equilibrio de la coordinación, podemos observar un fuerte efecto de cierre. Dada la gran demanda de coordinación, los jugadores pueden no abandonar el equilibrio establecido, aunque éste pueda ser inferior al óptimo. ${ }^{235}$ Ellos pueden no estar dispuestos a arriesgarse a perder beneficios sustanciales de la red, incluso a cambio de un incremento en los beneficios "inherentes» a una elección estratégica dada ${ }^{236}$.

230 En el clásico dilema del prisionero, los conspiradores deben elegir estrategias individuales y colectivas no deseables. Cada uno de ellos sabe que recibirá una penalización mínima, si ambos se niegan a cooperar. Pero si uno permanece en silencio, mientras el otro confiesa, el primero recibirá una penalización mayor, y "la rata" nada en absoluto. Si ambos confiesan, en cambio, los dos recibirán una penalización moderada. Así pues, de acuerdo con lo que nos enseña el dilema del prisionero, el último es el resultado más probable - a pesar de su inferioridad individual y colectiva respecto al resultado posible si ambos hubieran permanecido en silencio. Vid. AHDIEH, supra nota 7, en pág. 229-30.

231 Vid. supra notas 183-84 y el texto que las acompaña.

232 Vid. MCADAMS, supra nota 183, en pág. 1654-55; Richard H. MCADAMS, Beyond the Prisoners' Dilemma: Coordination, Game Theory, and Law, 82 S. Cal. L. Rev. (forthcoming 2009); vid. también Ahdieh, supra nota 7, en pág. 229-30. Para ser claros, yo no pretendo sugerir que el análisis del dilema del prisionero no sea importante en el análisis del derecho internacional -o del derecho y la regulación en general-. Yo simplemente señalo que los juegos de coordinación pueden no ser menos importantes, en parte debido a su naturaleza auto-impositiva —el factor que realmente ha hecho que los juristas no les presten atención-

233 Vid., p. ej., Paul B. STEPHAN, What Story Got Wrong-Federalism, Localist Opportunism, and International Law, 73 Mo. L. Rev. 1041 (2008); cfr. Curtis A. BRADLEY, The Treaty Power and American Federalism, 97 Mich. L. Rev. 390, 459-60 (1998) (que apunta el "cambio de la costumbre al código" en el derecho internacional).

234 Vid. supra nota 181.

235 Vid. supra notas 180-82 y el texto que las acompaña.

236 Vid. AHDIEH, supra nota 7, en pág. 291-92. 
En estos casos, los regímenes de gobernanza intersistémica pueden desempeñar un papel beneficioso. Como se ha descrito, un rasgo importante de estos regímenes es el rol creciente de la persuasión -incluso retórico- en las operaciones de derecho y regulación ${ }^{237}$. Una persuasión de este tipo es, en cierto sentido, el mecanismo esencial por el cual las expectativas pueden modificarse de modo que mitiguen los fallos de coordinación. Más claramente, los regímenes de gobernanza intersistémica pueden ofrecer una superestructura con mayor capacidad, permitiendo una coordinación más efectiva de todo el universo de participantes en el juego de coordinación.

Más allá de los casos caracterizados por los resultados de los juegos de coordinación, se pueden identificar otros indicadores que incrementan la posibilidad de que la gobernanza intersistémica se establezca y constituya un esquema efectivo de derecho y regulación. Aunque un estudio detallado de estos factores nos llevaría más allá de los objetivos de este trabajo, es útil hacer aquí una referencia breve de todos ellos en orden a establecer una gradación en la aplicabilidad de la gobernanza intersistémica ${ }^{238}$.

De entrada, un contexto institucional estable en términos generales puede ser importante para el surgimiento y funcionamiento de la gobernanza intersistémica $^{239}$. Para los participantes en estos regímenes, la continuidad puede tener su correspondencia con el compromiso - y quizás el capital político- que están dispuestos a adquirir. En esencia, si el objetivo, que ya de por sí supone un desafío, del compromiso entre autoridades reguladoras de ámbitos competenciales solapados se caracteriza por la ambigüedad sobre quiénes son los homólogos reguladores con los que se va a actuar, entonces el esfuerzo no merecerá la pena.

Otras dos facetas de la interacción que se produce más allá de los límites de los ámbitos competenciales correspondientes pueden también incrementar las posibilidades de la gobernanza intersistémica. La primera es cierta recurrencia o repetición en la interacción ${ }^{240}$. Cuanto mayores sean las ocasiones para actuar, más posibilidades habrá de establecer ciertos modelos —y quizás un modelo de gobernanza intersistémica en particular-. De acuerdo con lo anterior, cuanto más fácilmente evidente sea la reciprocidad en esas interacciones, más probabilidades de viabilidad tendrá la gobernanza intersistémica. En suma, cuanto más se manifieste la interdependencia señalada anteriormente en formas recíprocas visibles - formas en las que todos ganan, si se quiere- mayores serán las posibilidades de establecer un sistema de gobernanza de este tipo.

Otro indicador de la eficacia de la gobernanza intersistémica se refiere a los valores de los participantes en la misma - y específicamente al grado de

237 Vid. supra notas 172-74 y el texto que las acompaña.

238 En trabajos anteriores he explorado con más detalle algunos de esos elementos. Vid. AHDIEH, supra nota 77, en pág. 911-14; AHDIEH, supra nota 143.

239 Cfr. AHDIEH, supra nota 143, en pág. 2099-101.

240 Vid. id. en pág. 2097-99. 
variedad de esos valores- ${ }^{241}$ Probablemente, cierto grado de alineamiento en lo que yo he denominado las "perspectivas" de las instituciones reguladoras participantes es esencial para que simplemente se acepte la gobernanza intersistémica. Por otra parte, ese alineamiento puede resultar excesivo. Precisamente en esos casos en los que las perspectivas de los implicados son divergentes, la gobernanza intersistémica es especialmente útil ${ }^{242}$. En ellos, los modelos jerárquicos de actuación pueden resultar demasiado rígidos. Por el contrario, el "toma y daca" y la flexibilidad inherente - el "margen de apreciación»- de la gobernanza intersistémica pueden funcionar bien. Como se ha descrito anteriormente, es precisamente en estos casos donde la gobernanza intersistémica puede ofrecer un mecanismo no invasivo para fomentar un mayor alineamiento de valores.

La naturaleza del área de regulación también influye en que la gobernanza intersistémica sea más o menos viable y efectiva. Para empezar, ésta puede ser más apropiada en aquellas áreas en las que el interés por la responsabilidad y la finalidad sean relativamente poco importantes ${ }^{243}$. La importancia política de una determinada cuestión y el grado en el que haya desacuerdo sobre ella dentro de un ámbito competencial determinado pueden ser, así, factores importantes a tener en cuenta cuando se valore el posible rol de la gobernanza intersistémica. Otro factor puede ser el grado de falta de certeza o inseguridad vinculado a una regulación en un área determinada. Cuando mayor sea el grado de inseguridad, más puede verse la gobernanza intersistémica como un modelo apropiado - en cierto sentido, porque resuelve cuestiones— ${ }^{244}$. De forma similar, esta gobernanza puede ser relativamente más fácil de aceptar allí donde las cuestiones a resolver no se considera que exijan una especialización concreta ${ }^{245}$. Si esto ocurre, es más probable que se entienda que la competencia compartida entre diversas autoridades es contraria a la especialización de cualquier régimen regulador de que se trate, siempre que se considere que éste es el más especializado.

En sentido contrario, las materias relacionadas con la relevancia de información especializada para la regulación en un área determinada pueden llevarnos en la dirección opuesta ${ }^{246}$. Cuanto más central sea la información para la regulación de un ámbito determinado, más posibilidades existen de que la superposición que caracteriza a la gobernanza intersistémica pueda considerarse que cumple una función beneficiosa. Si la información es la llave, entonces puede preferirse que existan múltiples mecanismos que la generen.

Finalmente, hay un conjunto de factores que pueden jugar tanto a favor como en contra, respecto a la relevancia y la eficacia de la gobernanza inter-

241 Vid. AHDIEH, supra nota 77, en pág. 912-13.

242 Vid. AHDIEH, supra nota 143, en pág. 2095-97.

243 Vid. AHDIEH, supra nota 77, en pág. 911.

244 Vid. id. en pág. 913.

245 Vid. id. en pág. 911.

246 Vid. id. en pág. 912. 
sistémica. En primer lugar, el número. Cuanto mayor sea el número de participantes, más difícil será lograr la coordinación. Aunque, por otro lado, cuanto más difícil sea la coordinación, más se considerará que los esquemas institucionalizados de interacción, como el de la gobernanza intersistémica, juegan un papel beneficioso. Se puede imaginar un tamaño de grupo ideal para maximizar la eficacia de la gobernanza intersistémica, con el número justo de participantes, ni muchos ni pocos.

Un análisis similar puede realizarse respecto a la importancia de la protección específica de los derechos individuales en un área determinada del derecho ${ }^{247}$. Los regímenes jerárquicos pueden considerarse relativamente más amenazantes para estos derechos, lo cual hace que se dirija más la atención hacia la gobernanza intersistémica. Sin embargo, por otro lado, ésta genera sus propias amenazas, como la ambigüedad o la falta de atención. Además, como se ha explicado ya, este tipo de gobernanza puede ser poco adecuada desde el punto de vista del universalismo que tradicionalmente ha caracterizado nuestra concepción de los derechos individuales.

Por último, el contexto socio-cultural correspondiente puede asimismo actuar a favor o en contra de la gobernanza intersistémica de formas diferentes $^{248}$. De entrada, una cultura en la que el concepto de soberanía esté muy arraigado, tanto en general como en relación a una materia concreta, puede hacer más difícil la viabilidad de la gobernanza intersistémica. En relación con esto, la existencia de instituciones nacionales fuertes puede producir, tanto una mayor resistencia a esta forma de gobernanza - si fomentan un sentimiento de autosuficiencia y aislamiento desde el punto de vista de su competencia-, como una menor resistencia — si estas instituciones promueven más la interdependencia que caracteriza a la gobernanza intersistémica-.

También cabe imaginarse una dinámica en la que las instituciones políticas de un ámbito determinado establezcan vínculos con instituciones exteriores como forma de lograr influencia ${ }^{249}$. Esto puede observarse en el funcionamiento de las redes subnacionales descrito anteriormente. Igualmente, eso es lo que caracteriza el compromiso de los tribunales nacionales inferiores con los tribunales supranacionales en Europa, lo que contribuye a que la Unión Europea sea como la conocemos hoy en día ${ }^{250}$. En estos casos, la gobernanza intersistémica surge en economías políticas que no son puestas en tela de juicio en los ámbitos jurisdiccionales participantes. Dinámicas políticas similares dentro de otros ámbitos competenciales pueden ser del mismo modo un impulso para la gobernanza intersistémica.

247 Vid. id. en pág. 911-12.

248 Vid. id. en pág. 913-14.

249 Vid. id. en pág. 914.

$250 \mathrm{Vid}$. Karen J. ALTER, Establishing the supremacy of european law: the making of an international rule of law in Europe 47-50 (2001). 


\section{V.3. LOS PELIGROS DE LA GOBERNANZA INTERSISTÉMICA}

Para terminar, algo debemos decir sobre los peligros de la gobernanza intersistémica. ¿Qué es lo negativo de la superposición y la interdependencia que caracterizan a estos regímenes? Teniendo en cuenta la larga resistencia que se ha opuesto a estos modelos ¿cuáles son sus desventajas?

En principio, debemos señalar las críticas tradicionales que, no obstante, la gobernanza intersistémica ha superado. En los últimos años, se ha convertido en una rutina criticar cualquier aplicación nacional de normas internacionales por considerarse contraria a los principios esenciales de soberanía, democracia y federalismo ${ }^{251}$. La explicación ofrecida aquí, no obstante, acalla completamente esta crítica ${ }^{252}$.

Los procesos antes descritos son fundamentalmente democráticos. Las normas internacionales se incorporan al ordenamiento interno, no a través de instituciones judiciales que no actúan conforme al principio mayoritario, sino a través de iniciativas políticas. El modelo de participación subnacional que constituye el núcleo del presente trabajo surge de la iniciativa de poderes políticos - legislativos y ejecutivos estatales y locales- de comprometerse en materia de asuntos exteriores y derecho internacional. Como tal, esto es completamente democrático ${ }^{253}$.

De otro lado, puesto que la iniciativa política es de carácter estatal o local, la crítica a la internacionalización basada en argumentos relativos al principio federal es del mismo modo inapropiada. Cualquier incorporación nacional de normas internacionales se produce, en este caso, en el nivel subnacional, en línea con lo exigido por el federalismo. De hecho, si se admite que el derecho internacional puede crear cada vez más oportunidades para que las autoridades subnacionales sean escuchadas — de dar voz a los estados y entes locales-, entonces la internacionalización no sólo sería conforme con el federalismo, sino que supondría además un impulso para el mismo.

Por otra parte, es evidente que la gobernanza intersistémica tiene sus límites. Allí donde no se den diversos de los factores señalados en el apartado anterior, esta forma de gobernanza será poco apropiada. Si existe sólo una interacción puntual, que afecte a materias en las que la necesidad de información no sea especialmente intensa, respecto a las cuales los valores varían radicalmente de unos ámbitos competenciales a otros, entonces la gobernanza intersistémica seguramente resultará fuera de lugar.

Más claramente, la gobernanza intersistémica —con su reiteración y mayor calidad- puede resultar menos efectiva en situaciones de crisis. En estos casos pueden estar realmente justificados los modelos jerárquicos de relacio-

251 Vid. supra nota 35 y el texto que la acompaña.

252 Los modelos que yo señalo aquí pueden compararse con los "portales normativos" identificados por Peggy McGuinness como vehículos para la internacionalización nacional de normas internacionales. Vid. MCGUINNESS, supra nota 112.

253 Vid. id. en pág. 839; cfr. BERMAN, supra nota 11, en pág. 1183-84. 
nes entre distintos entes con ámbitos competenciales superpuestos; y puede ser que la explicación del "caos" respecto al compromiso subnacional en materia de asuntos exteriores - y a la gobernanza intersistémica en generalresulte totalmente adecuada ${ }^{254}$.

En relación con lo anterior, esta forma de gobernanza puede ser criticada por generar una falta de certeza o inseguridad creciente. La predecibilidad del derecho disminuye cuando son varios los entes reguladores con poder para decidir en relación a una determinada materia. Así, si dos ámbitos competenciales pueden actuar en una cuestión concreta, y tienen diferentes perspectivas o posiciones al respecto, la inseguridad con la que se encuentra el sujeto regulado es necesariamente grande ${ }^{255}$. Si mi explicación de la gobernanza intersistémica como fuente de innovación es acertada, entonces esa inseguridad es aún mayor ${ }^{256}$. En un régimen de gobernanza de este tipo, cada ámbito competencial es más capaz de innovar y modificar. Naturalmente, el grado de esta falta de certeza - y su significado- probablemente varíe según el contexto material e institucional. Pero en algunos contextos, ésta constituye un defecto importante de la gobernanza intersistémica.

Habrá quien considere que precisamente el ámbito de los asuntos exteriores y el derecho internacional es un contexto de ese tipo. Así, la dificultad de algunas instituciones extranjeras para identificar a un único interlocutor en los Estados Unidos, al haberse incrementado las voces subnacionales-, es un ejemplo perfecto de esa falta de certeza. En los últimos años, algunos Estados extranjeros, por ejemplo, han dudado sobre si extraditar a sospechosos penales, dada la ambigüedad respecto a que las autoridades nacionales puedan comprometerse a asegurar de forma autoritaria la exclusión de la pena de muerte ${ }^{257}$. Con una capacidad creciente de los Estados extranjeros para actuar por desquite contra autoridades subnacionales, como se ha descrito anteriormente, parte de ese interés puede disminuir ${ }^{258}$. Lo mismo podría decirse donde exista un régimen nacional de coordinación horizontal fuerte. A pesar de ello, la inseguridad inherente a la gobernanza intersistémica es real y constituye un factor que aconseja su no utilización en determinados casos.

También debemos señalar otras limitaciones de la gobernanza intersistémica. Como hemos explicado ya, no debe entenderse que este tipo de go-

254 Por otra parte, que esto sea la interpretación tradicional no debe hacer que la admitamos demasiado rápidamente. Como Deborah Pearlstein ha argumentado de forma similar en relación a cuestiones de seguridad nacional, puede haber poca base para la opinión extendida de que la concentración en el poder ejecutivo de la potestad de decidir en casos de emergencia produce un efecto positivo. Vid. Deborah PEARLSTEIN, The Constitution and Executive Competence in the Post-Cold War World, 38 Colum. Hum. Rts. L. Rev. 547 (2007).

255 La posibilidad de elegir estratégicamente una jurisdicción puede considerarse como una faceta de esa inseguridad.

256 Vid. supra notas 224-27 y el texto que las acompaña.

257 Vid. Michael J. KELLY, Cheating Justice by Cheating Death: The Doctrinal Collision for Prosecuting Foreign Terrorists-Passage of Aut Dedere Aut Judicare into Customary Law \& Refusal to Extradite Based on the Death Penalty, 20 Ariz. J. Int'l \& Comp. L. 491, 518 (2003).

258 Vid. supra nota 117 y el texto que la acompaña. 
bernanza asegura invariablemente el logro de los fines materiales deseados ${ }^{259}$. De hecho, cuanto mayor sea el compromiso con un determinado fin, más problemática resultará la gobernanza intersistémica. Así, por ejemplo, en el ámbito de los derechos humanos, el pluralismo implícito en esta forma de gobernanza puede no ser un beneficio que aconseje la adopción de un régimen de este tipo, sino un peligro que haya que evitar. Desde una perspectiva más amplia, la aceptación de múltiples voces — casi por necesidad- puede hacer esperar que sea posible superar la falta de acuerdo con la opinión definida de un participante concreto o incluso con la opinión de la mayoría. En cierto sentido, este es el elemento esencial de la gobernanza intersistémica. Los compromisos procesales de esta forma de gobernanza imponen algunas concesiones a compromisos universales o a otro tipo de compromisos sustantivos en calidad de fines. Así, estas concesiones pueden favorecer la gobernanza intersistémica en algunos casos, mientras que en otros pueden resultar negativas.

Finalmente, a pesar de la utilidad procesal que pueda ofrecer, la redundancia característica de estos regímenes de gobernanza también es un motivo de ineficiencia procesal. Los procesos de toma de decisiones que se repiten pueden compararse con los sistemas repetitivos de procesamiento electrónico de datos, de comunicación a larga distancia, de generación de energía y otros similares. Estos últimos son mecanismos de seguridad que exigen un mantenimiento constante y sirven a sus funciones sólo episódicamente. Naturalmente el ejemplo no es exactamente el mismo en el contexto técnico que en el jurídico-político. Pero es muy gráfico: los mecanismos redundantes de gobernanza comparten parte de su ineficacia con estas tecnologías. En todo caso, es necesario y adecuado el análisis de los beneficios de la gobernanza intersistémica en un contexto concreto. Y, al menos en algunas ocasiones, como es obvio, ese análisis de costes-beneficios concluirá que es preciso evitar la redundancia.

\section{CONCLUSIONES}

El análisis que hemos realizado pone de manifiesto, como poco, la necesidad de repensar la naturaleza del federalismo. Y ello vale tanto para los críticos del federalismo como para sus defensores. Frente a los primeros, la coordinación horizontal se presenta como un elemento determinante. La expansión del federalismo, y la emergencia de nuevas voces resultante, no tiene necesariamente que tener implicaciones negativas de cara a nuestra capacidad para coordinarnos. Una coordinación eficiente es posible tanto en un sistema unitario como en uno federal, incluso si se atribuyen competencias decisoras importantes en asuntos exteriores y derecho internacional a las

259 Apoyar la coordinación, como tal, permite discutir las normas sustantivas en juego. Vid. supra notas 214-215 y el texto que las acompaña. 
autoridades nacionales y a las subnacionales. A lo largo de casi todo - si no todo- el espectro que va desde la competencia exclusiva nacional a la competencia exclusiva subnacional, la coordinación puede buscarse y lograrse.

Para los defensores del federalismo, el análisis anterior aconseja ciertas precauciones respecto a lo que se puede esperar que consiga un sistema federal. Según ellos, entre los más significativos elementos positivos de un sistema así se encuentran el fortalecimiento de la diversidad y el pluralismo, y el fomento de una competencia que conduce a una mayor eficacia ${ }^{260}$. Sin embargo, un gran pluralismo y una dinámica de competencia entre distintos ámbitos de organización son posibles resultados del federalismo, pero no necesariamente derivan de él en todos los casos. Así, algunos de los más entusiastas defensores del federalismo se resisten a los paradigmas de la coordinación horizontal - lo que ellos suelen llamar con cierta ironía "federalismo cooperativo"— ${ }^{261}$. Más bien, éstos se adhieren a un modelo concreto de federalismo - "el federalismo competitivo"-, en el que los entes subnacionales compiten unos con otros. Sin embargo, los ejemplos de la coordinación horizontal aquí expuestos evidencian que el pluralismo y la competencia están lejos de ser elementos inherentes a la atribución de competencias de decisión política a los Estados que integran una federación o a los entes locales.

Desde una perspectiva más amplia, el análisis realizado en este trabajo aconseja reconsiderar la tradicional concepción de las relaciones entre instituciones e intereses nacionales, subnacionales e internacionales. El análisis de la coordinación que hemos ofrecido puede ayudar a valorar el que se ha descrito como "declinar" del Estado-nación. Es cierto que el gobierno nacional ya no ocupa un lugar tan central en la dinámica de las relaciones subnacionales, nacionales e internacionales. La coordinación internamente dirigida, establecida al servicio de la coordinación externamente dirigida, puede abarcar cada vez menos lo que sucede realmente en el mundo. Por otro lado, esto no tiene por qué significar la desaparición del Estado-nación, sino, como mucho, una disminución de su tamaño en la economía política de las relaciones subnacionales, nacionales e internacionales. Cada vez más los gobiernos nacionales serán uno entre iguales —y, quizás, aún los primeros entre iguales- pero no el exclusivo punto de apoyo para la toma de decisiones. Sin embargo, no desaparecerán. De hecho, es muy posible que se incrementen ciertas formas de autoridad nacional —allí donde el gobierno nacional ayude a lograr modelos de coordinación horizontal— ${ }^{262}$.

De forma relevante, el análisis realizado ofrece un esquema para el avance de la participación sistemática de los entes subnacionales en materia de

260 Vid. John O. MCGINNIS \& Ilya SOMIN, Federalism vs. States' Rights: A Defense of Judicial Review in a Federal System, 99 Nw. U. L. Rev. 89, 112 (2004); vid. también Edward L. RUBIN \& Malcolm FEELEY, Federalism: Some Notes on a National Neurosis, 41 Ucla L. Rev. 903, 914-15 (1994).

261 Vid., p. ej., Michael S. GREVE, Against Cooperative Federalism, 70 MISS. L.J. 557 (2000).

262 Vid. supra Parte IV.2. 
asuntos exteriores y derecho internacional. Contrariamente a las ideas tradicionales, no hay motivo para evitar la intervención de Estados federados y entes locales en esta materia. En consecuencia, no plantean mayor problema las iniciativas para promover las relaciones horizontales en orden a maximizar la eficacia de la participación estatal y local ${ }^{263}$. Cuando se haya establecido una coordinación horizontal de este tipo, es posible esperar que surja una nueva dinámica de gobernanza intersistémica, en la que instituciones subnacionales, nacionales e internacionales ejerzan competencias que se superpongan o solapen y desarrollen una interdependencia que probablemente determine la aparición de nuevos modelos de derecho y regulación.

Todo esto lleva a una conclusión final, la necesidad de prestar mayor atención a las cuestiones de diseño institucional en la relación entre autoridades subnacionales, nacionales e internacionales. El paradigma del federalismo dual en un Estado tipo Westfalia, aunque haya podido ofrecer alguna vez cierta utilidad, ya no es el apropiado. Es necesario reconsiderar nuestra explicación estándar tanto de la gobernanza nacional como transnacional. El Estado nación puede no estar desapareciendo y el Gobierno Mundial puede no estar esperando una oportunidad para entrar en escena. Sin embargo, los cambios en la naturaleza de ambas gobernanzas, la nacional y la trasnacional, están en marcha, y exigen nuestra atención. Al valorar las instituciones de gobierno existentes y diseñar otras nuevas, haremos bien en tener en cuenta los cambios en las dinámicas de coordinación en las relaciones subnacionales, nacionales e internacionales.

TitLE: Foreign Affairs, International Law, and the New Federalism: Lessons from coordination.

ABSTRACT. Even after the departure of two of its most prominent advocates - Chief Justice William Rehnquist and Justice Sandra Day O'Connor - the federalism revolution initiated by the Supreme Court almost twenty years ago continues its onward advance and it may have reached a new beachbead in the realm of foreign affairs and international law. The emerging federalism in this realm is of a distinct form, however, with distinct implications for the relationship of subnational, national, and international institutions and interests. This article draws on the prism of "coordination," as well as related analysis of standard-setting, to question two conventional assumptions about the relationship of sub-national, national, and international institutions: the common notion that a coherent foreign affairs regime requires "one voice" to speak for the nation and the perception of some inherent conflict in the interaction of international norms and subnational interests. Both these claims are wrong. Coordination can be achieved in foreign affairs even with multiple voices. International law, meanwhile, may increasingly offer opportunities for states and localities to be heard. Once we appreciate as much, we can begin to develop a richer account of the interaction of sub-national, national, and international institutions, as "our federalism" reaches abroad.

263 Entendidas como esfuerzos para integrar las voces subnacionales de forma más general. Vid. RESNIK, supra nota 75, en pág. 1112-13. 
RESUMEN: Incluso después de la partida de dos de sus más prominentes defensores - los Jueces William Rehnquist y Sandra Day O'Connor - la revolución del federalismo iniciada por el Tribunal Supremo casi hace veinte años continúa avanzando y puede haber alcanzado una nueva cabeza de playa en el campo de los asuntos exteriores y el derecho internacional. El federalismo emergente en este campo adopta, sin embargo, una forma distinta, con claras implicaciones para la relación entre los intereses y las instituciones subnacionales, nacionales e internacionales. Este artículo se sirve del prisma de la "coordinación", así como del análisis de las teorías sobre el establecimiento de estándares, para poner en tela de juicio dos creencias convencionales sobre la relación entre las instituciones subnacionales, nacionales e internacionales: la idea común de que un régimen coherente de asuntos exteriores exige que sea" una voz" la que bable por la nación y la percepción de que existe un conflicto inherente a la interacción de las normas internacionales y los intereses subnacionales. Ambas ideas son erróneas. Es posible lograr la coordinación en el ámbito de los asuntos exteriores aun con voces múltiples. El derecho internacional, por otro lado, puede ofrecer a los Estados federados y a las entidades locales la oportunidad de ser oídos. Una vez que nos damos cuenta de que así es, podemos empezar a desarrollar una explicación más rica de la interacción de las instituciones subnacionales, nacionales e internacionales, a medida que "nuestro federalismo" se proyecta en el extranjero.

KeY WORDS: New Federalism. Horizontal Coordination. Intersistemic Governance. Subnational Engagement in Foreign Affairs. Networks of States and Localities.

Palabras clave: Nuevo federalismo. Coordinación horizontal. Gobernanza intersistémica. Participación subnacional en asuntos exteriores. Redes de estados federados y entes locales. 